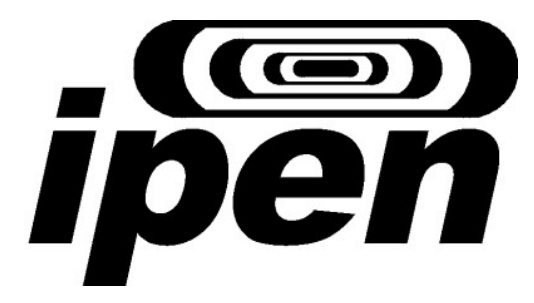

\begin{abstract}
INSTITUTO DE PESQUISAS ENERGÉTICAS E NUCLEARES
AUTARQUIA ASSOCIADA À UNIVERSIDADE DE SÃO PAULO
\end{abstract}

SÍNTESE E PROCESSAMENTO DE COMPÓSITOS À BASE DE ALUMINA E ZIRCÔNIA COM INFILTRAÇÃO DE FASE VÍTREA

PARA APLICAÇÕES ODONTOLÓGICAS

DANIEL GOMES DUARTE

Dissertação apresentada como parte dos requisitos para obtenção do Grau de Mestre em Ciências na Área de Tecnologia Nuclear - Materiais.

Orientadora:

Dra. Dolores Ribeiro Ricci Lazar 
INSTITUTO DE PESQUISAS ENERGÉTICAS E NUCLEARES AUTARQUIA ASSOCIADA À UNIVERSIDADE DE SÃO PAULO

SÍNTESE E PROCESSAMENTO DE COMPÓSITOS À BASE DE ALUMINA E ZIRCÔNIA COM INFILTRAÇÃO DE FASE VÍTREA

PARA APLICAÇÕES ODONTOLÓGICAS

DANIEL GOMES DUARTE

Dissertação apresentada como parte dos requisitos para obtenção do Grau de Mestre em Ciências na Área de Tecnologia Nuclear - Materiais.

Orientadora:

Dra. Dolores Ribeiro Ricci Lazar 
Áqueles que mais ano, exemplos de vida, educadores e maiores incentivadores: mens Pais, Floventina e Gosé Carlos.

Ao irmão e maior amigo, Samuel, de personalidade inica e grande incentivador. 


\section{AGRADECIMENTOS}

Ao Instituto de Pesquisas Energéticas e Nucleares, pela oportunidade de desenvolver este trabalho.

À Coordenação de Aperfeiçoamento de Pessoal de Nível Superior (CAPES), pela bolsa de estudos concedida, imprescindível para a realização deste trabalho.

À Dra. Dolores Ribeiro Ricci Lazar, pelo voto de confiança e oportunidade de ampliação e complementação dos conhecimentos por mim adquiridos durante a graduação em Odontologia, em uma nova e tão fascinante área como a Ciência dos Materiais, aceitando a difícil tarefa de orientação neste trabalho e sempre prezando por uma sólida formação, com notória paciência, liberdade para trabalhar e compreensão, sem as quais este trabalho não seria possível.

Ao Dr. Maximiliano Piero Neisser, o bom amigo e "orientador" Max, dotado de tão jovial e experiente alma, pelos cafés e conversas agradabilíssimas que em muito me engrandecem academicamente e como pessoa.

Aos Drs. Igor Studart Medeiros e Paulo Francisco Cesar, exemplos acadêmicos e pessoais, pelo incentivo e acolhida.

Aos docentes com os quais cruzei desde a graduação, pelo exemplo a ser ou não seguido e conhecimentos que adquiri.

A todos os companheiros do CCTM, já mestres, doutores ou não, pela descontração, ajuda no desenvolvimento experimental, suporte e contribuição singular que cada um teve nessa etapa de minha vida acadêmica.

Ao companheiro de labuta, Msc. Leonardo de Paulo Santana, pela acolhida quando ainda engatinhava no deslumbrante mundo da Ciência dos Materiais e pelas constantes discussões e divertidíssimas conversas. 
Ao Bel Walter Kenji Yoshito, pelos imprescindíveis ensinamentos e contribuições durante a realização do experimental, bem como pelo excelente convívio e divertidas conversas.

Ao recém colega e companheiro de mestrado, Alexander Rodrigo Arakaki, dono de um raciocínio e tranqüilidade invejáveis, pelo prazeroso convívio e pela mãozinha na parte experimental - literalmente falando - sem a qual este trabalho não seria finalizado.

Aos colegas Celso V. de Moraes, Nildemar A. M. Ferreira e Glauson A. F. Machado, pela caracterização microestrutural por microscopia eletrônica de varredura e de transmissão e pelo convívio bastante harmonioso.

Aos colegas Dr. Nelson B. de Lima e Rene R. de Oliveira, pela presteza e dedicação nas análises por Difraçãos de raios $X$, excelente acolhida $e$ maravilhoso convívio.

Ao Dr. José Roberto Martinelli, pela realização das análises granulométricas.

À Dra. Eliana Aricó do Centro de Células a Combustível e Hidrogênio $\mathrm{CCCH}$, pela realização das análises termogravimétricas e de dilatometria.

À Dra. Vera Lucia Ribeiro Salvador e Dr. Marcos Scapin, pela realização das análises de fluorescência de raios $X$.

À Dra. Olga Zazuco Higa e Dra. Andréa Cecilia Dórion Rodas, pela realização dos ensaios de citotoxicidade.

À Dra. Ana Helena Bressiani, por disponibilizar a infraestrutura para a realização do ensaio de dureza. 
À Dra. Sonia Regina Homem de Mello Castanho e Dr. Antonio Carlos da Silva, pelo imprescindível auxilio na preparação do vidro utilizado na infiltração, bem como pelo excelente e prazeroso convívio e valorosos aconselhamentos.

Ao Dr. Luis Antonio Genova e Dr. Thomas Augusto Guisard Restivo, pela ajuda na interpretação dos dados de dilatometria, pelo prazeroso convívio e excelentes conversas.

À Joana D. de Andrade e Sandra M. Cunha, pelo bom convívio, auxílio laboratorial e manutenção do funcionamento da infraestrutura do laboratório de Insumos.

Aos familiares e amigos pelo apoio incondicional e pela compreensão dispensada quando de minhas ausências ou faltas.

A todos que direta ou indiretamente contribuíram para a realização deste trabalho.

A um novo olhar, sereno, que encontrei em meio à conturbada fase e que me traz conforto sem igual.

Às peculiaridades e inebriantes situações que vi, vivi e continuarei vivendo.

Ao que é maior do que tudo e me permite ser e estar aqui... 
"A água nunca discute com sens obstáculos, mas os contorna."

(Antor Desconhecido) 
"Saberse munto pouco, quando se sabe só o indispensável." (Voun Lave) 


\title{
SÍNTESE E PROCESSAMENTO DE COMPÓSITOS À BASE DE ALUMINA E ZIRCÔNIA COM INFILTRAÇÃO DE FASE VÍTREA PARA APLICAÇÕES ODONTOLÓGICAS
}

\author{
Daniel Gomes Duarte
}

\begin{abstract}
RESUMO
O interesse pelo emprego de materiais cerâmicos na odontologia surgiu, inicialmente, devido ao excelente resultado estético proporcionado pela similaridade aos dentes naturais. Entretanto, a fragilidade, inerente das cerâmicas tradicionais, era uma limitação que impossibilitava a utilização em condições em que o material fosse submetido à solicitação mecânica. Com o desenvolvimento de materiais à base de alumina e zircônia, os quais conciliam aspecto estético, biocompatibilidade e bom desempenho mecânico, o emprego de cerâmicas na fabricação de restaurações dentais começou a ser considerado. A incorporação de fase vítrea de reforço nestas cerâmicas tem como finalidade minimizar as taxas de retração e melhorar a adesão ao agente cimentante resinoso, necessário para união da infraestrutura cerâmica à estrutura dental remanescente. Comercialmente, esses materiais são conhecidos como sistemas InCeram ${ }^{\circledR}$. Considerando-se que o aprimoramento dos métodos de síntese e de técnicas de processamento de pós cerâmicos é um dos fatores fundamentais para o bom desempenho desses materiais, o presente trabalho teve como objetivo o estudo de obtenção de cerâmicas à base de alumina e/ou zircônia estabilizada com $3 \mathrm{~mol} \%$ de ítria com infiltração de fase vítrea de aluminoborossilicato de lantânio, partindo-se de insumos obtidos pela rota de coprecipitação de hidróxidos. Os pós sintetizados foram conformados por prensagem uniaxial e pré-sinterizados na faixa de temperatura entre 950 e $1650{ }^{\circ} \mathrm{C}$, visando a obtenção de corpos cerâmicos porosos. A incorporação da fase vítrea foi realizada pela impregnação do pó de aluminoborossilicato de lantânio, também preparado neste trabalho, e posterior tratamento térmico entre 1200 e $1400^{\circ} \mathrm{C}$. As técnicas empregadas para caracterização dos pós incluíram: termogravimetria, difração de raios $X$, microscopia eletrônica de varredura e de transmissão, adsorção gasosa (BET) e espalhamento a laser. A sinterabilidade das amostras compactadas de alumina e/ou zircônia foi avaliada por dilatometria. As cerâmicas pré-sinterizadas foram avaliadas por medidas de densidade aparente pelo princípio de Archimedes, difração de raios $X$ e observação da microestrutura por microscopia eletrônica de varredura. Testes de impressão Vickers e de citotoxicidade foram realizados após incorporação da fase vítrea. Tendo em vista a integridade estrutural, homogeneidade da microestrutura, elevados valores de tenacidade à fratura $\left(3,6-4,9 \mathrm{MPa} \cdot \mathrm{m}^{1 / 2}\right)$ e a não citotoxicidade dos materiais preparados, constatou-se, neste trabalho, que as cerâmicas à base de alumina preparadas a partir de pós coprecipitados, são adequadas para obtenção de infraestruturas dentais com infiltração com fase vítrea.
\end{abstract}




\title{
SYNTHESIS AND CERAMIC PROCESSING OF ALUMINA AND ZIRCONIA BASED COMPOSITES INFILTRATED WITH GLASS PHASE FOR DENTAL APPLICATIONS
}

\author{
Daniel Gomes Duarte
}

\begin{abstract}
The interest for the use of ceramic materials for dental applications started due to the good aesthetic appearance promoted by the similarity to natural teeth. However, the fragility of traditional ceramics was a limitation for their use in stress conditions. The development of alumina and zirconia based materials, that associate aesthetic results, biocompatibility and good mechanical behaviour, makes possible the employment of ceramics for fabrication of dental restorations. The incorporation of vitreous phase in these ceramics is an alternative to minimize the ceramic retraction and to improve the adhesion to resin-based cements, necessary for the union of ceramic frameworks to the remaining dental structure. In the dentistry field, alumina and zirconia ceramic infiltrated with glassy phase are represented commercially by the In-Ceram® systems. Considering that the improvement of powder's synthesis routes and of techniques of ceramic processing contributes for good performance of these materials, the goal of the present work is the study of processing conditions of alumina and/or $3 \mathrm{~mol} \%$ yttria-stabilized zirconia ceramics infiltrated with aluminum borosilicate lanthanum glass. The powders, synthesized by hydroxide coprecipitation route, were pressed by uniaxial compaction and pre-sintered at temperature range between 950 and $1650^{\circ} \mathrm{C}$ in order to obtain porous ceramics bodies. Vitreous phase incorporation was performed by impregnation of aluminum borosilicate lanthanum powder, also prepared in this work, followed by heat treatment between 1200 and $1400^{\circ} \mathrm{C}$.Ceramic powders were characterized by thermogravimetry, X-ray diffraction, scanning and transmission electron microscopy, gaseous adsorption (BET) and laser diffraction. Sinterability of alumina and /or stabilized zirconia green pellets was evaluated by dilatometry. Pre-sintered ceramics were characterized by apparent density measurements (Archimedes method), X-ray diffraction and scanning electron microscopy. Vickers impression tests and citotoxicity essays were performed after glass phase incorporation. Considering the structural integrity of samples, homogeneity of microstrutures, high fracture toughness values $\left(3.6-4.9 \mathrm{MPa} \cdot \mathrm{m}^{1 / 2}\right)$ and no citotoxity effects, it was verified that alumina based ceramics, prepared from coprecipitated powders, are adequate for production of dental frameworks infiltrated by vitreous phase.
\end{abstract}




\section{SUMÁRIO}

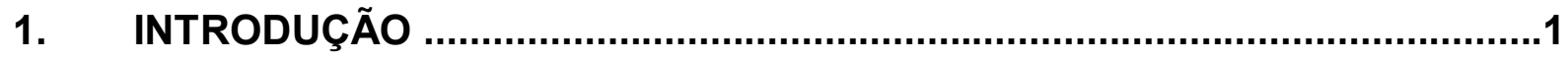

2. OBJETIVOS

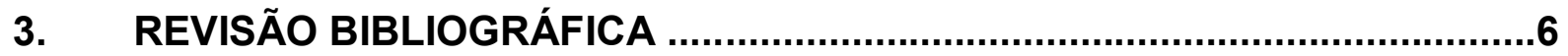

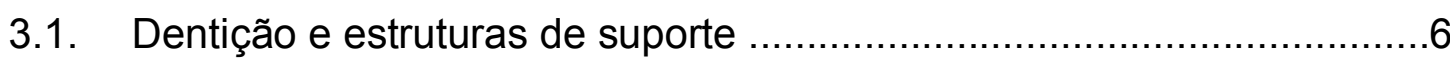

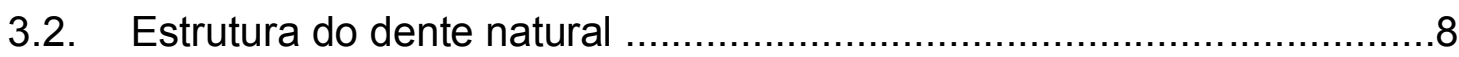

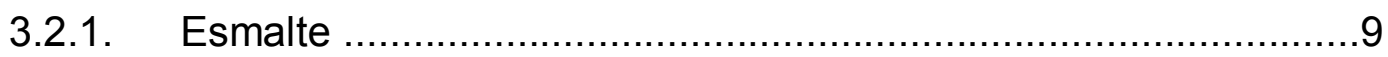

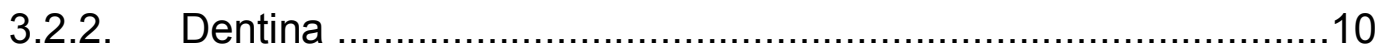

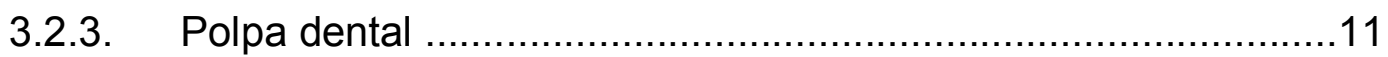

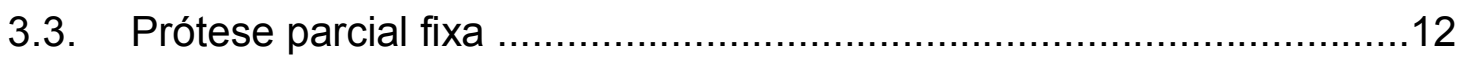

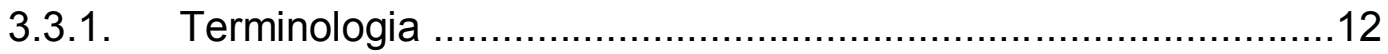

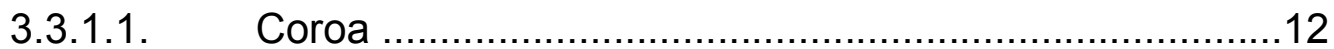

3.3.1.2. Restaurações intracoronárias fundidas ........................13

3.3.1.3. Faceta laminada de porcelana ......................................14

3.3.1.4. Prótese parcial fixa .................................................15

3.4. Histórico dos materiais aplicados em Odontologia ............................16

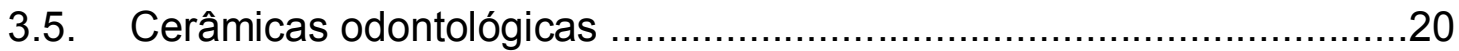


3.5.1. Cerâmicas odontológicas de cobertura ..................................24

3.5.2. Cerâmicas odontológicas para infraestrutura ..........................28

3.5.2.1. Cerâmicas à base de alumina .................................28

3.5.2.2. Cerâmicas de zircônia tetragonal policristalina ...............31

3.5.2.3. Cerâmicas infiltradas por vidro ...................................40

3.6. Tratamento de superfície da infraestrutura cerâmica ........................44

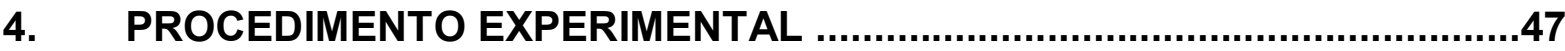

4.1. Síntese e processamento cerâmico .............................................47

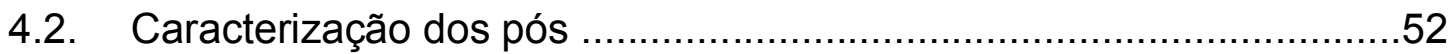

4.3. Processamento cerâmico .........................................................53

4.4 Caracterização dos corpos cerâmicos pré sinterizados e infiltrados por vidro

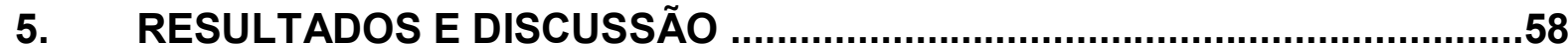

5.1. Caracterização dos hidróxidos secos .......................................58

5.2. Caracterização dos pós cerâmicos calcinados ..............................59

5.3. Caracterização das cerâmicas sinterizadas ..................................64

5.4. Síntese do vidro de aluminoborosilicato de lantânio ..........................71

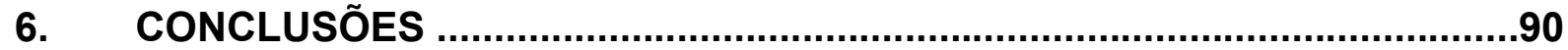


7. SUGESTÃO DE TRABALHOS ........................................................92

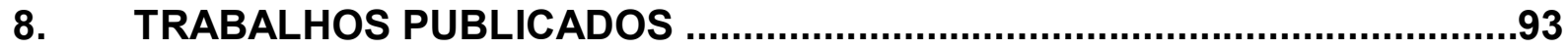

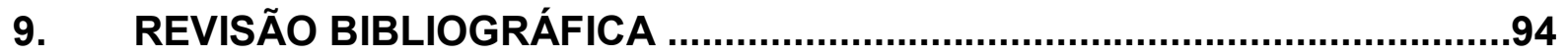




\section{LISTA DE TABELAS}

TABELA 3.1.1 - Características das forças normais exercidas sobre os dentes 7

TABELA 3.5.1 - Características de sistemas totalmente cerâmicos para próteses fixas 22

TABELA 3.5.2 - Materiais cerâmicos, denominações comerciais e técnicas de manufatura de alguns sistemas totalmente cerâmicos .23

TABELA 3.5.2.2.1 - Valores dos raios iônicos (R) e diferença (D) entre o tamanho do cátion dopante e o do $\mathrm{Zr}^{4+}$

TABELA 3.5.2.2.2 - Informaçãoes cristalográficas das estruturas polimórficas da zircônia

TABELA. 3.5.2.3.1 - Resumo das principais propriedades das cerâmicas odontológicas comerciais relativas ao sistema Vita In-Ceram

TABELA. 3.5.2.3.2 - Composição das fases vítreas relativas ao sistema Vita InCeram .43

TABELA 3.5.2.3.3 - Frações volumétricas das fases e porosidade que compõem as cerâmicas à base de alumina e zircônia com infiltração de fase vítrea conformadas por colagem de barbotinas e prensagem

TABELA 4.1.1 - Composição dos pós à base de alumina e zircônia, sintetizados pela rota de co-preciptação de hidróxidos

TABELA 4.1.2 - Composição da fase vítrea utilizada para infiltração no corpo poroso de alumina, zircônia estabilizada e compósito alumina-zircônia 
TABELA 4.1.3 - Composição das amostras cerâmicas à base de alumina e zircônia contendo fase vítrea de aluminoborossilicato de lantânio, preparadas neste trabalho .50

TABELA 5.2.1 - Área superficial específica dos pós sintetizados .60

TABELA 5.3.1 - Temperatura de máxima taxa de retração linear das cerâmicas de allumina $\theta$, de zircônia estabilizada e de compósitos de alumina-zircônia .....66 66

TABELA 5.3.2 - Densidade aparente das cerâmicas em função das condições de sinterização

TABELA 5.3.3. - Densidade aparente das cerâmicas em função das condições de sinterização .69

TABELA 5.3.4 - Densidade aparente das cerâmicas em função das condições de sinterização

TABELA 5.4.1. - Densidade aparente das cerâmicas contendo fase vítrea preparadas por infiltração ou mistura de pós .72

TABELA 5.4.2. - Coeficientes de expansão térmica dos materiais constituintes das cerâmicas odontológicas preparadas neste trabalho .75

TABELA 5.4.3. - Valores de dureza e tenacidade à fratura das cerâmicas à base de alumina e zircônia contendo fase vítrea de aluminoborossilicato de lantânio, de procedência comercial e preparadas neste trabalho .87 


\section{LISTA DE FIGURAS}

FIGURA 3.1.1 - Desenho esquemático dos dentes naturais vistos lateralmente ..7

FIGURA 3.2.1 - Ilustração de um dente molar em sua secção transversal .8

FIGURA 3.3.1.1 - Coroa total metalocerâmica 13

FIGURA 3.3.1.2 - Coroa parcial metálica 13

FIGURA 3.3.1.3 - (A) Inlay metália e (B) inlay cerâmica 14

FIGURA 3.3.1.4 - Onlay metálica 14

FIGURA 3.3.1.5 - Faceta laminada em cerâmica 15

FIGURA 3.3.1.6 - Componentes de uma prótese parcial fixa .16

FIGURA 3.5.2.1.1 - Empacotamento do íons Al e O no plano basal. A camada superior de íons $O$ não é mostrada. Vetores e direções da célula hexagonal estão indicados 30

FIGURA 3 5.2.1.2 - Infra-estruturas cerâmica para prótese unitária processada pela técnica slip casting 31

FIGURA 3.5.2.1.3 - Infra-estrura prensada para prótese parcial fixa de três elementos

FIGURA 3.5.2.2.1 - Diagrama de fases para o sistema $\mathrm{ZrO}_{2}-\mathrm{Y}_{2} \mathrm{O}_{3}$ .35

FIGURA 3.5.2.2.2 - Representação esquemática da formação de microtrincas ao redor de uma partícula de zircônia transformada (a) e a absorção da energia de uma trinca em propagação (b)

FIGURA 3.5.2.2.3 - Representação esquemática do mecanismo de transformação induzida por tensão 
FIGURA 3.5.2.2.4 - Modelo desenvolvido por Sato e colaboradores para explicar o comportamento de degradação da Y-TZP .39

FIGURA 3.5.2.2.5 - Modelo de degradação a baixas temperaturas de cerâmicas do sistema zircônia-ítria, proposto por Yoshimura: (a) adsorção química da água na superfície; (b) formação de ligações $\mathrm{Zr}-\mathrm{OH}$ e $\mathrm{Y}-\mathrm{OH}$ na superfície, criando pontos de tensão; (c) acúmulo de tensões pela migração de íons $\mathrm{OH}^{-}$na superfície e no retículo; e (d) nucleação da fase monoclínica nos grãos tetragonais, devido à área de deformação nucleada, causando a transformação $\mathrm{t} \rightarrow \mathrm{m}$ e a formação de micro e macro trincas

FIGURA 4.1.1 - Fluxograma esquemático da metodologia adotada para síntese, processamento e caracterização das cerâmicas à base de alumina e zircônia com infiltração de fase vítrea

FIGURA 4.4.1 - Desenho esquemático das trincas tipo Palmqvist e radial-mediana .56

FIGURA 5.1.1 - Curvas TG e DTA dos hidróxidos co-precipitados .59

FIGURA 5.2.1 - Distribuição granulométrica dos pós sintetizados .60

FIGURA 5.2.2. - Micrografias, obtidas por MEV, de pós de alumina calcinados a diferentes temperaturas: (a) $800^{\circ} \mathrm{C}$ por 1 hora; (b) $1200^{\circ} \mathrm{C}$ por 1 hora

FIGURA 5.2.3. - Micrografias, obtidas por MEV, de pós de zircônia estabilizada com ítria (a) e apresentando $70 \%$ em massa de alumina na composição (b) ......61 FIGURA 5.2.4. - Micrografias, obtidas por MET, de pós de alumina, zircônia estabilizada com ítria e compósito alumina-zircônia referentes às seguintes amostras: (a) AL; (b) AL- $\alpha$; (c) AL- $\alpha$ após moagem em moinho de alta energia; (d) Z3Y e (e) ALZ3Y

FIGURA 5.2.5. - Difratogramas de raios $X$ dos pós sintetizados .63

FIGURA 5.3.1. - Difratogramas de raios $X$ das cerâmicas sinterizadas a $1200^{\circ} \mathrm{C}$ por 1 hora .64

FIGURA 5.3.2. - Retração linear (a) e taxa de retração linear (b), em função da temperatura de sinterização das cerâmicas à base de alumina e zircônia .65 
FIGURA 5.3.3 - Porcentagem da densidade teórica (\%DT), em função da temperatura de sinterização das cerâmicas de alumina $\theta$, de zircônia estabilizada e compósito alumina-zircônia .66

FIGURA 5.3.4. - Micrografias, obtidas por MEV, de superfícies fraturadas de cerâmicas de alumina, sinterizadas a 1200 e $1300^{\circ} \mathrm{C}$ por 1 hora: (a) AL; (b) AL-a; do compósito cerâmico de alumina e zircônia estabilizada com ítria, sinterizada a $1200^{\circ} \mathrm{C}$ por 1 hora: (c) ALZ3Y; e, de zircônia estabilizada com ítria, sinterizada a $1200^{\circ} \mathrm{C}$ por 1 hora: (d) Z3Y

FIGURA 5.4.1. - Micrografia, obtida por MEV, do vidro de aluminoborosilicato de lantânio após moagem em moinho de bolas, por 5 horas, e desagregação em almofariz de ágata

FIGURA 5.4.2. - Micrografias, obtidas por MEV, de cerâmicas de zircônia estabilizada com $3 \mathrm{~mol} \%$ de ítria, calcinadas a $950^{\circ} \mathrm{C}$, pré sinterizadas a $1100^{\circ} \mathrm{C}$ por 1 hora e infiltradas com vidro a $1300^{\circ} \mathrm{C}$ por 2 horas: (a) uma infiltração, (b) duas infiltrações e (c) três infiltrações

FIGURA 5.4.3 - Fotografias das amostras de alumina infiltrada à $1100^{\circ} \mathrm{C}$ por 4 horas (a) e zircônia estabilizada com 3 mol\% de ítria infiltrada à $1300^{\circ} \mathrm{C}$ por 2 horas (b), submetidas à três infiltrações com fase vítrea de aluminoborossilicato de lantânio .74

FIGURA 5.4.4 - Micrografias, obtidas por MEV, das cerâmicas de alumina contendo fase vítrea de alumínioborossilicato de lantânio, mostrando a formação de porosidade durante o processamento: $(a-b)$ amostra $A L(i)$ e (c-d) amostra $\mathrm{AL}(\mathrm{m})$ 77

FIGURA 5.4.5 - Micrografia, obtida por MEV, e EDS da cerâmica de alumina infiltrada com fase vítrea de alumínioborossilicato de lantânio (amostra $A L(i))$...78 FIGURA 5.4.6 - Micrografia, obtida por MEV, e EDS da cerâmica de zircônia estabilizada infiltrada com fase vítrea de alumínioborossilicato de lantânio (amostra Z3Y (i))

FIGURA 5.4.7 - Micrografia, obtida por MEV, e EDS do compósito de aluminazircônia infiltrada com fase vítrea de alumínioborossilicato de lantânio (amostra ALZ3Y (i)). .80 
Figura 5.4.8 - Micrografia, obtida por MEV, e EDS da cerâmica de alumina impregnada com fase vítrea de alumínioborossilicato de lantânio, por mistura de pós (amostra $\mathrm{AL}(\mathrm{m})$ )

FIGURA 5.4.9 - Micrografia, obtida por MEV, e EDS da cerâmica de zircônia estabilizada impregnada com fase vítrea de alumínioborossilicato de lantânio, por mistura de pós (amostra Z3Y $(\mathrm{m})$ )

Figura 5.4.10 - Micrografia, obtida por MEV, e EDS do compósito de zircôniaalumina impregnado com fase vítrea de alumínioborossilicato de lantânio, por mistura de pós (amostra ALZ3Y $(\mathrm{m})$ )

Figura 5.4.11 - Difratogramas de raios $X$ das cerâmicas à base de alumina e zircônia após incorporação da fase vítrea (a) por impregnação e (b) por mistura de pós

Figura 5.4.12 -Micrografias, obtidas por microscopia ótica, de impressão Vickers em cerâmicas de alumina (a), alumina-zircônia (b) e zircônia estabilizada com 3 mol\% de ítria (c), submetidas à infiltração com fase vítrea de alumino borossilicato de lantânio .85

Figura 5.4.13 - Micrografias, obtidas por microscopia eletrônica de varredura, mostrando detalhes das indentações e trincas formadas nas cerâmicas infiltradas com fase vítrea, após ensaios de impressão Vickers: $(a-b)$ amostra $A L i ;(c-d)$ amostra Z3Y i; (e - f) amostra ALZ3Y i

Figura 5.4.14 - Curvas de viabilidade celular obtidas no teste de citotoxicidade dos extratos das cerâmicas à base de alumina e zircônia infiltradas com fase vítrea de aluminoborossilicato de lantânio $\mathrm{V}-\mathrm{AL}(\mathrm{m}), \mathrm{V}-\mathrm{ALZ3Y}(\mathrm{m})$ e $\mathrm{V}-\mathrm{Z3Y}(\mathrm{m})$, e controles positivos e negativos. 89 


\section{INTRODUÇÃO}

Cerâmicas geralmente são definidas como materiais sólidos constituídos por compostos formados entre elementos metálicos e não metálicos, frequentemente óxidos, carbetos e nitretos, cujas ligações interatômicas são de natureza iônica e/ou covalente. Dentre esta classe de materiais situam-se as biocerâmicas que podem ser descritas como materiais naturais ou sintéticos passíveis de serem introduzidos harmonicamente em tecidos vivos, especialmente como parte de dispositivos médicos-odontológicos ${ }^{1}$.

O uso de biocerâmicas como material substituto dos dentes naturais, apresenta 4000 anos de história, sendo verificada já na civilização Maia, em crânios apresentando a substituição de dentes perdidos por substitutos esculpidos em madrepérola. A sua prática clínica em odontologia, no entanto, só iniciou-se no século XVIII com o uso de porcelanas em coroas dentais e, mais tarde, já no século XIX, na ortopedia com o uso do gesso de Paris como material de preenchimento ósseo ${ }^{1}$. Com os avanços ocorridos durante o século $X X$ na tecnologia de processamento, os materiais cerâmicos começaram a apresentar melhor desempenho mecânico, intensificando as aplicações desses materiais na medicina e odontologia. Um grande marco neste sentido foi alcançado em 1965 quando a primeira prótese de quadril, confeccionada em alumina, foi patenteada. Posteriormente, cerâmicas sintéticas à base de zircônia surgiram como material alternativo ${ }^{2}$.

Além da melhora das propriedades mecânicas, a aplicação de cerâmicas como biomaterial odontológico criou a necessidade de características estéticas compatíveis ao dente natural. A cor branca e os tons marfim concederam considerável vantagem aos óxidos cerâmicos quando comparados aos metais, sendo este, um dos motivos do uso de biocerâmicas na confecção de 
restaurações protéticas. Outras propriedades, tais como, biocompatibilidade, estabilidade química e capacidade de mimetização dos tecidos dentários, são fatores que impulsionaram o desenvolvimento e a introdução de inúmeros sistemas cerâmicos na odontologia ${ }^{3-5}$.

O conceito de prótese livre de metal surgiu na década de 60 com McLean \& Hughes 4 , ainda utilizando técnicas convencionais de confecção. Estes pesquisadores reportaram que a resistência mecânica das cerâmicas reforçadas com alumina tem dependência direta com a fração volumétrica de material cristalino incorporado na matriz vítrea, tendo como limitação falhas devido à formação de porosidade residual após o processo de sinterização ${ }^{5-8}$. Estudos subseqüentes mostraram que a melhora das propriedades mecânicas pode ser atingida com o controle da composição química e microestrutura, adequando-se os parâmetros de processamento ${ }^{6}$.

Introduzido em 1989, como o primeiro sistema totalmente cerâmico usado para próteses fixas anteriores de 3 elementos, os sistemas In-Ceram® (Vita Zahnfabrik, Bad Sackingen, Alemanha), surgiram como uma nova tecnologia em que se utiliza alumina, compósito alumina-zircônia ou espinélio $\left(\mathrm{MgAl}_{2} \mathrm{O}_{4}\right)$, como fase cristalina e a técnica de colagem de barbotinas (slip casting) para produção das infraestruturas dentais. Nessa técnica, verte-se sobre um molde de gesso a suspensão contendo o óxido cerâmico, conformando a infraestrutura no formato desejado. Em seguida, a peça a verde é sinterizada à $1120^{\circ} \mathrm{C}$ por 10 horas, produzindo assim uma estrutura porosa com densidade correspondente a $70 \%$ do valor teórico. Sequencialmente, a cerâmica é submetida a um segundo tratamento térmico, onde a estrutura porosa é infiltrada com vidro à base de aluminoborossilicato de lantânio, à $1100^{\circ} \mathrm{C}$ por 4 horas, melhorando a resistência mecânica e limitando a propagação de trincas. A presença de tensão residual compressiva, devido à diferença dos coeficientes de expansão térmica dos óxidos cerâmicos e do vidro, promove uma melhora adicional nas propriedades mecânicas do material ${ }^{6-7,9-14}$, o qual apresenta resistência à flexão situada entre 
236 - $600 \mathrm{MPa}$ e tenacidade à fratura entre 3,1 - 4,6 MPa.m ${ }^{1 / 2}$, No caso do InCeram ${ }^{\circledR}$ Alumina as características estéticas dos elementos dentais são alcançadas pelo recobrimento deste material com uma cerâmica feldspática aluminizada $^{15-16}$.

A mais recente variedade de cerâmicas utilizadas em próteses parciais fixas e coroas cerâmicas é a zircônia tetragonal policristalina (TZP - tetragonal zirconia polycrystal), muito utilizada na área biomédica. Este material apresenta valores elevados de tenacidade à fratura, bom acabamento de superfície, boa resistência ao desgaste e biocompatibilidade ${ }^{17}$. A ítria é considerada um dos dopantes mais efetivos para estabilização da estrutura tetragonal da zircônia, devido à extensa faixa de solubilidade desta fase. Por outro lado, deve-se salientar a degradação a que as cerâmicas de zircônia-ítria são propensas, quando em presença de umidade a temperaturas inferiores a $300^{\circ} \mathrm{C}$, situação não rara em procedimentos de esterilização, resultando na redução da resistência mecânica, devido à transformação espontânea dos cristais tetragonais metaestáveis para a estrutura monoclínica ${ }^{18-21}$. Considerando-se esta limitação, compósitos à base de alumina e zircônia têm sido desenvolvidos ${ }^{22}$.

Os compósitos contendo zircônia dispersa em matriz de alumina, conhecidos como ZTA (zirconia toughened alumina), apresentam um ganho de tenacidade, mantendo as propriedades vantajosas da alumina, tais como excelente resistência ao desgaste e estabilidade química ${ }^{22-23}$. As cerâmicas policristalinas de alumina e zircônia são obtidas por sinterização em temperaturas mais elevadas (superiores a $1400^{\circ} \mathrm{C}$ ), a partir de cerâmicas conformadas por colagem de barbotinas ou prensagem ${ }^{46-47}$. Infraestruturas de alta precisão dimensional são obtidas com a técnica CAD-CAM (Computer-Aided-DesignComputer-Aided-Machining) que fornece subsídios para a usinagem de blocos cerâmicos ${ }^{24}$. Contudo, a ausência de fase vítrea provoca limitações quanto à adesão ao sistema resinoso, requerendo tratamentos de superfície mais eficientes que envolvem ataques químicos e jateamento com partículas de alumina e/ou 
sílica que podem comprometer a integridade da cerâmica, devido à natureza frágil, em relação aos metais ${ }^{25}$. Neste sentido, as cerâmicas à base de alumina e zircônia com infiltração de fase vítrea de aluminoborossilicato de lantânio continuam sendo um alternativa promissora para aplicação na confecção de infraestruturas dentais. 


\section{OBJETIVOS}

Esta dissertação tem como objetivo o estudo de síntese e processamento de compósitos à base de alumina e zircônia estabilizada com ítria, infiltradas com fase vítrea de reforço de aluminoborossilicato de lantânio para aplicação como infraestrutura em restaurações dentais. A presença de alumina como fase majoritária na matriz visa a minimização da transformação de fases tetragonal $\rightarrow$ monoclínica, que pode ocorrer na zircônia estabilizada com ítria na fase tetragonal, em processos de esterilização ou em aplicação "in vivo" do material. A rota empregada para síntese dos pós contendo alumina e/ou zircônia foi a coprecipitação de hidróxidos, a qual inclui também etapas de secagem, calcinação e moagem. As condições de sinterização das cerâmicas conformadas por prensagem uniaxial foram selecionadas visando a preparação de um corpo poroso com densidade correspondente a $70 \%$ do valor teórico, para permitir a incorporação da fase vítrea de reforço preparada neste trabalho por fusão de óxidos. A análise microestrutural das amostras obtidas, assim como os resultados de dureza e tenacidade à fratura, possibilitaram a verificação da eficácia das condições de processo adotadas para obtenção das infraestruturas dentais. 


\section{REVISÃO DA LITERATURA}

\subsection{Dentição e estruturas de suporte}

A dentição humana é composta por 32 dentes igualmente divididos entre maxila e mandíbula, agrupados segundo a morfologia da coroa dental. Na região anterior dos arcos encontram-se os incisivos, com forma característica de pá, atuam no corte do alimento durante a mastigação. Posteriormente aos incisivos estão os caninos, situados nos cantos das arcadas dentárias, são geralmente os dentes de maior comprimento e atuam semelhantemente aos incisivos. Ainda mais posteriores estão os pré-molares, com significativo aumento na área de mastigação devido à presença de duas cúspides na coroa dental, atuam na quebra inicial do alimento. A última classe dos dentes são os molares, dentes com 4 ou 5 cúspides na coroa proporcionando ampla superfície para trituração dos alimentos ${ }^{26}$. É apresentado na FIG. 3.1.1 um desenho esquemático da posição dos dentes naturais.

Os dentes são constituídos por duas partes básicas: a coroa, porção exposta e situada sobre o tecido gengival, e a raiz, submersa e circundada por osso alveolar. A raiz está presa ao osso alveolar pelo ligamento periodontal, composto por numerosas fibras de tecido conjuntivo que se espalham, obliquamente, da superfície da raiz para o osso. O ligamento periodontal não somente prende o dente ao osso alveolar - alvéolo dental - como também ajuda a dissipar as forças provenientes do contato funcional dos dentes, principalmente durante a mastigação ${ }^{26}$. 


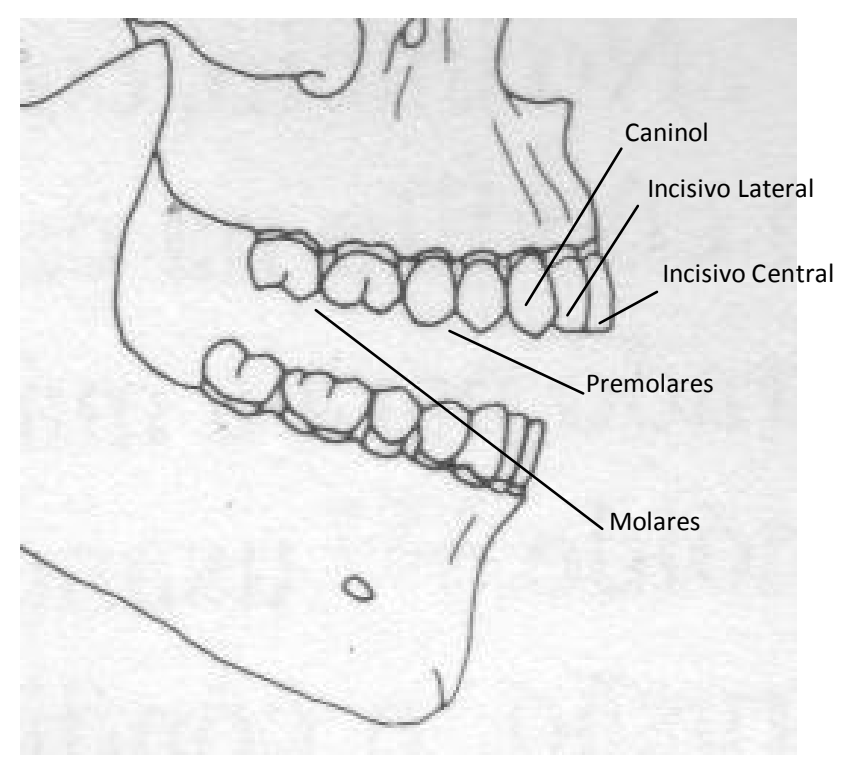

FIGURA 3.1.1 - Desenho esquemático dos dentes naturais vistos lateralmente ${ }^{30}$.

Conforme descrito na TAB. 3.1.1, as maiores forças naturais exercidas sobre os dentes ocorrem durante a mastigação. As forças máximas de mastigação e de mordida diferem entre si, variando muito entre indivíduos uma vez que depende da dentição presente. Muitos estudos foram realizados no intuito de quantificar a força normal máxima de mordida, variando em metodologia e resultados. Recentemente, estudos indicam forças verticais de mordida entre 200 e $2500 \mathrm{~N}$, sendo semelhantes em amplitude entre os lados de mordida e oposto 27

TABELA 3.1.1 - Características das forças normais exercidas sobre os dentes ${ }^{27}$.

\section{Forças de Mordida}

Perpendiculares ao plano oclusal, curta duração, período total curto $(9 \mathrm{~min} / \mathrm{dia})$

Força em cada dente: 20 a 30 psi, força máxima de mordida: 50 a 500 psi

\section{Forças Peribucais}

Mais constantes, fracas, horizontais

Máximas durante a deglutição (3 a 5 psi), tempo de deglutição (20 min/dia) 


\subsection{Estrutura do dente natural}

Na FIG. 3.2.1 é apresentada uma ilustração esquemática de um dente natural, indicando as camadas que o compõe. Por proteção, a camada de esmalte pode chegar a ter $2 \mathrm{~mm}$ de espessura em determinadas regiões ${ }^{26-28}$.

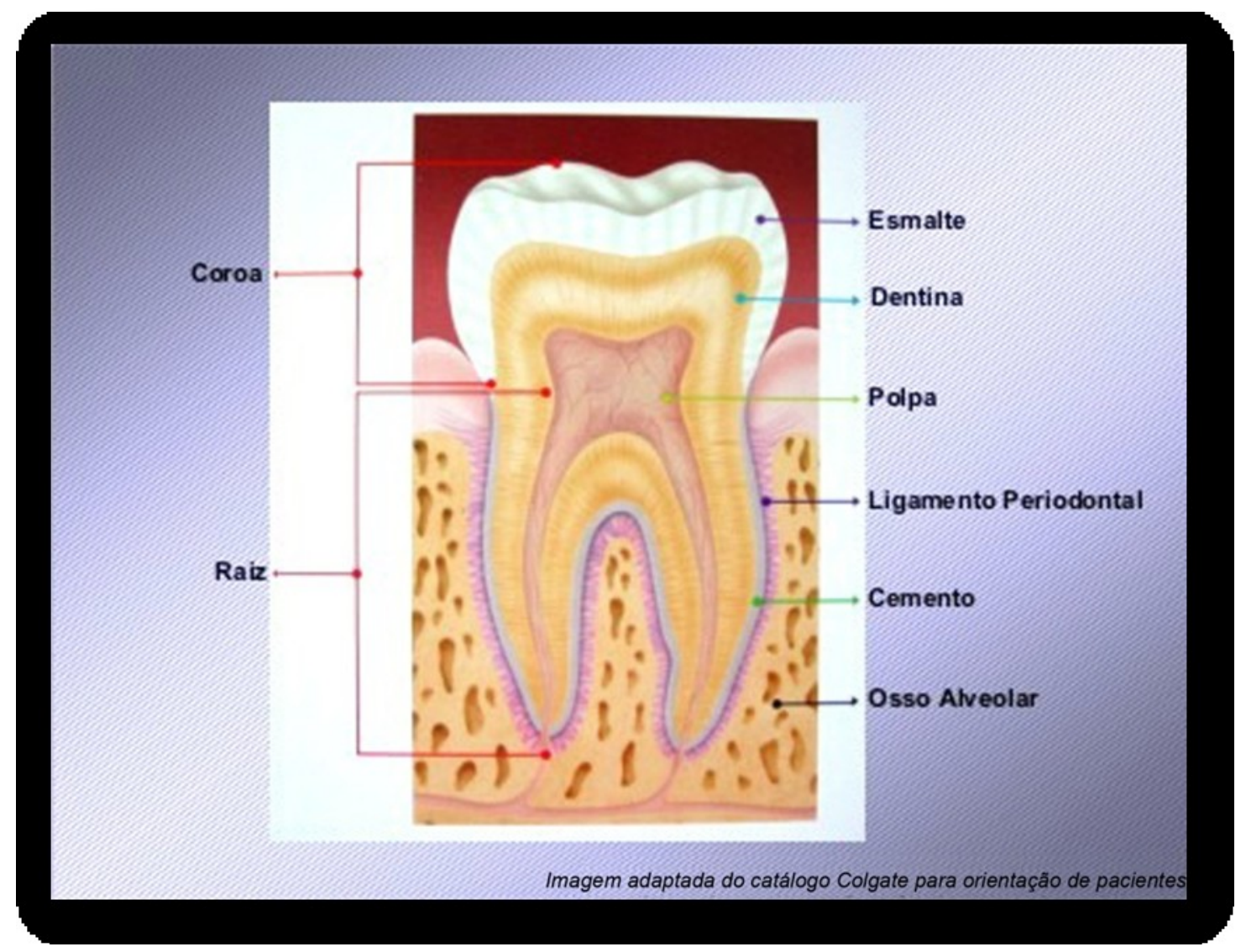

FIGURA 3.2.1 - Ilustração de um dente molar em sua secção transversal.

O dente é constituído basicamente por hidroxiapatita, um fosfato de cálcio cristalino de fórmula química $\mathrm{Ca}_{5}\left(\mathrm{PO}_{4}\right)_{3}(\mathrm{OH})$ que representa $99 \%$ do cálcio corporal e $80 \%$ do fósforo total depositados. Esse mineral é um hidrofosfato de cálcio de baixa solubilidade, que se dissolve em ácido, já que tanto o $\mathrm{PO}_{4}{ }^{3-}$ quanto o $\mathrm{OH}^{-}$reagem com $\mathrm{H}^{+}$, segundo a seguinte reação: 


$$
C a_{5}\left(\mathrm{PO}_{4}\right)_{3}(\mathrm{OH})+7 \mathrm{H}^{+} \rightarrow 5 \mathrm{Ca}_{2}+3 \mathrm{H}_{2} \mathrm{PO}_{4}+\mathrm{H}_{2}
$$

As bactérias que causam a deterioração se aderem aos dentes e produzem ácido lático através do metabolismo de açúcar, diminuindo o $\mathrm{pH}$ na superfície. Em $\mathrm{pH}$ inferior a 5,5, a hidroxiapatita começa a dissolver e ocorre a deterioração dos dentes. O íon fluoreto inibe a deterioração dos dentes, formando fluorapatita, $\mathrm{Ca}_{5}\left(\mathrm{PO}_{4}\right) 3 \mathrm{~F}$, que é menos solúvel e mais resistente a ácidos do que a hidroxiapatita ${ }^{29}$.

Divididos em coroa e raiz, os dentes naturais apresentam alta dureza, coloração esbranquiçada e diferentes camadas constituintes. A coroa dental é constituída por esmalte, dentina e polpa dental ${ }^{26-29 .}$

\subsubsection{Esmalte}

Camada mais superficial da coroa e o mais resistente e mineralizado tecido do corpo. Em condições normais é o componente da coroa visto sobre o tecido gengival, é suportado pela dentina e composto por $96 \%$ de matéria inorgânica, $1 \%$ de matéria orgânica e $3 \%$ de água. Sua coloração usualmente varia entre amarelo claro e branco acizentado no corpo do dente e levemente azulado nas bordas onde não há dentina subjacente. O esmalte é um tecido translúcido e a cor da dentina e/ou qualquer material abaixo do esmalte dentário afeta significativamente sua aparência. Sua espessura varia ao longo da superfície dentária sendo, normalmente, mais espessa nas cúspides e mais fina na junção entre coroa e raiz. O mineral principal da estrutura do esmalte é a hidroxiapatita. Ao contrário da dentina e do tecido ósseo, o esmalte não contém colágeno em sua composição. As proteínas que integram sua estrutura são: enamelina e 
amelogenina. Seu elevado conteúdo mineral é responsável por sua alta susceptibilidade à desmineralização, por ácidos salivares e bacterianos, e sua acentuada fragilidade, sendo, desta forma, um tecido extremamente quebradiço, incapaz de resistir aos estresses mastigatórios quando não suportado pela dentina. Sua estrutura é composta por cristais de hidroxiapatita orientados espacialmente de diferentes formas, denominados primas de esmalte e são separados entre si por substância interprismática de composição semelhante, orientada em sentido diferente à dos primas. Clinicamente, apresenta-se como um tecido duro, sem vitalidade, sem sensibilidade e não renovável quando destruído devido à cárie ou desgaste. Apresenta, de forma restrita, permeabilidade para trocas iônicas entre sua estrutura e o ambiente bucal e, quando submetido a aplicações tópicas de flúor em sua superfície, torna-se mais resistente ao ataque ácido devido à substituição da hidroxila da hidroxiapatita, pelo íon flúor ${ }^{27-29}$.

\subsubsection{Dentina}

É um tecido conjuntivo altamente especializado, mineralizado e sem vascularização, que compõe a maior porção do dente dando corpo e suportando o cemento radicular e o esmalte dental, externamente, e delimitando a cavidade pulpar, internamente. Apresenta-se como um tecido duro, elástico, de coloração branca-amarelada, composto por cerca de $70 \%$ de cristais de hidroxiapatita, $20 \%$ de matéria orgânica, basicamente composta por colágeno e $10 \%$ de água. É considerado um tecido vivo, apresentando substância intercelular e permeado por túbulos dentinários onde prolongamentos de células especializadas estão presentes. Estas células são denominadas odontoblastos e conferem à dentina além de sensibilidade, a capacidade de reparação. Podem ocorrer variações na estrutura de mineralização estabelecidas durante sua formação, caracterizando as linhas incrementais. O curso das linhas corresponde aos períodos rítmicos de aposição de dentina. Na coroa varia de 4 a $8 \mu \mathrm{m}$ a aposição diária de dentina. $\mathrm{Na}$ 
raiz, a aposição dentinária é mais lenta. Ocasionalmente algumas destas linhas estão acentuadas devido a distúrbios no processo de mineralização e são conhecidas como linhas de contorno de Owen ${ }^{27-29}$.

\subsubsection{Polpa dental}

Porção realmente vital do dente; é constituída por tecido conjuntivo frouxo altamente inervado e vascularizado e apresenta-se como um tecido mole altamente suscetível a macerações provenientes do tratamento dentário. Tem como funções básicas, promover a formação da dentina que a circunda, nutrir a dentina, proteger o dente de eventos nocivos através de sua sensibilidade e induzir o processo de reparo da dentina. Sendo um tecido altamente vascularizado e, desta forma, responsável pela vitalidade do dente, nenhum biomaterial atua substituindo-o, mas somente protegendo-o de estímulos que comprometam sua integridade ${ }^{27-29}$.

\subsection{Prótese parcial fixa}

A confecção e fixação de próteses parciais fixas são procedimentos odontológicos, que reabilitam um dente ou toda a oclusão, onde, utilizando-se de um material sintético em substituição ao tecido dentário perdido, o dente volta a exercer suas funções totalmente ou, em certos casos, parcialmente, pois acaba perdendo a sensibilidade com a remoção da polpa dental. Na restauração de um único dente - prótese fixa unitária - é possível restabelecer integralmente função e melhorar em muito a estética da restauração. Em próteses que envolvem mais de um dente - prótese parcial fixa - é possível substituir dentes fragilizados e 
preencher as perdas dentais existentes, contribuindo assim para o conforto durante a mastigação, convívio social e manutenção da saúde bucal ${ }^{30}$.

\subsubsection{Terminologia}

\subsubsection{Coroa}

Restauração dentária que recobre ou reveste a superfície exterior da coroa dental. Deve reproduzir a morfologia e os contornos das porções coronárias danificadas do dente, enquanto este estiver em função, e proteger a estrutura remanescente de futuras lesões. Quando recobre toda a coroa clínica do dente é chamada de coroa total (FIG. 3.3.1.1), e pode ser obtida integralmente em liga de ouro ou outro metal que não sofra corrosão, de cerâmica fundida sobre metal (metalocerâmica), de material totalmente cerâmico (metal-free ou ceramocerâmica), de resina sobre metal ou toda em resina. Quando recobre parcialmente a coroa clínica do dente é chamada de coroa parcial (FIG. 3.3.1.2) 30 .

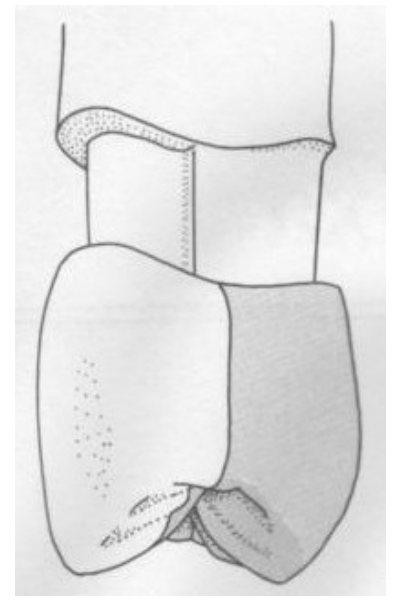

FIGURA 3.3.1.1 - Coroa total metalocerâmica $^{30}$.

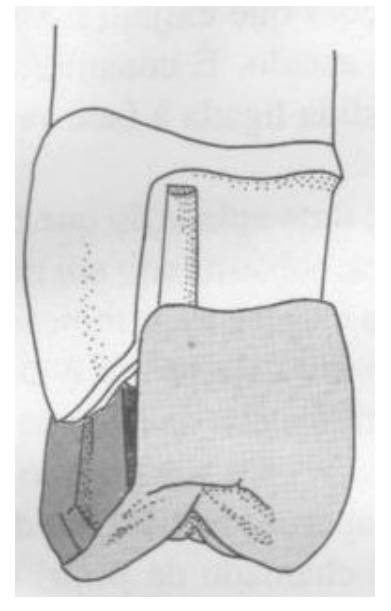

FIGURA 3.3.1.2 - Coroa parcial metálica $^{30}$. 


\subsubsection{Restaurações intracoronárias fundidas}

Restaurações que se adaptam à anatomia dos contornos internos da coroa dental. Em dentes unitários, podem ser utilizadas restaurações indiretas em liga áurica ou cerâmica pura, com (onlay) ou sem (inlay) o envolvimento de cúspides, em situações onde a perda de estrutura dentária tenha extensão mínima ou moderada. Nas FIG. 3.3.1.3 e 3.3.1.4 apresentam-se, respectivamente, desenhos esquemáticos de inlays em metal e cerâmica e de uma onlay metálica ${ }^{30}$.

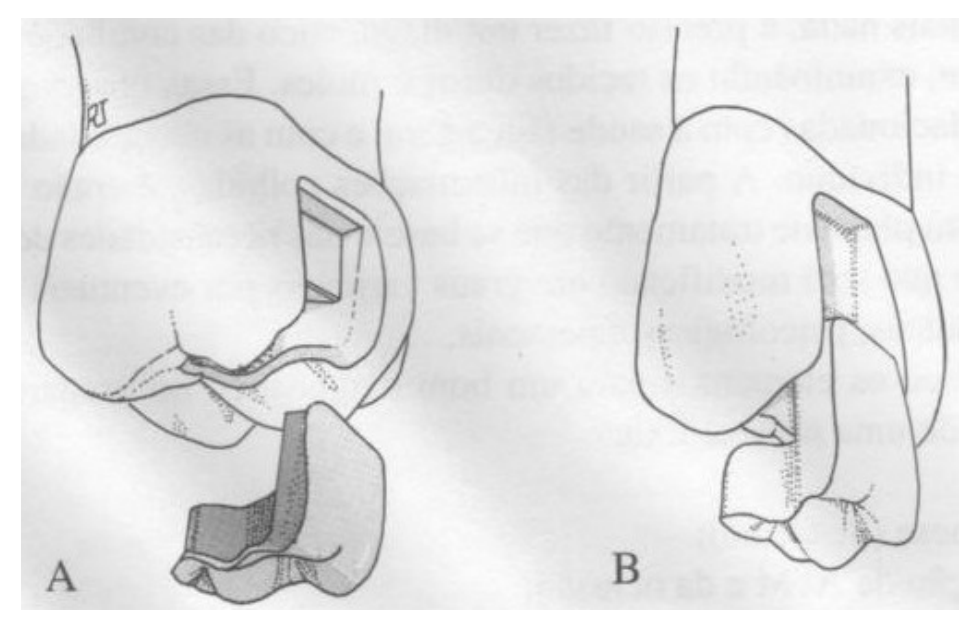

FIGURA 3.3.1.3 - (A) Inlay metália e (B) inlay cerâmica ${ }^{30}$.

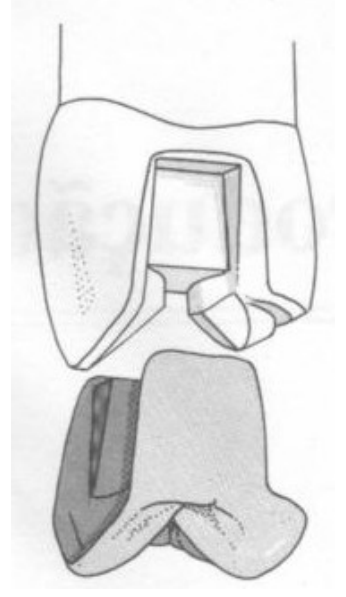

FIGURA 3.3.1.4 - Onlay metálica ${ }^{30}$. 


\subsubsection{Faceta laminada de porcelana}

Restauração realizada em dentes em que 0 aspecto estético é fundamental, sendo realizada normalmente em dentes anteriores. É constituída de uma fina camada de porcelana ou cerâmica fundida unida à superfície dentária, via condicionamento ácido, por meio de resina. Na FIG. 3.3.1.5 apresenta-se uma ilustração de uma faceta dental laminada ${ }^{30}$.

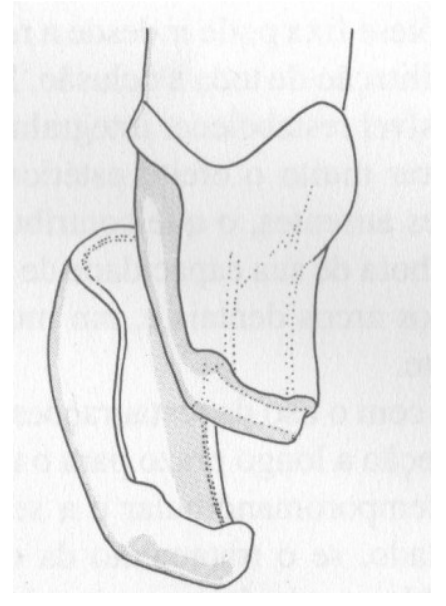

FIGURA 3.3.1.5 - Faceta laminada em cerâmica ${ }^{30}$.

\subsubsection{Prótese parcial fixa}

Também conhecida como ponte, é uma restauração que fica permanentemente ligada aos remanescentes dentários, substituindo os dentes ausentes. Quando o dente serve de inserção é chamado dente pilar, quando suspenso entre os pilares, reabilitando um espaço edêntulo, é chamado pôntico. O pôntico é ligado às próteses que são cimentadas sobre os pilares já preparados, denominadas retentores. Entre pôntico e retentor existem conectores que podem ser rígidos como os conectores fundidos, ou não-rígidos como os 
encaixes de precisão. Na FIG. 3.3.1.6 apresenta-se uma figura indicando os componentes de uma prótese parcial fixa de 3 elementos ${ }^{30}$.

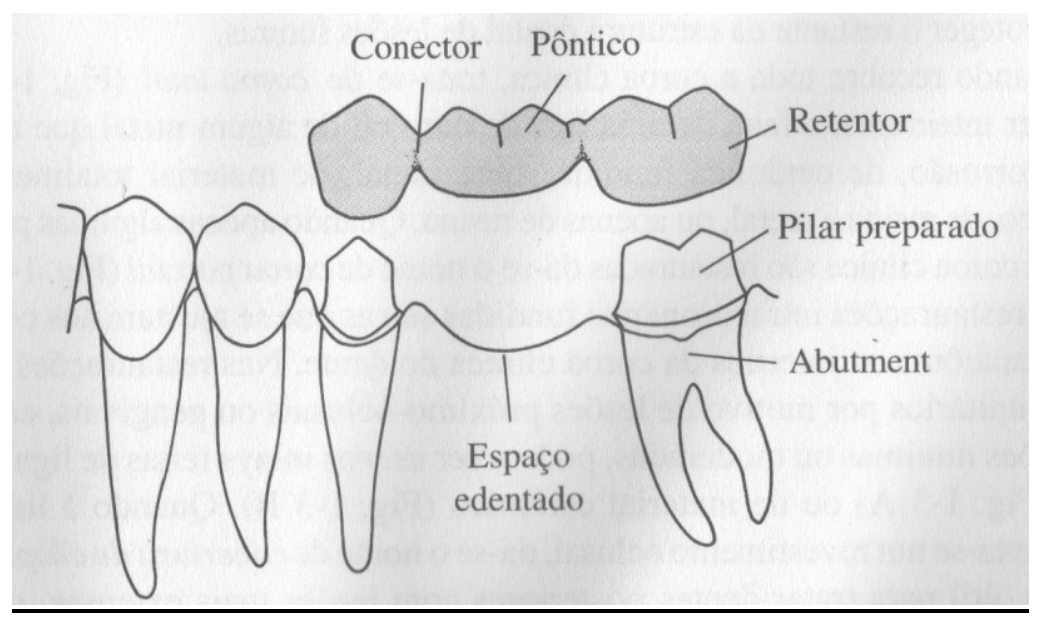

FIGURA 3.3.1.6 - Componentes de uma prótese parcial fixa ${ }^{30}$.

\subsection{Histórico dos materiais aplicados em Odontologia}

A aplicação de cerâmicas em odontologia restauradora é uma prática recente, mas o anseio por um material altamente estético e durável é antigo. A maioria das culturas antigas reconhece os dentes como parte integrante da estrutura facial e um sinônimo para saúde, juventude, beleza e dignidade. Dentes eram costumeiramente indicadores de poder, entretanto, certas culturas, não raramente, mutilavam dentições inteiras, inspiradas pela vaidade, moda, crenças místicas ou religiosas. Por isso, é quase universal que a perda inesperada da estrutura dental e, em particular, dos dentes anteriores criem problemas funcionais, físicos, psicológicos e, muitas vezes, sociais ${ }^{31}$. 
Presente na Etrúria, desde 700 a.C, e durante todo primeiro século antes de Cristo, como uma prática empírica, a tecnologia dental na confecção de substitutos para as perdas dentais, só iniciou seu desenvolvimento no século XVIII. Os materiais mais promissores e principais candidatos para a confecção de dentes artificiais durante o século XVIII foram: dentes humanos, dentes de animais esculpidos ao tamanho e forma de dentes humanos, marfim e, finalmente, dentes de porcelana ou minerais. Além de escassos, dentes humanos eram extremamente caros, logo, a seleção de materiais para dentes artificiais foi baseada na sua oferta, versatilidade mecânica e estabilidade biológica. Os dentes animais rapidamente causaram problemas devido a agentes corrosivos na saliva. Por sua vez, o marfim de elefante e o osso humano apresentavam grande quantidade de poros que retinham muitos detritos alimentares. O marfim de hipopótamo parece ter sido a melhor solução estética dentre os materiais utilizados na época ${ }^{31}$.

Os dentes minerais e as dentaduras de porcelana aceleraram o fim da prática da transplantação de dentes humanos, recentemente extraídos, suplantando o uso de produtos minerais e animais na odontologia restauradora. $A$ porcelana feldspática foi adaptada da formulação européia da cerâmica branca, quase coincidentemente com o seu desenvolvimento. Depois de décadas de esforço, por volta de 1720 , os europeus dominaram a manufatura da porcelana translúcida, comparável à porcelana chinesa ${ }^{31}$.

O uso do feldspato e as altas temperaturas de queima foram desenvolvimentos críticos para a melhora na qualidade da porcelana européia, dita, perfeita. As primeiras dentaduras de porcelana foram confeccionadas em 1774, substituindo o marfim anteriormente utilizado nas próteses. Em 1808 foram introduzidos, em Paris, os dentes de porcelana individuais que continham alfinetes de platina embutidos em seu interior, cuja versatilidade estética e mecânica forneceu um avanço gigantesco à prótese odontológica. Em 1723 foi reconhecido o potencial da porcelana esmaltada na mimetização da cor e forma 
dos dentes, mas as melhorias na translucidez e cor das porcelanas foram conquistadas graças às formulações de Elias Wildman, em 1838, e o desenvolvimento de fornos a vácuo, em 1949. Restaurações estéticas indiretas sem recobrimento de cúspides (Inlays), confeccionadas em vidro, foram introduzidas por Herbst em 1882, com fritas de vidro depositadas em moldes de gesso e amianto ${ }^{31}$.

Em 1885, Logan resolveu o problema de fixação encontrado entre coroas de porcelana e pinos de retenção, que eram comumente fabricados de madeira, com a fundição da porcelana a um pino de retenção de platina (coroa Richmond). Essas coroas com pinos de platina representaram o primeiro uso inovador de um sistema metalo-cerâmico, desde os dentes de dentadura fabricados com alfinetes de platina. Combinando folha metálica de platina polida com uma fundição em alta temperatura, realizada em um forno a gás, Land introduziu as primeiras inlays e coroas de porcelana feldspática fundida em 1886. Apesar das vantagens estéticas, a popularidade das coroas totalmente cerâmicas ocorreu com a introdução da alumina como uma fase de reforço ${ }^{31}$.

Um desenvolvimento notável ocorreu nos últimos 55 anos, com a adição de leucita $\left(\mathrm{KAISi}_{2} \mathrm{O}_{6}\right)$, às formulações de porcelana. Esta adição promove o aumento do coeficiente de expansão térmica das porcelanas, permitindo sua fusão a certas ligas áuricas e a confecção de coroas totais e próteses parciais fixas ${ }^{31}$.

As restaurações metalo-cerâmicas não possibilitam, no entanto, a transmissão de luz, diminuindo a capacidade de reprodução das características vitais dos dentes naturais. Neste contexto, vários sistemas puramente cerâmicos, em que uma infra-estrutura cerâmica de alta resistência mecânica é recoberta por porcelanas, vêm sendo desenvolvidos para que a estética seja alcançada, sem comprometimento das propriedades mecânicas ${ }^{14,31}$. O primeiro material cerâmico para esta finalidade foi sintetizado no decorrer dos anos 60 por McLean \& Hughes 
${ }^{8}$, sendo constituído por uma infraestrutura à base de feldspato reforçada com 40 a $50 \%$ em massa de alumina. A partir deste momento ocorreu uma evolução dos materiais cerâmicos para aplicações odontológicas, culminando, no final da década de 80, com o desenvolvimento de sistemas contendo uma fase cristalina majoritária (alumina e/ou zircônia) e uma fase vítrea (aluminoborossilicato de lantânio ) 14, 32. As infra-estruturas cerâmicas infiltradas por vidro, conhecidas comercialmente como sistemas In-Ceram ${ }^{\circledR}$ (Vita-Zahnfabrik, Bad Sachingen, Alemanha), foram desenvolvidas em três versões: Alumina, Zirconia e Spinell $\left(\mathrm{MgAl}_{2} \mathrm{O}_{4}\right)$, sendo as duas primeiras as mais difundidas. Esses sistemas são constituídos por $75 \%$ em massa de fase cristalina e $25 \%$ de fase vítrea. No caso do sistema In-Ceram® Zircônia a matriz cristalina é constituída por $67 \%$ em massa de alumina e $33 \%$ de zircônia estabilizada com $12 \mathrm{~mol} \%$ de céria (Ce-TZP). Como vantagens, esses materiais apresentam boa adesão aos agentes cimentantes resinosos, que promovem a união, à estrutura dental, da cerâmica de infraestrutura, e variação dimensional desprezível durante as estapas de processamento, facilitando a confecção e adaptação da infraestrutura ao dente a ser reabilitado ${ }^{36-40}$.

O aprimoramento dos sistemas reforçados por alumina fez surgir a possibilidade de se desenvolver sistemas compostos por alumina de alta pureza $(99,9 \%)$. Assim, no início dos anos 90, surgiu a infraestrutura Procera AllCeram ${ }^{\circledR}$ (Nobel Biocare, Gotemburgo, Suécia), garantindo densificação elevada e alta resistência à flexão $(700 \mathrm{MPa})^{14}$. Assim como a alumina, a zircônia estabilizada com $3 \mathrm{~mol} \%$ de ítria ou $12 \mathrm{~mol} \%$ de céria, também denominada zircônia tetragonal policristalina (TZP - tetragonal zirconia polycrystals) apresenta excelente biocompatibilidade ${ }^{42-44}$ e boa resistência ao desgaste. As cerâmicas à base de zircônia apresentam também como vantagem a elevada resistência à fratura devido à transformação da fase tetragonal para monoclínica que, acompanhada por aumento de volume da ordem de 4\%, provoca a formação de microtrincas ${ }^{43}$, responsável pelo reforço mecânico, mecanismo este descoberto por Garvie ${ }^{45}$ em 1975. 
As cerâmicas policristalinas de alumina e zircônia conformadas por colagem de barbotinas ou prensagem, são obtidas por sinterização em temperaturas superiores a $1400^{\circ} \mathrm{C}$. O ajuste dimensional é obtido por usinagem dos blocos cerâmicos com o auxílio da técnica CAD-CAM (Computer-AidedDesign-Computer-Aided-Machining) ${ }^{46-47}$.

\subsection{Cerâmicas odontológicas}

São materiais compostos por elementos metálicos e não-metálicos que apresentam, quando comparados aos metais e compósitos utilizados em restaurações odontológicas, vantagens tais como a alta capacidade de mimetizar os dentes naturais devido à capacidade de reproduzir as características ópticas observadas nos dentes naturais, boa biocompatibilidade, estabilidade química e física, mantendo a cor e a textura por períodos prolongados, e resistência à abrasão ${ }^{48-49}$. Entretanto, as cerâmicas odontológicas, apresentam características que fazem com que seu uso seja restrito a casos clínicos específicos. Dentre estas características destacam-se a baixa tenacidade à fratura em relação aos metais (10 vezes menor em alguns casos) e dureza elevada, que pode provocar desgaste do esmalte do dente antagonista quando sua superfície encontra-se rugosa ou quando o paciente apresenta alguma parafunção, como por exemplo o bruxismo ${ }^{48-50}$.

O desenvolvimento de restaurações metalocerâmicas e de cerâmicas dentais de alta resistência dominou a última parte do século XX. A união direta de coroas metalocerâmicas, coroas cerâmicas e inlays em dentes com preparos conservadores com mínimo desgaste de estrutura dental, utilizando-se de cimentos resinosos de baixa viscosidade, tornaram-se uma prática comum, propiciando assim maior eficácia à união entre cerâmica e tecido dentário ${ }^{46-47}$. 
As cerâmicas odontológicas podem ser classificadas de acordo com o tipo de material e prótese a ser confeccionada, técnicas de processamento adotadas, ou pelo material de infraestrutura utilizado, no caso da classificação por tipo de material, destacam-se as seguintes categorias: porcelana convencional contendo leucita, porcelana enriquecida com leucita, porcelana de ultrabaixo ponto de fusão que pode conter leucita, cerâmicas vítreas, cerâmicas especiais para infraestruturas de próteses fixas (aluminizada, alumina infiltrada por vidro, magnésio, espinélio, zircônia tetragonal estabilizada, zircônia-alumina infiltrada por vidro), e cerâmicas CAD-CAM ${ }^{48}$.

Kelly ${ }^{51}$ afirma que há somente três classes principais de cerâmicas odontológicas: cerâmicas predominantemente vítreas, cerâmicas vítreas reforçadas com partículas e cerâmicas policristalinas; e que estas podem ser consideradas como compósitos. Afirma também que, geralmente, cerâmicas que propiciam melhor aspecto estético são predominantemente vítreas e cerâmicas de elevada resistência mecânica são predominantemente cristalinas.

Raigrodski ${ }^{14}$ publicou em 2004 um levantamento da evolução e desenvolvimento de sistemas cerâmicos para próteses fixas livres de metal, discutindo os diferentes materiais e suas propriedades, dados disponíveis de estudos in vitro e in vivo, tecnologias de confecção e a metodologia de seleção dos pacientes. Foi ressaltado que novos materiais cerâmicos de alta resistência mecânica vêm sendo desenvolvidos para o uso em próteses fixas livres de metal, com aplicação restrita à região de dentes anteriores e premolares, devido à limitação das propriedades inerentes a estes materiais. Outros fatores que devem ser levados em conta são a necessidade de conectores com maiores dimensões e a maior habilidade técnica necessária do clínico durante os procedimentos adesivos. Na tentativa de ampliar o tratamento reabilitador livre de metal até os dentes posteriores e propiciar melhor desempenho mecânico quando utilizado em dentes anteriores, surgiram alguns sistemas à base de zircônia tetragonal estabilizada com ítria, que em alguns casos, são manufaturados com o uso de 
técnicas simples com bons resultados estéticos. Estudos clínicos sobre o sucesso a longo prazo deste tipo de restauração são limitados, o que é indispensável para se estabelecer melhores especificações de uso. Na TAB. 3.5.1 são apresentadas algumas propriedades mecânicas dos sistemas totalmente cerâmicos disponíveis no mercado ${ }^{14}$. Dados relativos a técnica de processamento e aplicações clínicas são apresentadas na TAB. 3.5.2 ${ }^{52}$.

TABELA 3.5.1 - Características de sistemas totalmente cerâmicos para próteses fixas $^{14}$.

\begin{tabular}{cccc}
\hline Marca Comercial & $\begin{array}{c}\text { Material } \\
\text { Cerâmico }\end{array}$ & $\begin{array}{c}\text { Resistência à } \\
\text { Flexão (MPa) }\end{array}$ & $\begin{array}{c}\text { Tenacidade à } \\
\text { Fratura KIC } \\
\text { (MPa.m }{ }^{1 / 2} \text { ) }\end{array}$ \\
\hline $\begin{array}{c}\text { Empress II } \\
\begin{array}{c}\text { In-Ceram } \\
\text { Alumina }\end{array}\end{array}$ & $\begin{array}{c}\text { Alumina infiltrada } \\
\text { por vidro }\end{array}$ & $236-600$ & $2,8-3,5$ \\
\hline $\begin{array}{c}\text { In-Ceram } \\
\text { Zirconia }\end{array}$ & $\begin{array}{c}\text { Alumina-Zircônia } \\
\text { infiltrada por vidro }\end{array}$ & $421-800$ & $3,1-4,61$ \\
\hline $\begin{array}{c}\text { Procera AllCeram } \\
\text { Alumina densa de } \\
\text { alta pureza }\end{array}$ & $487-699$ & $6,48-6$ \\
\hline Cercon & Y-TZP & $900-1200$ & $9-10$ \\
\hline $\begin{array}{c}\text { DCS-Precident } \\
\text { DC- Zirkon }\end{array}$ & Y-TZP & $900-1200$ & $9-10$ \\
\hline Lava & Y-TZP & $900-1200$ & $9-10$ \\
\hline
\end{tabular}


TABELA 3.5.2 - Materiais cerâmicos, denominações comerciais e técnicas de manufatura de alguns sistemas totalmente cerâmicos ${ }^{52}$.

\begin{tabular}{|c|c|c|}
\hline $\begin{array}{l}\text { Material } \\
\text { Cerâmico }\end{array}$ & Marca Comercial & $\begin{array}{l}\text { Técnica de } \\
\text { Manufatura }\end{array}$ \\
\hline \multirow{2}{*}{$\begin{array}{c}\text { Dissilicato de } \\
\text { Lítio }\end{array}$} & IPS Empress 2 & $\begin{array}{c}\text { Prensagem a } \\
\text { quente }\end{array}$ \\
\hline & IPS e.max Press & $\begin{array}{c}\text { Prensagem a } \\
\text { quente }\end{array}$ \\
\hline \multirow{3}{*}{ Leucita } & IPS Empress & $\begin{array}{c}\text { Prensagem a } \\
\text { quente }\end{array}$ \\
\hline & $\begin{array}{c}\text { Optmal Pressable } \\
\text { Ceramic }\end{array}$ & $\begin{array}{c}\text { Prensagem a } \\
\text { quente }\end{array}$ \\
\hline & IPS ProCAD & Usinagem \\
\hline \multirow[t]{3}{*}{ Feldspato } & Vitablocs Mark II & Usinagem \\
\hline & VITA Triluce Bloc & Usinagem \\
\hline & $\begin{array}{c}\text { Vitablocs Esthetic } \\
\text { Line }\end{array}$ & Usinagem \\
\hline \multirow{5}{*}{ Alumina } & In-Ceram Alumina & $\begin{array}{c}\text { Colagem de } \\
\text { barbotinas; } \\
\text { usinagem }\end{array}$ \\
\hline & In-Ceram Spinell & usinagem \\
\hline & Synthoceram & usinagem \\
\hline & In-Ceram Zirconia & $\begin{array}{c}\text { Colagem de } \\
\text { barbotinas; } \\
\text { usinagem }\end{array}$ \\
\hline & Procera & Densificação \\
\hline \multirow{5}{*}{$\begin{array}{c}\text { Zircônia (Zircônia } \\
\text { Tetragonal } \\
\text { Policristalina } \\
\text { estabilizada com } \\
\text { Ítria) }\end{array}$} & Lava & $\begin{array}{c}\text { Usinagem a verde, } \\
\text { sinterização }\end{array}$ \\
\hline & Cercon & $\begin{array}{c}\text { Usinagem a verde, } \\
\text { sinterização }\end{array}$ \\
\hline & DC-Zircon & Usinagem \\
\hline & Denzir & Usinagem \\
\hline & Procera & $\begin{array}{l}\text { Densificação, } \\
\text { Usinagem }\end{array}$ \\
\hline
\end{tabular}

Em geral, um acréscimo no conteúdo cristalino de uma vitrocerâmica é acompanhado por um acréscimo em sua dureza e tenacidade. Entretanto, em materiais com conteúdo cristalino semelhante, outros fatores como: porosidade, tamanho de grão, forma e orientação são importantes na determinação de suas propriedades mecânicas ${ }^{53}$. 
Nos sistemas cerâmicos prensados, contendo dissilicato de lítio, a diferença média no crescimento de grão não afeta de forma mensurável sua dureza e tenacidade à fratura. Em sistemas de alumina reforçada com vidro, a mínima variação de tamanho do grão, forma ou orientação, têm um forte efeito sobre a dureza e tenacidade do material ${ }^{53}$.

\subsubsection{Cerâmicas odontológicas de cobertura}

O uso de matérias primas e condições de processamento implementadas por Vines em 1958, foi o primeiro aprimoramento com resultados estéticos consideráveis na translucidez de porcelanas odontológicas. A redução da granulometria dos pós de porcelana e a utilização do forno a vácuo deu início a uma nova era na estética dental ${ }^{31,34}$. A consagração da porcelana dental ocorreu mais facilmente, pois com o pó mais fino atinge-se maior densidade, facilitando a escultura e a deposição em camadas sobre a porcelana ainda a verde. A partir de 1960, foram desenvolvidas técnicas sofisticadas para fabricar coroas cerâmicas com coloração interna, aumentando a semelhança aos dentes naturais. Ambos, dentistas e técnicos de laboratório, tornaram-se mais conscientes da relevância estética existente na translucidez e na reflexão derivada da porcelana opaca ${ }^{31,54}$.

A leucita, silicato de alumínio e potássio $\left(\mathrm{KAISi}_{2} \mathrm{O}_{6}\right)$, foi adicionada à composição da porcelana utilizada em restaurações metalocerâmicas, inicialmente, para aumentar o seu coeficiente de expansão térmica, tornando-o compatível àquele das ligas utilizadas como infraestrutura, minimizando assim o estresse térmico residual. A análise da porcelana dental por Difração de Raios $X$ revelou que as concentrações de leucita são definitivamente alteradas após processamento. O resfriamento lento provoca aumento de 11 a $56 \%$ no teor de leucita da maioria de porcelanas. Quando mantida a $750^{\circ} \mathrm{C}$ durante 4 a 16 
minutos, o aumento foi de 6 a 21\%, em 6 marcas comerciais de porcelana. Esse aumento no teor de leucita é suficiente para causar alterações substanciais nos coeficientes térmicos de expansão das porcelanas em questão ${ }^{31,34,54 .}$

O resfriamento lento e a realização de vários ciclos de queima da porcelana em próteses parciais fixas podem provocar a ruptura precoce ou tardia na interface metal-cerâmica. Esta ruptura é atribuída a diferenças nos coeficientes de expansão térmica entre a liga metálica de infraestrutura e a porcelana de cobertura e de tensões térmicas decorrentes de diferentes taxas de transferência de calor. Como a leucita é considerada uma fase instável que altera a microestrutura da porcelana, repetidas queimas, resfriamento lento ou aumento do tempo de queima pode alterar o conteúdo de leucita, sendo assim, a porcelana de queima única, pode apresentar-se mais reforçada do que a porcelana submetida a múltiplas queimas. Cabe ressaltar, no entanto, que do ponto de vista estético, mudanças na composição das porcelanas utilizadas em restaurações metalocerâmicas não alteram sua cor ou translucidez ${ }^{31,34,54 .}$

As coroas reforçadas por folhas metálicas foram comercializadas sob várias formas por um longo tempo, porém nunca se destacaram pelo seu uso. Os motivos não são claros, pois, para coroas anteriores, a técnica da folha metálica era uma forma rentável e propiciava restaurações até certo ponto estéticas, sem a necessidade de se utilizar equipamentos sofisticados e de alto custo ${ }^{31,34}$.

O acoplamento de porcelanas a folhas metálicas surgiu para eliminar possíveis fraturas originadas na porcelana de cobertura. Neste sistema, a superfície de folha metálica de platina era revestida com até $2 \mu \mathrm{m}$ de latão. A oxidação do revestimento de latão fornecia a retenção por embricamento para a união metal-cerâmica. Posteriormente foram utilizados pós de ligas metálicas à base de ouro ou platina, impregnados sobre modelos refratários previamente à 
sinterização. Atualmente esse tipo de restauração cerâmica tem sua infraestrutura confeccionada através de eletrodeposição sob modelo apropriado ${ }^{34}$.

Com a evolução do materiais, novas técnicas foram desenvolvidas para manufaturar coroas metalo-cerâmicas que evitassem a visualização do metal. A fim de eliminar a cinta metálica da infraestrutura, porcelanas específicas foram desenvolvidas. Essencialmente, este tipo de porcelana tem uma temperatura de queima mais elevada e um maior fluxo térmico, o que, Ihe propicia, quando embutida, uma contração mínima. Contudo, a busca por se eliminar de uma vez por todas a infraestrutura metálica e substituí-la por uma infra-estrutura cerâmica de alta resistência ainda estava começando ${ }^{34}$.

A dispersão de materiais cerâmicos cristalinos de alta resistência mecânica e módulo de elasticidade, na matriz vítrea, pode reforçar uma porcelana. Apesar da matriz vítrea possuir uma expansão térmica semelhante à dos materiais cristalinos, a resistência e o módulo de elasticidade podem ser aumentados. McLean e Hughes ${ }^{55}$, estabeleceram que o reforço da porcelana de cobertura com a adição de 50\% em massa de alumina, possibilita compatibilidade no comportamento de expansão térmica. A resistência mecânica desses materiais é duas vezes maior que a dos materiais feldspáticos convencionais, sendo superior a $180 \mathrm{MPa}^{34}$.

É amplamente reconhecido que a porcelana opalescente não é uma descoberta recente, tendo seu aparecimento datado por volta de 1962, quando foram incorporados às porcelanas dentais comerciais, partículas (aproximadamente $5 \mu \mathrm{m}$ ), de alumina, alumínio, silicato de zircônio, zircônio ou óxidos metálicos. Esses opacificadores, são misturados ao pó de feldspato constituído por partículas de diâmetro inferior a $50 \mu \mathrm{m}$, e queimado a temperaturas superiores a $1500^{\circ} \mathrm{C}$. Durante o resfriamento, parte do opacificador é dissolvido e segregado em grãos de tamanho entre 0,8 e $0,4 \mu \mathrm{m}$, produzindo o 
efeito Rayleigh ${ }^{34}$, em que a porcelana apresenta-se azulada sob luz refletida e vermelho-amarelada sob luz transmitida. Contudo, no caso das porcelanas aluminizadas, os cristais de alumina devem permanecer intactos durante 0 processamento. O uso de partículas finas reduz a translucidez enquanto o uso de partículas grosseiras reduz a resistência mecânica, devendo existir compromisso entre resistência mecânica e estética ${ }^{34}$.

A porcelana de cobertura aluminizada foi projetada para ter uma expansão térmica ligeiramente superior à porcelana opalescente. A antiga porcelana opalescente tinha seu conteúdo cristalino de alumina dissolvido em altas temperaturas, o que dava a opalescência desejada. Durante certo período, utilizou-se um óxido fluorescente de urânio $\left(\mathrm{Na}_{2} \mathrm{U}_{2} \mathrm{O}_{1}\right)$, que produz uma cor intensa amarela-esverdeada. Na presença de óxido de cério, a fluorescência branca-azulada, muito semelhante a dos dentes humanos, é alcançada. A produção dessa porcelana conseguiu atingir um objetivo há muito perseguido, a capacidade de mimetizar em cor e translucência os dentes naturais. Sua primeira marca comercial foi a Vitadur (Vita), comercializada em 1966. O uso de fluorescentes radioativos foi desde então proibido e, até certo ponto, os padrões de estética que em muito se desenvolviam, comprometidos. As porcelanas aluminizadas para cobertura são muitos resistentes ao choque térmico e podem resistir a repetidas queimas sem perder suas características de translucidez, devido ao seu alto teor de alumina ${ }^{31}$.

Surgiu durante a década de 90, uma cerâmica vítrea comercializada sob o nome comercial Dicor (Dentsply). A cerâmica vítrea original continha cristais de $\mathrm{K}_{2} \mathrm{Mg}_{5} \mathrm{SiO}_{2} \mathrm{OF}_{4} \mathrm{e}$, devido a sua flexibilidade e morfologia semelhante à de uma placa, possibilitou resistência à propagação de fraturas. Devido à sua alta translucidez, a cerâmica vítrea Dicor, tem uma característica parecida a de um camaleão, quando comparada com os dentes circundantes mescla suas cores. Para tanto, a Dicor utiliza uma infraestrutura de porcelana aluminizada (menor que $1 \mathrm{~mm}$ de espessura), que tende a fraturar devido a problemas derivados de 
sua difusibilidade térmica ou baixo módulo de elasticidade. Embora seja altamente estética, a cerâmica Dicor, necessita de dureza suficiente para a espessura dos términos da restauração e também de união adesiva, que se realiza através de ataque ácido. A cerâmica Dicor, é melhor indicada para fabricação de restaurações estéticas indiretas sem recobrimento de cúspides (inlays), pois o problema de falhas em regiões onde a espessura de cerâmica é fina ainda não foi resolvido ${ }^{31}$.

\subsubsection{Cerâmicas odontológicas para infraestrutura}

\subsubsection{Cerâmicas à base de alumina}

A principal matéria-prima para a produção de alumina é a bauxita, formada basicamente por óxido de alumínio hidratado contendo óxido de ferro entre outras impurezas. O método mais econômico para o seu beneficiamento é baseado no processo Bayer de refinamento do alumínio, onde após aquecimento em soda cáustica e dissolução do alumínio, ocorre separação de $\mathrm{Fe}_{2} \mathrm{O}_{3}, \mathrm{TiO}_{2}, \mathrm{SiO}_{2} \mathrm{e}$ outros resíduos insolúveis. Segue então a precipitação do alumínio pela mudança de $\mathrm{pH}$ através da passagem de $\mathrm{CO}_{2}$ pela solução. Em seguida, o hidróxido formado é aquecido a $1200^{\circ} \mathrm{C}$ para formação de $\alpha-\mathrm{Al}_{2} \mathrm{O}_{3}{ }^{56}$.

Quando calcinada, a alumina pode apresentar 7 fases cristalográficas distintas, entretanto sua aplicação estrutural é limita basicamente à fase $\alpha$ ( $\alpha$ $\mathrm{Al}_{2} \mathrm{O}_{3}$ ), também denominada corundum, de estrutura romboédrica. A estrutura da alumina consiste de planos compactos de íons oxigênio empilhados na sequência $A-B-A-B$ formando um arranjo hexagonal compacto dos ânions. Os cátions são 
posicionados nos sítios octaédricos do arranjo e formam outro tipo de plano empacotado, inserido entre as camadas de oxigênio. Entretanto, para manter a neutralidade, apenas dois terços dos sítios octaédricos são ocupados. A FIG. 3.5.2.1.1 ilustra o empacotamento do $A l$ e $O$ no plano basal ${ }^{56}$.

Desde que os sítios octaédricos não ocupados apresentem arranjo hexagonal regular, três diferentes planos de cátions podem ser definidos dependendo da posição das lacunas. $A$ estrutura da $\alpha-\mathrm{Al}_{2} \mathrm{O}_{3}$ resulta nos números de coordenação 6 e 4 para o cátion e para o ânion respectivamente ${ }^{56}$.

Apesar da estabilidade da estutura da $\alpha-\mathrm{Al}_{2} \mathrm{O}_{3}$, outras fases metaestáveis, ou de transição, são comumente presentes à temperatura ambiente devido às suas baixas energias de superfície. As estruturas de transição mais comumente estudadas na literatura são a $\mathrm{Y}-\mathrm{Al}_{2} \mathrm{O}_{3}$ e $\theta-\mathrm{Al}_{2} \mathrm{O}_{3}$ de estruturas tetragonal e monoclínica, respectivamente, formas policristalinas com alta área de superfície específica e propriedades estruturais e aplicações bastante diferenciadas da $\alpha$ $\mathrm{Al}_{2} \mathrm{O}_{3}{ }^{56}$. Essas formas metaestáveis são formadas a partir de hidróxidos de alumínio submetidos à calcinação em temperaturas inferiores à $1000^{\circ} \mathrm{C}$. $\mathrm{O}$ aquecimento subseqüente possibilita a formação da $\alpha-\mathrm{Al}_{2} \mathrm{O}_{3}{ }^{57}$.

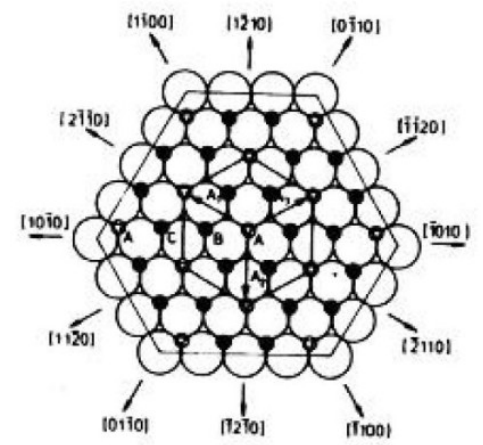

FIGURA 3.5.2.1.1 - Empacotamento do íons Al e O no plano basal. A camada superior de íons $O$ não é mostrada. Vetores e direções da célula hexagonal estão indicados ${ }^{56}$. 
Cerâmicas com alto teor de alumina para aplicações odontológicas são constituídas por, no mínimo, 95\% deste óxido. Os componentes confeccionados são processados a partir de finos pós, prevendo a contração que ocorrer durante a sinterização. Durante o crescimento dos grãos forma-se uma estrutura cristalina entrelaçada de resistência mecânica considerável (até $800 \mathrm{MPa}$ ). Os constituintes, processos de sinterização e a migração dos átomos distinguem claramente as cerâmicas Vitadur ${ }^{\circledR}$ e In-Ceram ${ }^{\circledR}$, uma vez que os espaços entre os cristais de alumina são preenchidos por matriz vítrea neste último. Alumina sinterizada foi originalmente utilizada em odontologia restauradora na forma de pinos pré-fabricados para a confecção de coroas e próteses parcial fixas pequenas, como descrito por McLean e Hughes ${ }^{34}$. Por exemplo, o pino préfabricado com alto teor de alumina era inicialmente cimentado como um núcleo de reforço a uma infraestrutura de ouro. Um conceito bastante semelhante, usado hoje em dia, faz referência às próteses sobre implantes. Até pouco tempo, não era possível a confecção de coroas de porcelana com alto teor de alumina, devido aos problemas derivados de sua contração ${ }^{31}$. Só recentemente o controle desta variável foi alcançado, com o uso de tecnologia computadorizada capaz de criar modelos aumentados proporcionalmente com o sistema Procera ${ }$. As FIG. 3.5.2.1.2 e 3.5.2.1.3 representam infraestruturas cerâmicas preparadas por diferentes técnicas.

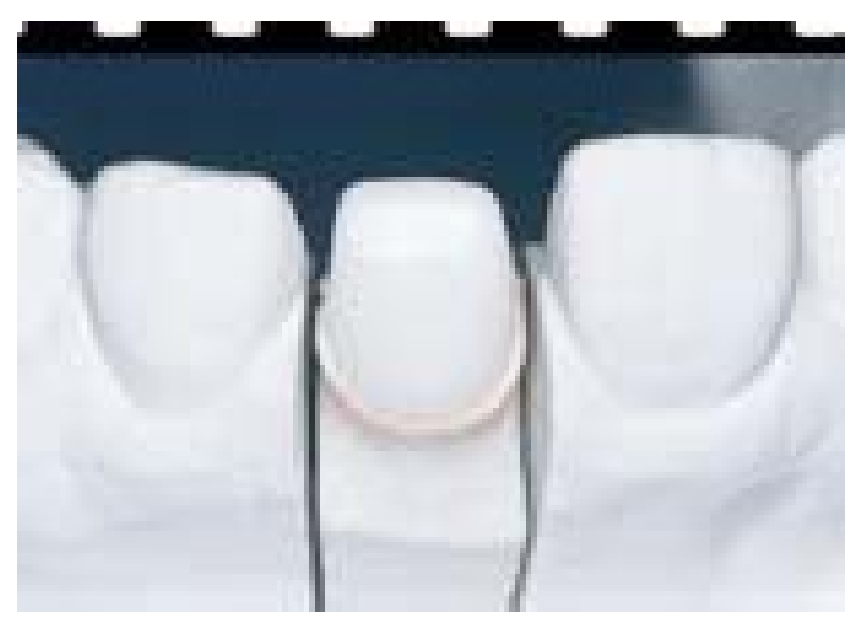

FIGURA 3.5.2.1.2 - Infraestruturas cerâmicas para prótese unitária processada pela técnica slip casting ${ }^{34}$. 


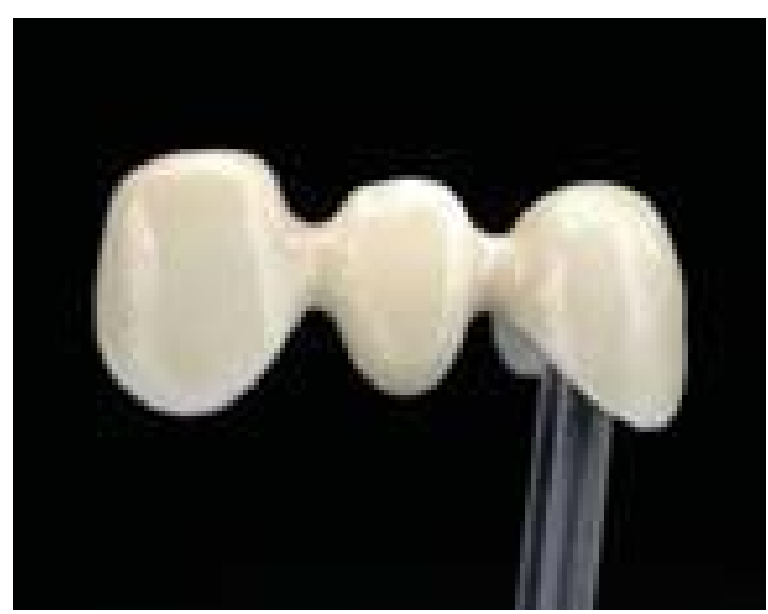

FIGURA 3.5.2.1.3 - Infraestrutura prensada para prótese parcial fixa de três elementos ${ }^{34}$.

\subsubsection{Cerâmicas de zircônia tetragonal policristalina}

A zircônia pode ser obtida a partir de cerca de vinte minerais sendo os mais importantes os relativos ao grupo dos ortossilicatos de zircônio (zirconita), e dióxido de zircônio (badeleíta). Geralmente associado ao háfnio na proporção $\mathrm{Hf} / \mathrm{Zr}=2 \%$ em massa, os minérios de zircônio são submetidos à diversas etapa de purificação química, as quais incluem ataque com hidróxidos de sódio, lixiviação ácida e aquosa e precipitação com sulfato de amônio. Somente para aplicações nucleares há necessidade de separação do háfnio em decorrência dos valores distintos de seção de choque de absorção de nêutrons ${ }^{58}$.

À pressão ambiente, a zircônia apresenta três formas polimórficas em função da temperatura: fase monoclínica na faixa de 25 a $1170^{\circ} \mathrm{C}$; fase tetragonal 
entre 1170 e $2370^{\circ} \mathrm{C}$; e, acima de $2370^{\circ} \mathrm{C}$ até o ponto de fusão, a fase cúbica. $\mathrm{A}$ transformação da fase tetragonal $(t)$ para a fase monoclínica $(m)$, durante resfriamento, ocorre acompanhada de um substancial aumento de volume $(\sim 4,5 \%)$, suficiente para gerar uma fratura catastrófica no material. Essa transformação é reversível e tem início à aproximadamente $950^{\circ} \mathrm{C}$ no aquecimento. A expansão volumétrica decorrente da transformação de fase tetragonal $\rightarrow$ monoclínica, na zircônia pura, pode ser evitada pela estabilização da fase tetragonal e/ou cúbica à temperatura ambiente. Quando estabilizada com a

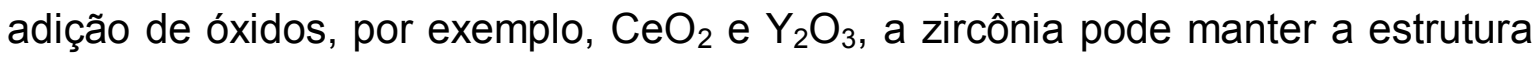
tetragonal à temperatura ambiente e, após controle da tensão induzida pela tranformação $\mathrm{t} \rightarrow \mathrm{m}$, apresenta alta tenacidade e um eficiente mecanismo inibitório de propagação de trincas ${ }^{59}$.

Preconiza-se que a diferença de tamanho entre os cátions de óxidos de estrutura cúbica utilizados como dopante da zircônia, seja de no máximo $40 \%$ do valor do cátion zircônio. A TAB. 3.5.2.2.1 apresenta os dopantes mais utilizados para este caso, seus raios iônicos $(R)$ e a diferença $(D)$ entre o tamanho do cátion dopante e o cátion zircônio ${ }^{60}$. Na TAB. 3.5.2.2.2 apresentam-se algumas informações cristalográficas das estruturas polimórficas da zircônia.

TABELA 3.5.2.2.1 - Valores dos raios iônicos (R) e diferença (D) entre o tamanho do cátion dopante e o do zircônio tetravalente ${ }^{60}$.

\begin{tabular}{ccc}
\hline Elemento & $\mathbf{R}(\mathbf{A})$ & $\mathbf{D}(\%)$ \\
\hline $\mathbf{Z r}{ }^{4+}$ & 0,84 & - \\
\hline $\mathbf{C a}^{2+}$ & 1,12 & +33 \\
\hline $\mathbf{C e}^{4+}$ & 0,97 & +15 \\
\hline $\mathbf{M g}{ }^{2+}$ & 0,89 & +6 \\
\hline $\mathbf{S c}$ & 0,87 & $+3,6$ \\
\hline $\mathbf{S r}^{2+}$ & 1,26 & +5 \\
\hline $\mathbf{Y}^{3+}$ & 1,019 & +21 \\
\hline $\mathbf{Y b}^{3+}$ & 1,125 & +36 \\
\hline $\mathbf{L a}^{3+}$ & 1,16 & +38 \\
\hline $\mathbf{N d}^{3+}$ & 1,109 & +32 \\
\hline $\mathbf{P r}^{3+}$ & 1,126 & +34
\end{tabular}


TABELA 3.5.2.2.2 - Informações cristalográficas das estruturas polimórficas da zircônia $^{63,92}$.

\begin{tabular}{|c|c|c|c|}
\hline Tipo de Estrutura & Monoclínica & Tetragonal & Cúbica \\
\hline Grupo Espacial & $\mathrm{P} 2{ }_{1} / \mathrm{c}$ & $\mathrm{P}_{2} / \mathrm{nmc}$ & Fm3m \\
\hline \multirow[t]{2}{*}{$\begin{array}{l}\text { Parâmetros de } \\
\text { rede }\end{array}$} & $\begin{array}{l}a=5,156 \AA \\
b=5,191 \AA\end{array}$ & $\begin{array}{c}\begin{array}{c}\text { Rede de face } \\
\text { centrada: }\end{array} \\
a=5,094 \AA \\
c=5,177 \AA \\
\end{array}$ & $a=5,124 \AA$ \\
\hline & $\begin{array}{c}c=5,304 \AA \\
\beta=98,9^{\circ}\end{array}$ & $\begin{array}{c}\begin{array}{c}\text { Rede de corpo } \\
\text { centrado: }\end{array} \\
a=3,64 \AA \\
c=5,27 \AA\end{array}$ & \\
\hline Densidade $\left(\mathrm{g} . \mathrm{cm}^{-3}\right)$ & 5,83 & 6,10 & 6,09 \\
\hline
\end{tabular}

À medida que se estreita a diferença de raio iônico entre os cátions dopante e zircônio, uma menor quantidade de dopante é requerida, sendo o processo mais eficiente quanto à estabilização ${ }^{60}$. A solubilidade do dopante escolhido na rede cristalina da zircônia é uma importante característica quando da escolha do elemento estabilizador, já que sua solubilidade deve promover satisfatoriamente a imobilização do cátion via solução sólida ${ }^{60}$.

Para a estabilização da zircônia os óxidos de cério e ítrio, tem-se mostrado eficientes pois além de promoverem satisfatória estabilização de fases, apresenta ampla faixa de estabilização para as fases cúbica e tetragonal e, ainda, apresenta um relativo baixo custo se comparado aos demais óxidos de terras raras ${ }^{61}$.

A característica de maior destaque do diagrama de fases do sistema $\mathrm{ZrO}_{2}-$ $\mathrm{Y}_{2} \mathrm{O}_{3}$ (FIG. 3.5.2.2.1), é a redução da temperatura apresentada para a transformação $\mathrm{t} \rightarrow \mathrm{m}$, conforme é aumentado o teor de ítria, diferindo de outros sistemas existentes. Este fato possibilita melhor aplicabilidade destas cerâmicas uma vez que a aplicação é regida por essa temperatura de transformação ${ }^{62}$. 
A estabilização da fase tetragonal, atingida com a adição de $3 \mathrm{~mol} \%$ de ítria à zircônia, promove o aumento da resistência mecânica e tenacidade à fratura dessas cerâmicas. Os mecanismos que explicam essas propriedades baseiam-se na formação de microtrincas e na transformação de fase induzida por tensão ${ }^{63}$.

A formação de microtrincas ocorre devido à presença de grãos de zircônia tetragonal na matriz, que se transformam para a fase monoclínica durante 0 resfriamento. Esta expansão induz um estado de tensão ao redor da partícula formando microtrincas que absorvem a energia da trinca que se propaga (Figura. 3.5.2.2.2) ${ }^{63}$.

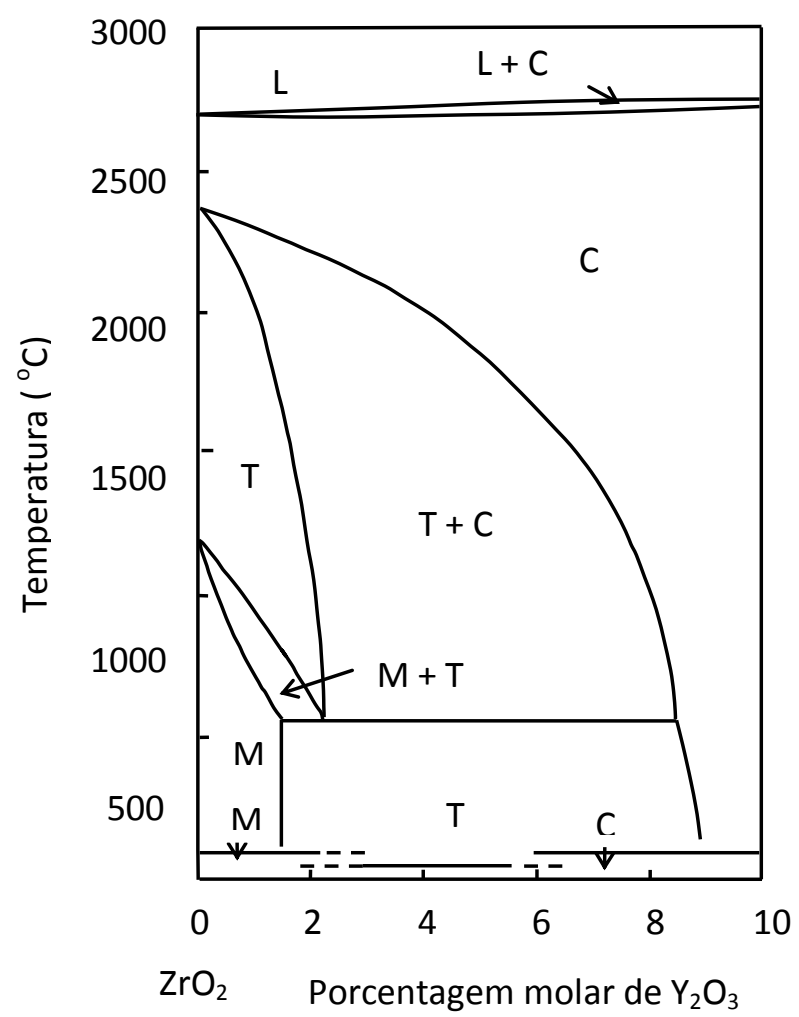

FIGURA 3.5.2.2.1 - Diagrama de fases para o sistema $\mathrm{ZrO}_{2}-\mathrm{Y}_{2} \mathrm{O}_{3}{ }^{63}$. 


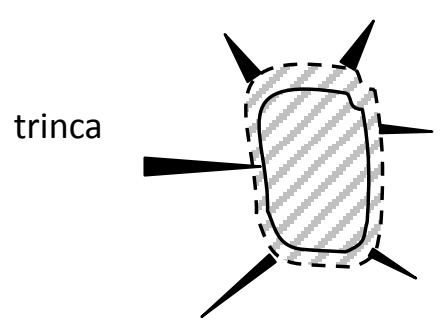

(a)

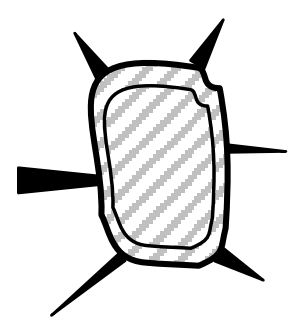

(b)

FIGURA 3.5.2.2.2 - Representação esquemática da formação de microtrincas ao redor de uma partícula de zircônia transformada (a) e a absorção da energia de uma trinca em propagação (b) ${ }^{63}$.

No mecanismo de transformação induzida por tensão, os grãos de zircônia tetragonal são submetidos à compressão pela matriz. Quando a trinca se propaga um campo de tensões induz a transformação para a fase monoclínica. O aumento de volume dos grãos e consequentemente a compressão da matriz, dificulta a propagação da trinca (FIG. 3.5.2.2.3) ${ }^{63}$.

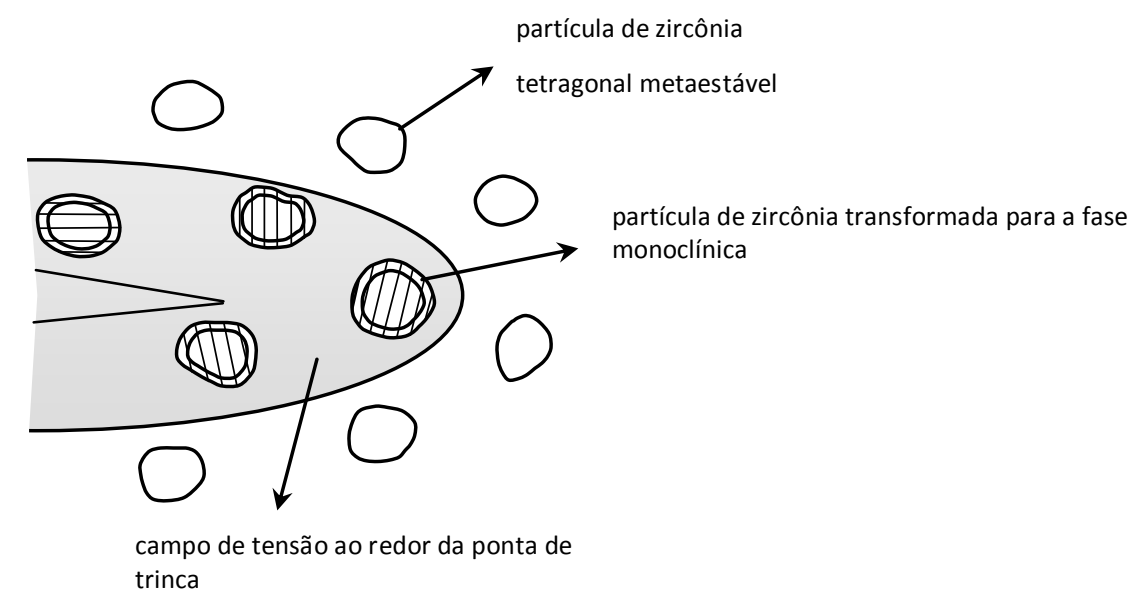

FIGURA 3.5.2.2.3 - Representação esquemática do mecanismo de transformação induzida por tensão ${ }^{63}$.

As propriedades mecânicas da zircônia estabilizada com ítria na fase tetragonal são dependentes de seu tamanho de grão ${ }^{64-65}$. Acima do tamanho de grão crítico $(\sim 1 \mu \mathrm{m})$, a zircônia tetragonal estabilizada com ítria apresenta menor 
estabilidade sendo mais suscetível à transformação espontânea $t \rightarrow m$. Em contrapartida, grãos com tamanho inferior à $0,2 \mu \mathrm{m}$, não permitem essa transformação, reduzindo assim a tenacidade do material 64-65. Conseqüentemente, as condições de sinterização tem forte influência na estabilização e propriedades mecânicas do produto final, já que altas temperaturas e longos períodos de sinterização promovem um maior crescimento dos grãos ${ }^{64-65}$. Atualmente, o uso de temperaturas na faixa entre 1350 e $1550^{\circ} \mathrm{C}$ é recomendado na literatura, já que nesta larga faixa de temperatura foi verificada influencia sobre o tamanho de grão obtido além de maior previsibilidade quanto à estabilização da fase tetragonal da zircônia. Chevalier e colaboradores ${ }^{66}$ demonstraram que a presença de fase cúbica na zircônia não é desejável quando a zircônia tem aplicação biomédica, sendo este fato consequência da desigual distribuição dos íons estabilizadores de ítrio. Enquanto os grãos da fase cúbica apresentam-se enriquecidos de ítrio, seus vizinhos presentes na fase tetragonal apresentam depleção com consequente diminuição da estabilidade.

As principais características das cerâmicas de zircônia estabilizada com ítria na fase tetragonal $\left(\mathrm{ZrO}_{2} / \mathrm{Y}_{2} \mathrm{O}_{3}\right)$, são: densidade $\left(\mathrm{g} / \mathrm{cm}^{3}\right)=6,1$; tamanho médio

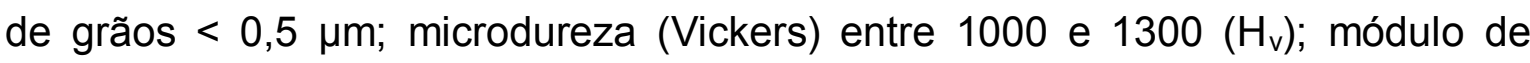
elasticidade $(\mathrm{GPa})=200$; resistência à curvatura $(\mathrm{MPa})=1200$ e resistência à fratura $\mathrm{K}_{\mathrm{lC}}\left(\mathrm{MPa} / \mathrm{m}^{1 / 2}\right)$ entre 9 e 10. A rugosidade de superfície (Ra) situa-se em um intervalo de $0,08-0,18 \mu \mathrm{m}$. Estas características têm possibilitado a confecção de próteses fixas posteriores e a substancial redução na espessura de cobertura da cerâmica, aspectos de muito interesse quando se fala em prótese cerâmica livre de metal. Entretanto, devido à metaestabilidade da zircônia tetragonal, tratamentos superficiais prévios à cimentação adesiva, podem atuar como gatilho da transformação $\mathrm{t} \rightarrow \mathrm{m}$ gerando assim, tensão compressiva na superfície, que apesar de aumentar a resistência à flexão afeta a estabilidade da fase presente aumentado a susceptibilidade ao envelhecimento ${ }^{67-68}$. O envelhecimento a baixas temperaturas da zircônia é um fenômeno recentemente documentado, notavelmente influenciado pela presença de água ${ }^{71-73}$. As conseqüências do 
envelhecimento são múltiplas incluindo degradação superficial e microtrincas que podem comprometer a resistência do material.

À temperatura ambiente e com a adição de estabilizadores, a zircônia é obtida na fase metaestável tetragonal. O envelhecimento consiste na reversão desta fase metaestável para uma fase monoclínica mais estável. Resultados experimentais determinaram alguns parâmetros relevantes quanto à degradação de cerâmicas de zircônia, como: maior velocidade de degradação entre 200 e $300^{\circ} \mathrm{C}$ na presença de vapor d'água; ocorrência de maneira centrípeta; formação de micro e macrotrincas devido à alteração de volume proveniente da transformação $t \rightarrow m$; menor tamanho de grão e maiores concentrações de dopantes retardam a transformação ${ }^{74}$.

Dentre os modelos químicos e mecânicos propostos para explicar o comportamento de envelhecimento das cerâmicas de Y-TZP, destacam-se o mecanismo de corrosão por tensão, onde a perda de resistência está associada ao crescimento lento de trincas de superfície já presentes no material pela corrosão por tensão em água, mecanismo esse exemplificado na FIG. 3.5.2.2.4. Outro modelo aceito, concordante com o anteriormente descrito, afirma que o crescimento da trinca é consequência da redução da energia de superfície pela atmosfera 62, 75 . Com a indução de transformação de fase gerada pelo envelhecimento, o retículo cristalino apresenta uma expansão reversível frente ao tratamento térmico, possivelmente relacionada a inclusão e exclusão de íons $\mathrm{OH}^{-}$. Por apresentar menor carga e tamanho similar, quando comparado à íons $\mathrm{O}^{2-}$, os íons $\mathrm{OH}^{-}$migram mais rapidamente ocupando as vacâncias de oxigênio. Com base nesse argumento, outro mecanismo foi descrito tentanto esclarecer 0 fenômeno de degradação em quatro etapas, conforme a FIG. 3.5.2.2.5. Com a confirmação da interação existente entre o vapor d'água e a ítria da solução sólida formando hidróxido de ítrio, demonstrou que a migração de ítrio para os contornos de grão, confere a essa região comportamento semelhante ao de um núcleo monoclínico, que no caso de crescer além do tamanho crítico devido à migração 
adicional de ítrio, a transformação completa e espontânea do grão tetragonal ocorrerá. Levando em conta a lenta difusão do ítrio na zircônia, esta hipótese não é unânime ${ }^{18,69-70}$.

Guo ${ }^{76}$, propôs em 1999 um mecanismo capaz de explicar satisfatoriamente as observações dos fenômenos presentes durante o mecanismo de degradação, sugerindo que a transformação $t \rightarrow m$ seja decorrente da formação de íons $\mathrm{OH}^{-}$na superfície eliminando as vacâncias de oxigênio. Considerando que existe uma concentração crítica mínima de vacâncias de oxigênio para estabilização da fase tetragonal, ocorre a transformação.

Dentre as várias maneiras de controle da transformação de fase tetragonal $\rightarrow$ monoclinica da zircônia estabilizada com ítria, existentes, as mais adequadas são a formação do compósito alumina-zircônia e a co-dopagem com com céria ${ }^{1,22,72,77-78}$.
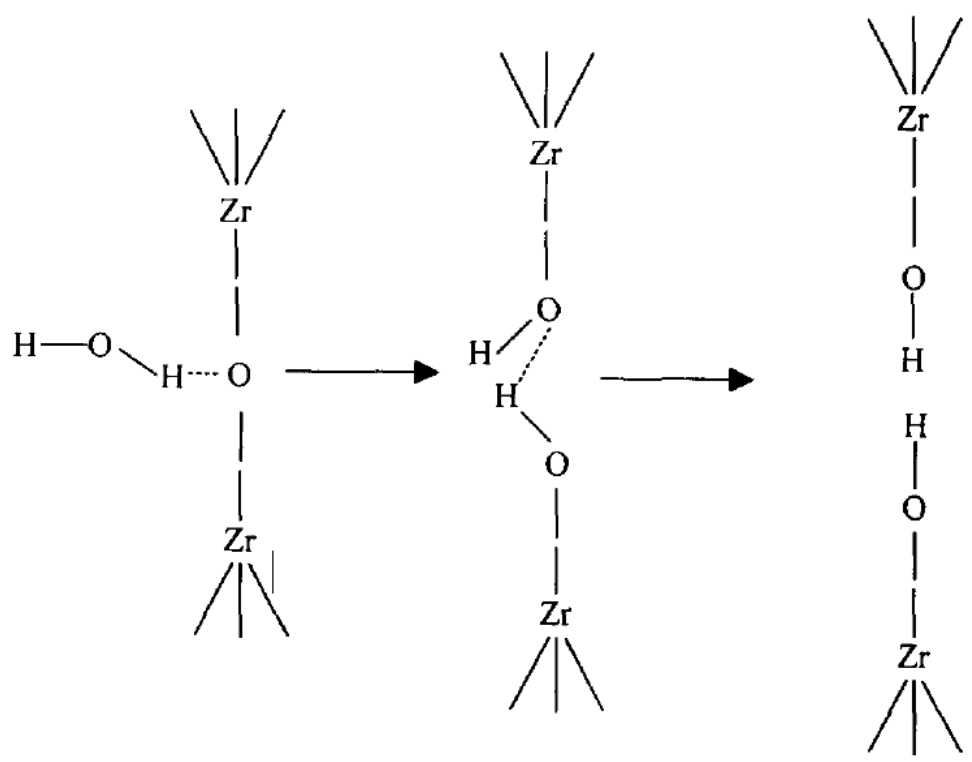

FIGURA 3.5.2.2.4 - Modelo desenvolvido por Sato e colaboradores para explicar o comportamento de degradação da Y-TZP ${ }^{75}$. 

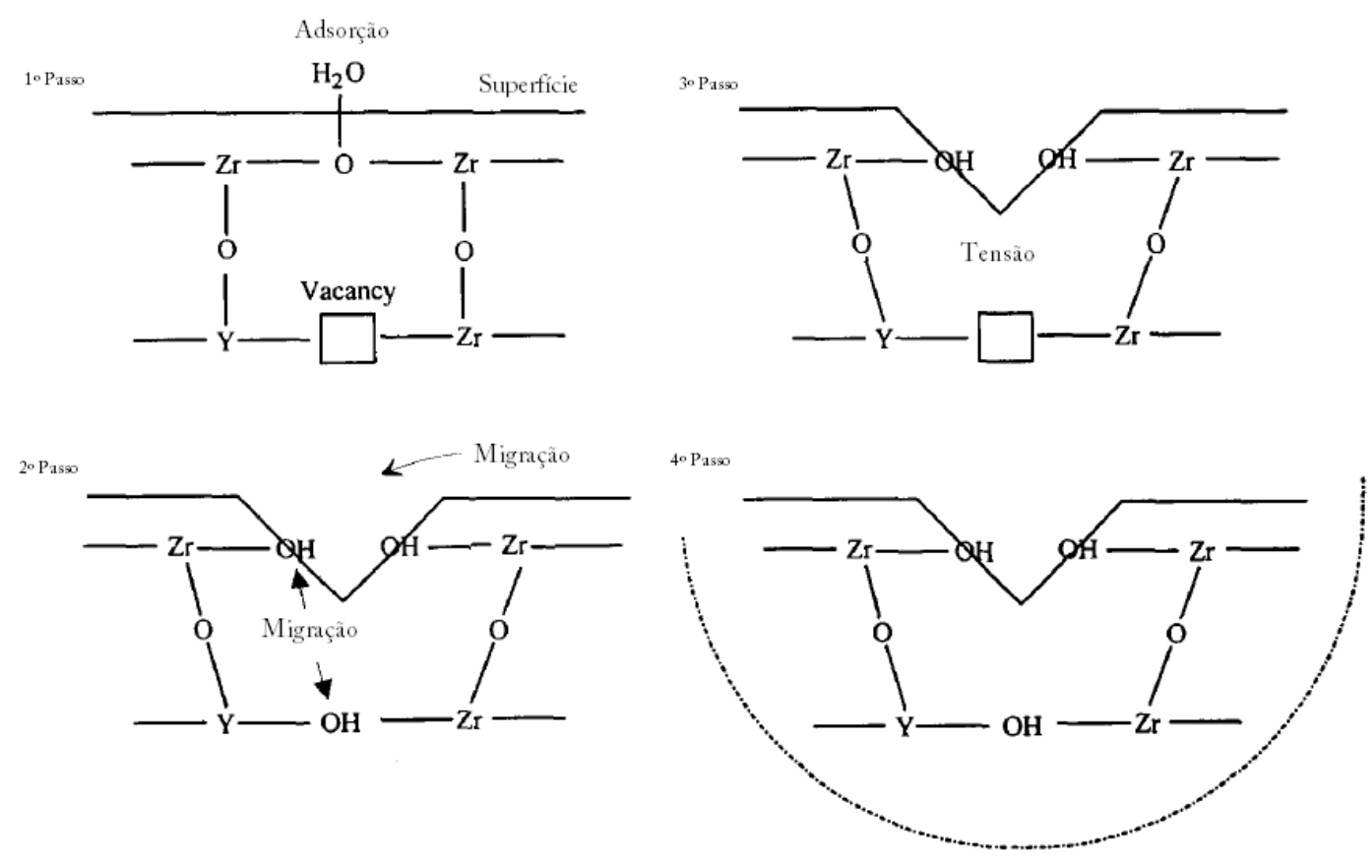

FIGURA 3.5.2.2.5 - Modelo de degradação a baixas temperaturas de cerâmicas do sistema zircônia-ítria, proposto por Yoshimura: (a) adsorção química da água na superfície; (b) formação de ligações $\mathrm{Zr}-\mathrm{OH}$ e $\mathrm{Y}-\mathrm{OH}$ na superfície, criando pontos de tensão; (c) acúmulo de tensões pela migração de íons $\mathrm{OH}^{-}$ na superfície e no retículo; e (d) nucleação da fase monoclínica nos grãos tetragonais, devido à área de deformação nucleada, causando a transformação $t \rightarrow m$ e a formação de micro e macro trincas ${ }^{18}$.

\subsubsection{Cerâmicas infiltradas por vidro}

Este sistema cerâmico é composto por uma cerâmica de infraestrutura infiltrada por vidro e uma cerâmica de cobertura de porcelana feldspática. Inicialmente a infraestrutura é extremamente porosa e constituída de alumina, espinélio ou um compósito de alumina e zircônia. Esta infraestrutura porosa é infiltrada por vidro fundido de aluminoborossilicato de lantânio como fase de 
reforço. Dentre as infraestruturas existentes, a à base de espinélio apresenta maior translucidez do que as contendo alumina ${ }^{79}$.

As principais propriedades das várias cerâmicas comerciais relativas ao sistema cerâmico Vita In-Ceram, são mostradas na TAB. 3.5.2.3.1, na qual também são apresentadas as propriedades das cerâmicas policristalinas. Na TAB. 3.6.2.3.2 são apresentadas as composições dos vidros para cada sistema.

O sistema In-Ceram Alumina é uma infraestrutura constituída por uma fase cristalina de alumina (75\% em massa) e uma fase vítrea (25\%). A conformação deste material é realizada por colagem de barbotinas a partir de uma suspensão de alumina. Após secagem, a peça é pré-sinterizada por 10 horas a $1120^{\circ} \mathrm{C}$. Na etapa seguinte, a infraestrutura resultante, que apresenta baixa resistência mecânica (6-10 MPa) devido à estrutura porosa, é infiltrada por vidro de lantânio aluminoborossilicato a $1100^{\circ} \mathrm{C}$, por 4 a 6 horas $^{13,40}$. Garante-se, desta forma, a obtenção de uma cerâmica de alta densidade, com baixas taxas de retração e valores de resistência à flexão entre 300-600 MPa, em temperaturas relativamente baixas de processamento ${ }^{6,80-81}$.

O sistema In-Ceram Zirconia é constituído por um menor teor de alumina (67\% em massa), compensado pela adição de zircônia tetragonal estabilizada com $12 \mathrm{~mol} \%$ de céria, proporcionando uma aumento na resistência do material à propagação de trincas, e valores de resistência à flexão da ordem de $700 \mathrm{MPa}^{13}$, 40. As condições de processamento da infra-estrutura e de infiltração da fase vítrea segue o mesmo procedimento do In-Ceram Alumina. 
TABELA. 3.5.2.3.1 - Resumo das principais propriedades das cerâmicas odontológicas comerciais relativas ao sistema Vita InCeram $^{41}$.

\begin{tabular}{|c|c|c|c|c|c|}
\hline \multirow[t]{2}{*}{$\begin{array}{l}\text { Propriedades } \\
\text { químicas e físicas }\end{array}$} & \multicolumn{3}{|c|}{$\begin{array}{l}\text { Cerâmicas infiltradas por fase } \\
\text { vítrea }\end{array}$} & \multicolumn{2}{|c|}{$\begin{array}{l}\text { Cerâmicas } \\
\text { policristalinas }\end{array}$} \\
\hline & Espinélio & Alumina & Zircônia & Alumina & Zircônia \\
\hline $\begin{array}{c}\text { Composição da } \\
\text { fase cristalina (\% } \\
\text { em massa) }\end{array}$ & $\begin{array}{c}100 \% \\
\mathrm{MgAl}_{2} \mathrm{O}_{4}\end{array}$ & $\begin{array}{l}100 \% \\
\mathrm{Al}_{2} \mathrm{O}_{3}\end{array}$ & $\begin{array}{c}67 \% \mathrm{Al}_{2} \mathrm{O}_{3} \\
33 \% \mathrm{Ce}- \\
\text { TZP }\end{array}$ & $\begin{array}{l}100 \% \\
\mathrm{Al}_{2} \mathrm{O}_{3}\end{array}$ & $\begin{array}{l}100 \% \mathrm{Y}-\mathrm{TZP} \\
<3 \% \mathrm{Al}_{2} \mathrm{O}_{3}\end{array}$ \\
\hline $\begin{array}{c}\text { Composição final } \\
\text { da cerâmica } \\
\text { (\% em massa) }\end{array}$ & $\begin{array}{c}78 \% \mathrm{MgAl}_{2} \mathrm{O}_{4} \\
22 \% \text { fase } \\
\text { vítrea }\end{array}$ & $\begin{array}{l}75 \% \mathrm{Al}_{2} \mathrm{O}_{3} \\
25 \% \text { fase } \\
\text { vítrea }\end{array}$ & $\begin{array}{c}56 \% \mathrm{Al}_{2} \mathrm{O}_{3} \\
24 \% \mathrm{Ce}- \\
\text { TZP } \\
20 \% \text { fase } \\
\text { vítrea }\end{array}$ & & $<1 \% \mathrm{SiO}_{2}$ \\
\hline $\begin{array}{c}\text { Densidade da } \\
\text { cerâmica } \\
\left(\mathrm{g} . \mathrm{cm}^{-3}\right)\end{array}$ & 3,57 & 3,84 & 4,24 & 3,94 & 6,05 \\
\hline $\begin{array}{l}\text { Resistência à } \\
\text { flexão (MPa) }\end{array}$ & 400 & 500 & 600 & $>500$ & $>900$ \\
\hline $\begin{array}{c}\text { Tenacidade à } \\
\text { fratura (MPa.m }{ }^{-1 / 2} \text { ) }\end{array}$ & 2,7 & 3,9 & 4,4 & 3,5 & 5,9 \\
\hline $\begin{array}{l}\text { Módulo de Young } \\
\text { (GPa) }\end{array}$ & 185 & 280 & 258 & 380 & 210 \\
\hline $\begin{array}{c}\text { Coeficiente de } \\
\text { expansão térmica } \\
\left(20-500^{\circ} \mathrm{C}\right) 10^{-6} \mathrm{~K}^{-1}\end{array}$ & 7,7 & 7,4 & 7,8 & 7,3 & 10,5 \\
\hline $\begin{array}{c}\text { Solubilidade } \\
\text { química (ISO } \\
6872 \text { ) } \\
\mu \mathrm{g} . \mathrm{cm}^{-2}\end{array}$ & 1025 & 1115 & 1118 & $<20$ & $<20$ \\
\hline
\end{tabular}

A alumina e os cristais de espinélio limitam a propagação de trincas, enquanto a infiltração de vidro reduz a porosidade, chegando a exibir resistência a flexão de $450 \mathrm{MPa}$, no caso do sistema contendo alumina. Devido à densidade e lisura superficial atingida, o fabricante recomenda o tratamento da superfície por jateamento com sílica e sua cimentação com um cimento resinoso, afim de proporcionar capacidade de adesão à peça cerâmica e excelente adaptação marginal, associados a alta estética propiciada pelo sistema ${ }^{79}$. Apresentam-se na TAB. 3.5.2.3.3 as frações volumétricas que compõem as cerâmicas à base de 
alumina e zircônia infiltradas com vidro de aluminoborossilicato de lantânio, conformadas por colagem de barbotinas e prensagem ${ }^{46,53}$.

TABELA. 3.5.2.3.2 - Composição das fases vítreas relativas ao sistema Vita InCeram $^{41}$.

\begin{tabular}{|c|c|c|c|c|c|c|c|c|c|c|c|}
\hline \multirow{2}{*}{$\begin{array}{l}\text { Cerâmic } \\
a\end{array}$} & \multicolumn{11}{|c|}{ Composição (\% em massa) } \\
\hline & $\begin{array}{c}\mathrm{Al}_{2} \mathrm{O} \\
3\end{array}$ & $\begin{array}{c}\mathrm{SiO} \\
2\end{array}$ & $\begin{array}{c}\mathrm{B}_{2} \mathrm{O} \\
3\end{array}$ & $\begin{array}{c}\mathrm{TiO} \\
2\end{array}$ & $\begin{array}{c}\mathrm{Bi}_{2} \mathrm{O} \\
3\end{array}$ & $\begin{array}{c}\mathrm{Ca} \\
\mathrm{O}\end{array}$ & $\begin{array}{c}\mathrm{Mg} \\
\mathrm{O}\end{array}$ & $\begin{array}{c}\mathrm{La}_{2} \mathrm{O} \\
3\end{array}$ & $\begin{array}{c}\mathrm{CeO} \\
2\end{array}$ & $\begin{array}{c}\mathrm{Y}_{2} \mathrm{O} \\
3\end{array}$ & $\begin{array}{c}\mathrm{ZrO} \\
2\end{array}$ \\
\hline Espinélio & $\begin{array}{l}16- \\
20\end{array}$ & $\begin{array}{l}14- \\
19\end{array}$ & $\begin{array}{c}10- \\
14\end{array}$ & $4-8$ & $3-7$ & - & $2-4$ & $27-33$ & - & $8-12$ & - \\
\hline Alumina & $\begin{array}{l}14- \\
17\end{array}$ & $\begin{array}{c}14- \\
17\end{array}$ & $\begin{array}{c}12- \\
15\end{array}$ & $3-5$ & - & $2-4$ & - & $39-48$ & $2-5$ & - & - \\
\hline Zircônia & $\begin{array}{l}14- \\
18\end{array}$ & $\begin{array}{c}14- \\
18\end{array}$ & $\begin{array}{c}11- \\
15\end{array}$ & $2-7$ & - & $4-8$ & - & $25-30$ & $6-10$ & $2-6$ & $1-4$ \\
\hline
\end{tabular}

TABELA 3.5.2.3.3 - Frações volumétricas das fases e porosidade que compõem as cerâmicas à base de alumina e zircônia com infiltração de fase vítrea conformadas por colagem de barbotinas e prensagem ${ }^{46,53}$.

\begin{tabular}{lcccc}
\hline \multirow{2}{*}{ Constituinte } & \multicolumn{4}{c}{ Fração volumétrica (\%) } \\
\cline { 2 - 5 } & IA colagem & IA prensagem & IZ colagem & IZ prensagem \\
\hline Alumina & $68,0 \pm 2,1$ & $67,0 \pm 1,9$ & $33,8 \pm 1,2$ & $35,5 \pm 1,7$ \\
\hline Zircônia & - & - & $34,0 \pm 1,5$ & $32,2 \pm 1,2$ \\
\hline Fase vítrea & $27,0 \pm 1,7$ & $29,0 \pm 2,0$ & $23,0 \pm 0,9$ & $21,5 \pm 0,7$ \\
\hline Porosidade & $5,0 \pm 1,1$ & $4,0 \pm 0,9$ & $8,0 \pm 1,1$ & $11,0 \pm 1,3$ \\
\hline
\end{tabular}

$\mathrm{IA}=$ In-Ceram Alumina (Vita-Zahnfabrik) $\quad \mathrm{IZ}=$ In-Ceram Zirconia (Vita-Zahnfabrik) 


\subsection{Tratamento de superfície da infraestrutura cerâmica}

Para o sucesso clínico de restaurações dentais totalmente cerâmicas, é necessário que haja adesão confiável entre a superfície interna da infraestrutura cerâmica, o agente cimentante e superfície dentária a ser reabilitada. Neste sentido, sistemas de cimentação à base de resina, conhecidos comercialmente como cimentos resinosos, têm sido indicados. A superfície interna da restauração em cerâmica deve ser susceptível a um tratamento de superfície que promova retenções micromecânicas. O procedimento usual para o sistema à base de dissilicato de lítio (IPS Empress), tem sido o condicionamento com ácido fluorídrico a $10 \%$ por 20 segundos, seguido da silanização. O condicionamento ácido promove irregularidades na superfície cerâmica desse sistema pela dissolução seletiva dos cristais de leucita e da matriz vítrea ${ }^{84}$.

Atualmente, o processo de união das cerâmicas feldspáticas (à base de sílica e com baixo teor de alumina), aos sistemas adesivos para cimentação (agente de união e cimentos resinosos), parece estar bem estabelecido, visto que a união é proporcionada pelo condicionamento com ácido fluorídrico, potencializada pelo agente silano. Ambos têm a propriedade de aumentar a molhabilidade do cimento, facilitando o contato desses cimentos na superfície cerâmica. Além disso, o silano desempenha função de ligação entre a sílica contida na cerâmica e a matriz orgânica dos cimentos resinosos através de uniões siloxanas ${ }^{84-87}$. A adesão de compostos resinosos a cerâmicas para infraestrutura, à base de feldspato, leucita ou dissilicato de lítio é realizada através de ataque superficial com ácido hidrofluorídrico. O ácido hidrofluorídrico ataca a fase vítrea criando uma superfície retentiva para que ocorra adesão micro mecânica enquanto o silano promove adesão química entre a sílica presente na infraestrutura cerâmica e os radicais metacrilato do cimento resinoso ${ }^{88}$. 
O condicionamento com ácido fluorídrico ou sulfúrico, assim como a silanização, não têm sido eficazes em proporcionar união entre cerâmicas aluminizadas com baixo teor de sílica aos cimentos resinosos. Estudos têm comprovado esta ineficácia, a curto e longo prazo, pela incapacidade desses ácidos degradarem a superfície compacta da cerâmica com alto conteúdo de alumina ${ }^{84-87}$. De fato, a melhora das propriedades mecânicas pelo aumento do conteúdo cristalino e redução do conteúdo vítreo, resulta numa cerâmica ácidaresistente e, qualquer tipo de tratamento ácido produz mudanças superficiais insuficientes para uma adequada adesão ao substrato dental ${ }^{89}$.

O jateamento com sílica ou silicatização, é um tratamento de superfície promissor de cerâmicas aluminizadas ${ }^{90-91}$. Uma análise crítica dos trabalhos científicos já realizados indica que os métodos de ensaio para avaliar a resistência de união, cimento-infraestrutura, especialmente o de cisalhamento, apresentam limitações inerentes ao próprio ensaio, colocando em dúvida seus resultados ${ }^{84-88}$. Assim, fundamentando-se na literatura científica, pode-se afirmar que, hoje, o ensaio de microtração é o mais indicado para avaliar a resistência de união cimento/cerâmica, uma vez que a área solicitada durante o ensaio é bastante reduzida ${ }^{84-88}$.

A adesão de compostos resinosos a cerâmicas para infraestrutura, à base de feldspato, leucita ou dissilicato de lítio é realizada através de ataque superficial com ácido hidrofluorídrico. $\mathrm{O}$ ácido hidrofluorídrico ataca a fase vítrea criando uma superfície retentiva para que ocorra adesão micro mecânica enquanto o silano promove adesão química entre a sílica presente na infraestrutura cerâmica e os radicais metacrilato do cimento resinoso ${ }^{88}$.

A habilidade de adesão a múltiplos substratos, a alta resistência mecânica, a insolubilidade em meio oral e seu potencial para mimetizar as cores, fazem dos cimentos resinosos materiais adequados para a cimentação de restaurações 
estéticas livres de metal. São úteis em situações em que as formas de retenção e resistência adequadas dos preparos dentais foram perdidas. Sua técnica de trabalho é bastante sensível e requer cuidado especial por parte do profissional ${ }^{84}$.

Os cimentos resinosos adesivos são normalmente resinas de diacrilato com $20-80 \%$ de partículas inorgânicas de vidro, a maioria delas com menos de $1,0 \mu \mathrm{m}$ de tamanho. Os cimentos resinosos convencionais possuem em sua composição básica o bisfenol glicidil metacrilalto (BIS-GMA); já os cimentos denominados MDP-modificados possuem em sua composição monômeros ácidos fosfatados do tipo 10-Metacriloxidecil dihidrogenio fosfato (MDP) ou 13Metacriloxidecil dihidrogenio fosfato (META13). Os cimentos resinosos fotoativados tem como principal vantagem a fácil utilização e o controle do tempo de trabalho pelo profissional, enquanto o cimento quimicamente ativado sofre uma polimerização mais homogênea, que ocorre também em áreas de pobre acesso à luz para a fotopolimerização. No entanto, alguns trabalhos têm mostrado que os cimentos ativados foto e quimicamente (tipo dual) são mais eficientes que os quimicamente ativados. A busca de uma união verdadeiramente adesiva entre um material restaurador e um substrato passa, necessariamente, pela realização de um ensaio que teste a resistência mecânica dessa propriedade. O teste de microtração foi introduzido por Sano et al..$^{84}$, que justificaram sua validade por ser uma metodologia que provê áreas adesivas menores, relacionadas a valores adesivos mais altos ${ }^{84}$. 


\section{PROCEDIMENTO EXPERIMENTAL}

\subsection{Síntese e processamento cerâmico}

Os pós à base de alumina e zircônia estabilizada, cujas composições são apresentadas na TAB. 4.1.1, foram preparados pela rota de coprecipitação de hidróxidos ${ }^{77-78}$, em meio amoniacal, empregando-se as seguintes matériasprimas:

- solução de oxicloreto de zircônio, obtida pela dissolução do hidróxido de zircônio com pureza 99,5\% em massa de $\mathrm{ZrO}_{2}+\mathrm{HfO}_{2}$, produzido no IPEN;

- cloreto de ítrio, obtido por dissolução do respectivo óxido, com pureza superior a 99,9\% em massa, de procedência Aldrich; e

- Cloreto de alumínio hexaidratado grau PA.

TABELA 4.1.1: Composição dos pós à base de alumina e zircônia, sintetizados pela rota de copreciptação de hidróxidos.

\begin{tabular}{ccc}
\hline \multirow{2}{*}{$\begin{array}{c}\text { Código da } \\
\text { amostra }\end{array}$} & \multicolumn{2}{c}{ Composição (\% em massa) } \\
\cline { 2 - 3 } & $\mathrm{Al}_{2} \mathrm{O}_{3}$ & Y-TZP \\
\hline $\mathrm{AL}$ & 100 & - \\
\hline $\mathrm{ALZ3Y}$ & 70 & 30 \\
\hline Z3Y & - & 100 \\
\hline AL: & alumina \\
ALZ3Y: compósito alumina-zircônia estabilizada com 3mol\% de ítria \\
Z3Y: $\quad$ zircônia estabilizada com 3 mol\% de ítria;
\end{tabular}


A precipitação do hidróxido de alumínio e a coprecipitação dos hidróxidos mistos de zircônio-ítrio e aluminío-zircônio-ítrio, foram realizadas com hidróxido de amônio 3 molar, fixando-se a concentração de óxidos totais na solução de partida em $35 \mathrm{~g} \cdot \mathrm{L}^{-1}$. A solução contendo os íons metálicos foi pulverizada no agente precipitante, fixando-se o $\mathrm{pH}$ em 10.

Os precipitados obtidos foram lavados em duas etapas: primeiramente com água para eliminação de íons cloreto até apresentar-se negativo frente a teste realizado com nitrato de prata $\left(\mathrm{AgNO}_{3}\right)$; em um segundo momento, os precipitados foram lavados com etanol para eliminação de aglomerados fortes. Ainda para esta última finalidade, foi realizado um tratamento dos precipitados por destilação azeotrópica, utilizando-se butanol como solvente orgânico, visando a formação de um azeótropo negativo com ponto de ebulição com a água de $92^{\circ} \mathrm{C}$. A evaporação do butanol remanescente ocorre a $117^{\circ} \mathrm{C}$. Uma vez removida a água para a secagem do precipitado inibi-se a formação de aglomerados fortes derivados de interações do tipo ponte de hidrogênio ou ainda devido ao acúmulo de estática, com temperatura de ebulição mais elevada ${ }^{93}$.

Após secagem a $80^{\circ} \mathrm{C}$ por 24 horas e calcinação a $800^{\circ} \mathrm{C}$, visando a redução do tamanho médio dos aglomerados, os pós foram submetidos à moagem em etanol por 15 horas, em moinho de bolas, e secagem em estufa a $80{ }^{\circ} \mathrm{C}$ por 24 horas. Para atingir a densidade requerida para a infiltração de fase vítrea no corpo cerâmico (70\% DT), a amostra de pó Z3Y também foi calcinada a $950^{\circ} \mathrm{C}$ e a amostra $\mathrm{AL}$ a $1200^{\circ} \mathrm{C}$, esta última seguida de moagem em moinho de alta energia por 15 horas, designada amostra $A L-\alpha$.

A conformação dos pós, na forma de pastilhas de $10 \mathrm{~mm}$ de diâmetro, foi realizada por prensagem uniaxial (50MPa). Por sua vez, a pré-sinterização do corpo a verde foi realizada na faixa de temperatura entre 950 e $1300{ }^{\circ} \mathrm{C}$, com 
taxas de aquecimento até $800^{\circ} \mathrm{C}$ de $10^{\circ} \mathrm{C} / \mathrm{min}$ e acima de $800^{\circ} \mathrm{C}$ até a temperatura de patamar, onde permaneceram por 1 e 2 horas, de $5^{\circ} \mathrm{C} / \mathrm{min}$. Para estudo comparativo a amostra de zircônia dopada com ítria e a amostra contendo alumina em sua composição foram, respectivamente, também sinterizadas a $1500^{\circ} \mathrm{C}$ e $1650^{\circ} \mathrm{C}$, por 1 hora visando a preparação de corpos cerâmicos de elevada densidade.

A fase vítrea para infiltração no corpo cerâmico poroso, cuja composição é apresentada na TAB. 4.1.2, foi preparada por mistura de óxidos em moinho de bolas e meios de moagem de alumina, tratamento térmico a $1250^{\circ} \mathrm{C}$ seguindo a mesma taxa empregada na pré sinterização com patamar de 2 horas, e moagem das fritas obtidas em moinho de bolas com meios de moagem de alumina seguida de desagregação em almofariz de ágata. A infiltração no corpo cerâmico présinterizado foi realizada entre 1100 e $1400^{\circ} \mathrm{C}$ variando-se o tempo de patamar em 1, 2, 3 e 4 horas. Para efeito comparativo, foram obtidos, por mistura de pós, compósitos contendo o pó cerâmico juntamente com o vítreo, que então foram prensados e submetidos a sinterização na faixa de 1100 a $1300^{\circ} \mathrm{C}$ por períodos de 1 a 2 horas. A codificação das amostras preparadas é descrita na TAB. 4.1.3.

TABELA 4.1.2 - Composição da fase vítrea utilizada para infiltração no corpo poroso de alumina, zircônia estabilizada e compósito alumina-zircônia.

Composição dos óxidos constituintes (\% em massa)

\begin{tabular}{ccccccc}
\hline $\mathrm{La}_{2} \mathrm{O}_{3}$ & $\mathrm{SiO}_{2}$ & $\mathrm{Al}_{2} \mathrm{O}_{3}$ & $\mathrm{~B}_{2} \mathrm{O}_{3}$ & $\mathrm{TiO}_{2}$ & $\mathrm{CaO}$ & $\mathrm{CeO}_{2}$ \\
\hline 40 & 20 & 15 & 15 & 3 & 4 & 3 \\
\hline
\end{tabular}


TABELA 4.1.3 - Codificação das amostras cerâmicas à base de alumina e zircônia contendo fase vítrea de alumínioborossilicato de lantânio, preparadas neste trabalho.

Código da amostra

Processo de impregnação da fase vítrea

\begin{tabular}{|c|c|}
\hline $\mathrm{AL}(\mathrm{i})$ & \multirow{3}{*}{$\begin{array}{c}\text { Infiltração no corpo cerâmico pré-sinterizado por } \\
\text { tratamento térmico }\end{array}$} \\
\hline Z3Y (i) & \\
\hline ALZ3Y (i) & \\
\hline \multirow[t]{2}{*}{$\mathrm{V}-\mathrm{AL}(\mathrm{m})$} & \\
\hline & Mistura de pós e sinterização \\
\hline $\mathrm{V}-\mathrm{Z3Y}(\mathrm{m})$ & $(75 \% \text { de fase cristalina e } 25 \% \text { de fase vítrea })^{*}$ \\
\hline$V-\operatorname{ALZ3Y}(\mathrm{m})$ & \\
\hline
\end{tabular}

* cálculo baseado nos dados de fração volumétrica divulgados por Guazzato et al ${ }^{53}$.

O procedimento experimental, acima descrito, é apresentado de forma esquemática no fluxograma da figura 4.1.1, que também inclui a etapa de infiltração da fase vítrea e as técnicas de caracterização empregadas. 


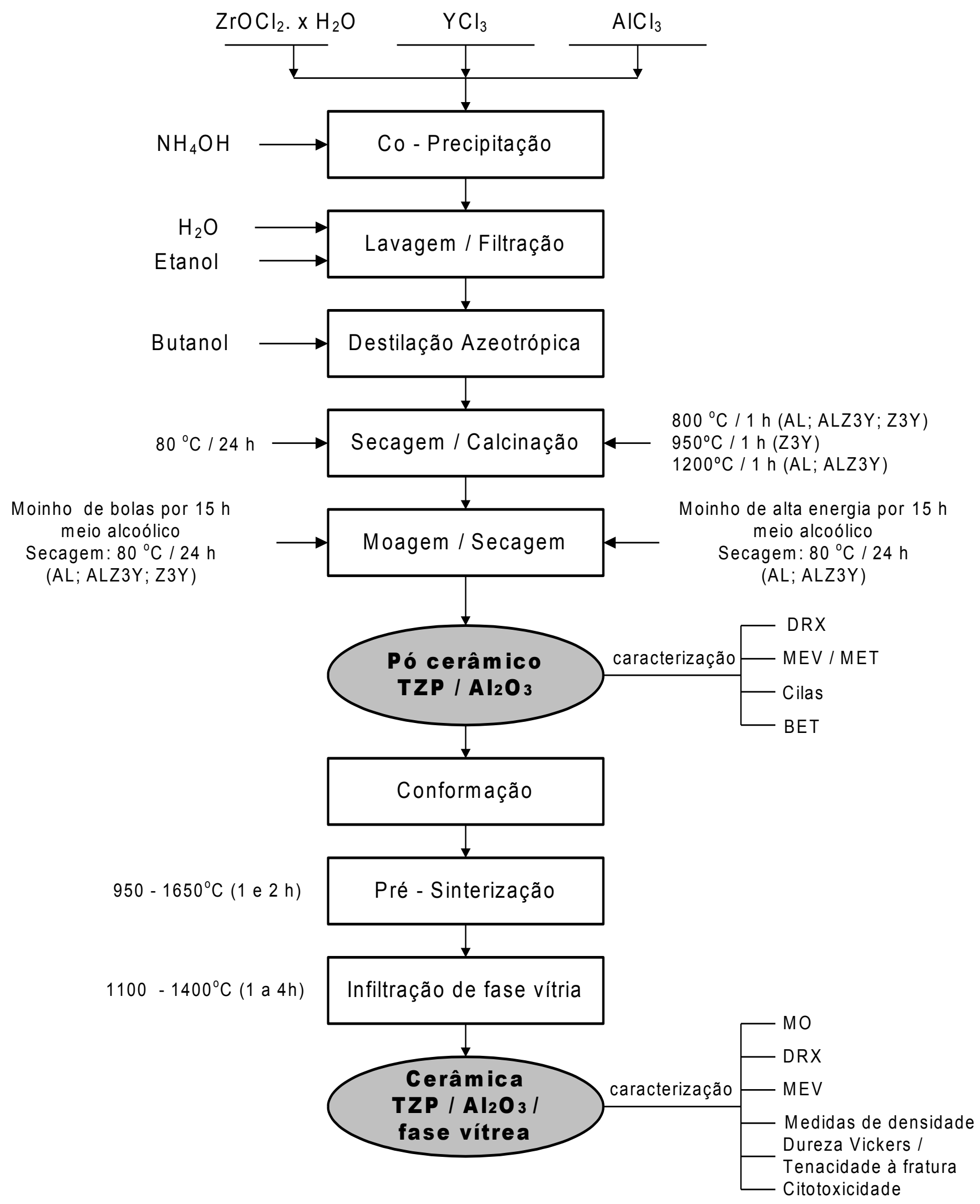

Figura 4.1.1 - Fluxograma esquemático da metodologia adotada para síntese, processamento e caracterização das cerâmicas à base de alumina e zircônia com infiltração de fase vítrea. 


\subsection{Caracterização dos pós}

Os hidróxidos coprecipitados e submetidos à secagem foram caracterizados por análise termogravimétrica e térmica diferencial (Setaram Instrumentations, LABSYS ${ }^{\text {TM }}$ TMA e TGDTA), para observação do comportamento de desidratação e cristalização dos óxidos.

A caracterização química e física dos pós calcinados e moídos foi realizada empregando-se as seguintes técnicas:

- Difração de raios X (Rigaku, mod. Multiflex), utilizando radiação Cu/ka e monocromador de grafite, para análise das fases cristalinas formadas;

- Espalhamento a laser (Cilas Granulometer, mod. 1064), para determinação da distribuição granulométrica dos aglomerados;

- Adsorção gasosa (B.E.T) (BET Quantachrome, Nova 1200), para medidas de área de superfície específica;

- Microscopia eletrônica de varredura (Phillips, mod. XL30), para observação da forma das partículas e dos aglomerados; 
- Microscopia eletrônica de transmissão (Jeol, mod. JEM 2100), para observação da dimensão das partículas.

\subsection{Caracterização do corpo cerâmico a verde}

As amostras compactadas uniaxialmente (50MPa) em matriz de $7,0 \mathrm{~mm}$ de diâmetro foram analisadas por dilatometria (Setaram Instrumentations, LABSYS ${ }^{\text {TM }}$ TMA). Os ensaios foram realizados até temperatura de $1400^{\circ} \mathrm{C}$, empregando-se taxa de aquecimento de $10^{\circ} \mathrm{C} / \mathrm{min}$, em ar atmosférico.

\subsection{Caracterização dos corpos cerâmicos pré sinterizados e infiltrados por vidro}

Para caracterização das amostras sinterizadas foram realizadas as seguintes análises e ensaios:

- Densidade aparente baseada no princípio de Archimedes;

Utilizando-se da equação 4.4.1, foram obtidas as medidas de densidade aparente dos compactos sinterizados e infiltrados por vidro:

$$
\rho_{\text {amostra }}=\frac{M_{s} \times \rho_{\text {água }}}{M_{u}-M_{i}}
$$

Onde,

$\rho=$ densidade $\left(\mathrm{g} \cdot \mathrm{cm}^{-3}\right)$

$M_{S}, M_{\cup}$ e $M_{l}=$ massa da amostra seca, úmida e imersa, respectivamente (g). 
Para determinação da densidade teórica do compósito alumina-zircônia, foi utilizada a regra das misturas (Eq. 4.4.2), já que os resultados obtidos nessa técnica apresentam boa correlação com dados experimentais.

$$
\rho_{\text {compósito }}=\left(\rho_{a} \cdot X_{a}\right)+\left(\rho_{b} \cdot X_{b}\right)
$$

Onde,

$$
\begin{aligned}
& \rho_{\text {compósito }}=\text { densidade teórica do compósito }\left(\mathrm{g} \cdot \mathrm{cm}^{-3}\right) \\
& \rho_{a}=\text { densidade teórica do óxido } A ; \\
& X_{a}=\text { fração volumétrica do óxido } A ; \\
& P_{b}=\text { densidade teórica do óxido } B ; \\
& X_{b}=\text { fração volumétrica do óxido } B \text {. }
\end{aligned}
$$

- Difração de raios X (Rigaku, mod. Multiflex), utilizando radiação Cu/ka e monocromador de grafite, para análise das fases cristalinas formadas;

- Microscopia eletrônica de varredura (Phillips, mod. XL30), para análise microestrutural das superfícies de fratura das cerâmicas pré-sinterizadas e das superfícies polidas das cerâmicas com incorporação de fase vítrea. Nessas amostras também foram realizadas análise semi-quantitativa dos elementos químicos presentes por espectroscopia de energia dispersiva (EDS);

- Dureza e tenacidade à fratura (MicroVickers RS 5112,5114, Buehler);

As medidas de dureza e dimensões das trincas das amostras com incorporação de fase vítrea, cujo corpo a verde foi conformado em matriz de 10 $\mathrm{mm}$, foram realizadas por testes de impressão Vickers. A preparação das amostras incluiu o corte no eixo longitudinal com disco adiamantado, embutimento em baquelite e polimento com pasta de diamante de granulometria 15, 6 e $1 \mu \mathrm{m}$. A 
força aplicada pelo indentador foi determinada por testes na faixa de 10 a $100 \mathrm{~N}$ para as cerâmicas preparadas no presente trabalho.

A dureza do material foi calculada de acordo com a seguinte equação 4.4.3 94.

$$
H_{v}=\frac{x \cdot P}{d^{2}}
$$

Onde,

$$
\begin{aligned}
& H_{v}=\text { dureza Vickers }(G P a) ; \\
& P=\text { força aplicada }(N) ; \\
& d=\text { comprimento da diagonal da impressão }(m) ;
\end{aligned}
$$$$
\text { e } \alpha=1,8544 \text { (penetrador de diamante piramidal - ângulo de inclinação de }
$$
$\left.136^{\circ}\right)$

A determinação da tenacidade à fratura $\left(\mathrm{K}_{\mathrm{IC}}\right)$ foi realizada empregando-se a equação de Evans (Eq. 4.4.4) normalizada por Ponton e Rawlings ${ }^{95-96}$, a qual é adequada para trincas do tipo radial-mediana, observadas nas amostras avaliadas. As representações esquemáticas dos possíveis tipos de trincas observadas nos materiais cerâmicos são apresentadas na FIG. 4.4.1. As trincas do tipo Palmqvist geralmente são obtidas em materiais que apresentam tenacidade à fratura elevada (caso das cerâmicas TZP), quando a força aplicada for relativamente baixa, enquanto as do tipo radial-mediana são observadas em materiais relativamente mais frágeis. A identificação do tipo de trinca é realizada pela observação da indentação em microscópio ótico, após rápido polimento com suspensão de granulometria de $1 \mu \mathrm{m}$. As trincas do tipo radial-mediana diminuem de tamanho, mas não se separam do vértice da indentação, diferenciando-se das trincas Palmqvist. 


$$
\left.K_{I C}=\right), 0824 \frac{P}{C^{3 / 2}}
$$

Onde,

$\mathrm{K}_{\mathrm{IC}}=$ tenacidade à fratura $\left(\mathrm{MPa} \cdot \mathrm{m}^{1 / 2}\right)$;

$\mathrm{P}=$ força aplicada $(\mathrm{N})$;

$a=$ comprimento da semidiagonal de impressão $(m)$;

$\mathrm{I}=$ comprimento da trinca $(\mathrm{m}) ; \mathrm{e} c=\mathrm{a}+\mathrm{I}(\mathrm{m})$

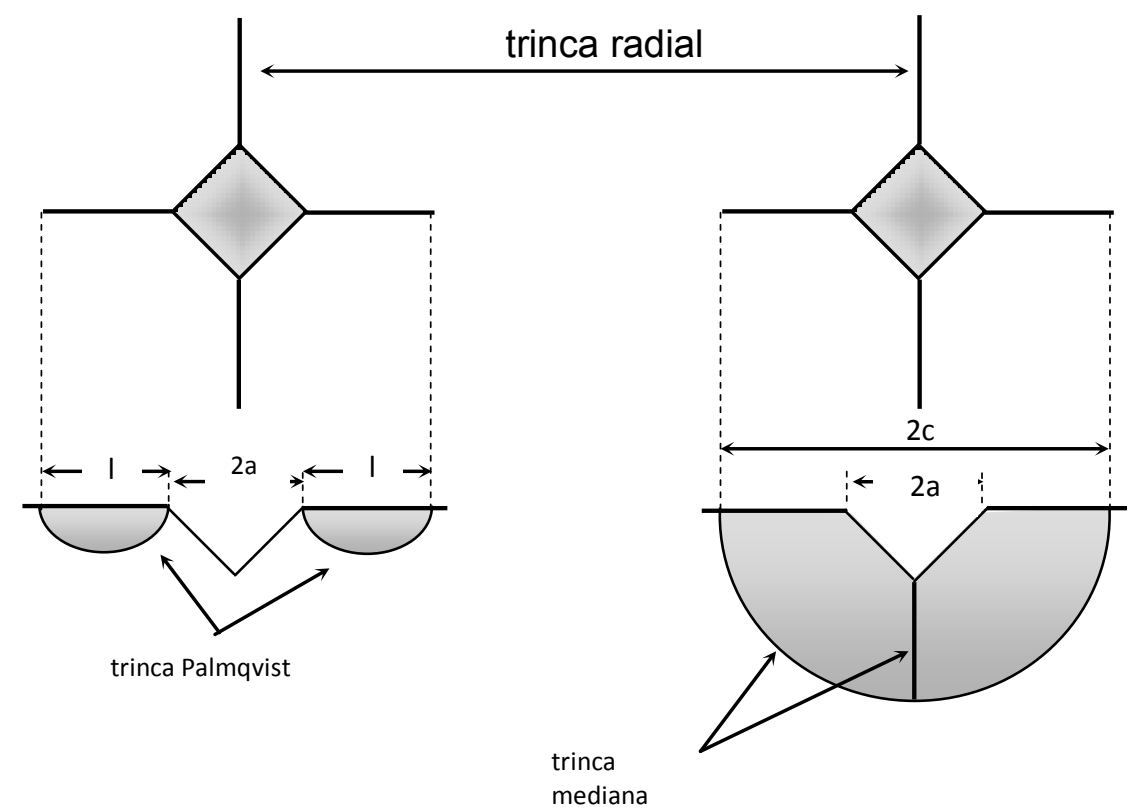

FIGURA 4.4.1 - Desenho esquemático das trincas tipo Palmqvist e radial-mediana 
- Microscopia óptica (Leica DM IRM), para obtenção das imagens das impressões e das trincas após ensaio de dureza Vickers.

\section{- Ensaio de citotoxicidade}

A avaliação da citotoxicidade das amostras $\mathrm{V}-\mathrm{AL}(\mathrm{m}), \mathrm{V}-\mathrm{Z3Y}(\mathrm{m})$ e $\mathrm{V}$ $\operatorname{ALZ3Y}(m)$, preparadas por mistura de pós, foi realizado in vitro com base no procedimento descrito na norma ISO 10993-5 ${ }^{97}$. Utilizou-se como controle positivo uma solução fenólica a $0,3 \%$ e como negativo um pó cerâmico de alumina de alta pureza. Os extratos das amostras cerâmicas previamente esterilizadas (radiação gama $25 \mathrm{kGY}$ ) foram mantidos em contato com meio de cultura RPMI 1640 por $48 \mathrm{~h}$ em estufa a $37^{\circ} \mathrm{C}$ e com atmosfera úmida de $5 \%$ de $\mathrm{CO}_{2}$. A análise espectrofotométrica foi conduzida em uma microplaca de cultura celular contendo diluições crescentes $(6,25 ; 12,5 ; 25 ; 50 ; 100 \%)$ do extrato dos materiais, os materiais de controle e a suspensão de células de ovário de hamster chinês (CHO-K1) nos poços. Feito isso, foi realizada a incubação a $37^{\circ} \mathrm{C}$ da microplaca sob atmosfera úmida de $5 \%$ de $\mathrm{CO}_{2}$. Decorridas $72 \mathrm{~h}$ a mistura de corantes foi adicionada aos poços testes para avaliação da viabilidade celular. 


\section{RESULTADOS E DISCUSSÃO}

A apresentação e discussão dos resultados obtidos no presente trabalho foi dividida em três etapas, iniciando-se pela caracterização dos pós à base de alumina e zircônia sintetizados por coprecipitação de hidróxidos e submetidos a diferentes condições de calcinação e moagem. Utilizando-se esses pós, estudouse a sinterabilidade dos mesmos com o objetivo de se produzir uma matriz porosa com densidade correspondente a $70 \%$ em relação à densidade teórica. $\mathrm{Na}$ terceira fase da pesquisa realizou-se a impregnação da fase vítrea de aluminoborossilicato de lantânio utilizando-se as técnicas de infiltração e mistura de pós. As amostras obtidas foram avaliadas quanto à integridade estrutural, microestrutura, densidade aparente, dureza, tenacidade à fratura e citotoxicidade.

\subsection{Caracterização dos hidróxidos secos}

Os pós sintetizados pela rota de coprecipitação e secos em estufa à $80^{\circ} \mathrm{C}$ por 24 horas, foram caracterizados por análise termogravimétrica (TG) e análise térmica diferencial (ATD). As curvas de TG e ATD dos hidróxidos secos AL, ALZ3Y e Z3Y são apresentadas, respectivamente, nas FIG. 5.1.1.a e 5.1.1.b. Na faixa de temperatura de 35 a $200^{\circ} \mathrm{C}$, observa-se considerável perda de massa, tanto para o compósito, quanto para os hidróxidos de alumínio e de zircônio coprecipitado com ítrio, provavelmente correspondente à perda de água residual e/ou solventes orgânicos utilizados durante a síntese e processamento dos pós cerâmicos. Os picos exotérmicos, os quais são claramente definidos para as amostras Z3Y e ALZ3Y, são atribuídos à cristalização dos hidróxidos a óxidos, enquanto o pico endotérmico característico para a amostra $A L$, possivelmente é atribuído a liberação de água livre e de hidratação (Fig. 5.1.1.b). Em temperaturas superiores a $600^{\circ} \mathrm{C}$ nota-se que a perda de massa torna-se consideravelmente menor. 


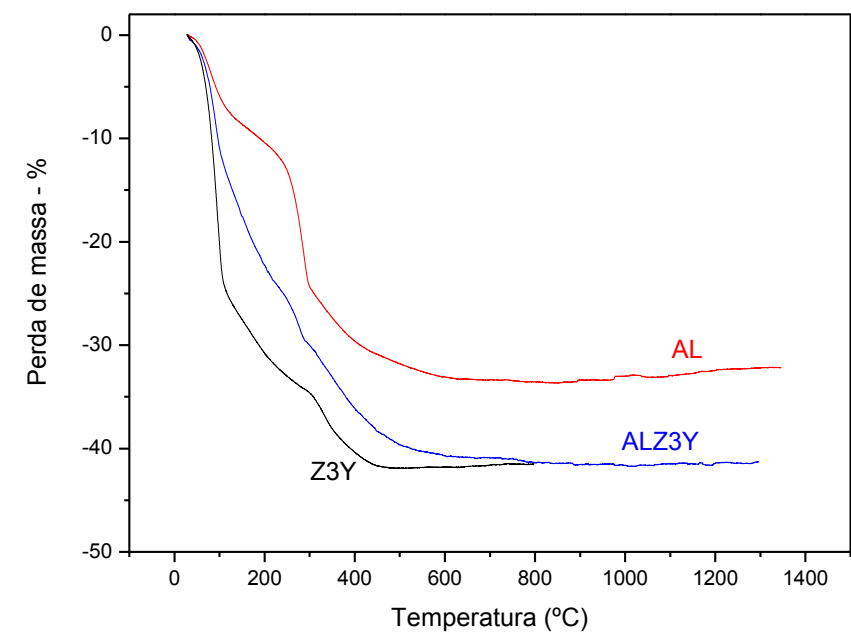

(a)

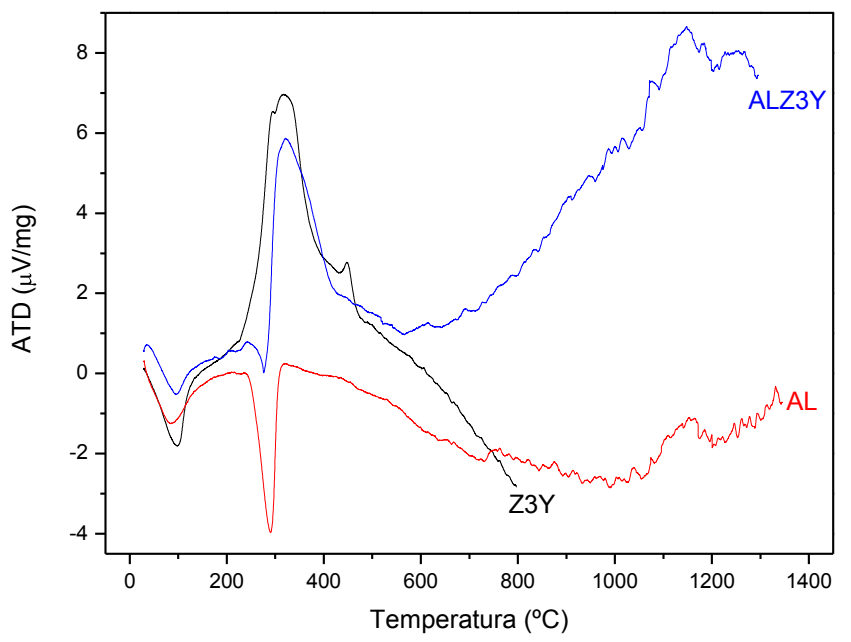

(b)

FIGURA 5.1.1 - Curvas TG (a) e DTA (b), dos hidróxidos secos de alumínio, de zircônio coprecipitado com ítrio e de alumínio coprecipitado com zircônio e ítrio

\subsection{Caracterização dos pós cerâmicos calcinados}

Após síntese e calcinação a 800 e $1200^{\circ} \mathrm{C}$, os pós cerâmicos foram submetidos à análise de adsorção gasosa para determinação da área superficial específica. Os valores obtidos, apresentados na TAB. 5.2.1, evidenciam que a reatividade dos pós de alumina, diminuiu drasticamente com o aumento da temperatura de calcinação $\left(800\right.$ e $1200^{\circ} \mathrm{C}$, respectivamente para as amostras $\mathrm{AL}$ e AL- $\alpha$ ), indicando que a amostra comercial ICA (In-Ceram® alumina) tem em sua composição a $\alpha$-alumina. Fixando-se a temperatura de calcinação em $800^{\circ} \mathrm{C}$, caso das demais amostras, verifica-se que a presença de alumina eleva consideravelmente a área específica dos pós. Esse comportamento já havia sido observado em trabalhos anteriores realizados por Garcia et al. ${ }^{93}$. 
Observando as curvas de distribuição granulométrica apresentadas na FIG. 5.2.1, verifica-se que o tamanho médio dos aglomerados, que constituem o pó, situa-se entre 1 e $4 \mu \mathrm{m}$.

TABELA 5.2.1 - Área superficial específica dos pós sintetizados à base de alumina e zircônia calcinados a $800^{\circ} \mathrm{C}$ por 1 hora e $1200^{\circ} \mathrm{C}$ (amostra AL- $\alpha$ ) e de procedência comercial (amostra ICA)

\begin{tabular}{ccc}
\hline $\begin{array}{c}\text { Código das } \\
\text { amostras }\end{array}$ & $\begin{array}{c}\text { Temperatura/Tempo } \\
\text { de Calcinação }\end{array}$ & Área Superficial Específica $\left(\mathrm{m}^{2} / \mathrm{g}\right)$ \\
\hline $\mathrm{AL}$ & $800^{\circ} \mathrm{C} / 1 \mathrm{~h}$ & 140,8 \\
\hline $\mathrm{AL}-\mathrm{a}$ & $1200^{\circ} \mathrm{C} / 1 \mathrm{~h}$ & 4,5 \\
\hline $\mathrm{AL}-\mathrm{Z3Y}$ & $800^{\circ} \mathrm{C} / 1 \mathrm{~h}$ & 162,5 \\
\hline $\mathrm{Z3Y}$ & $800^{\circ} \mathrm{C} / 1 \mathrm{~h}$ & 66,6 \\
\hline $\mathrm{ICA}$ & Comercial & 2,4
\end{tabular}

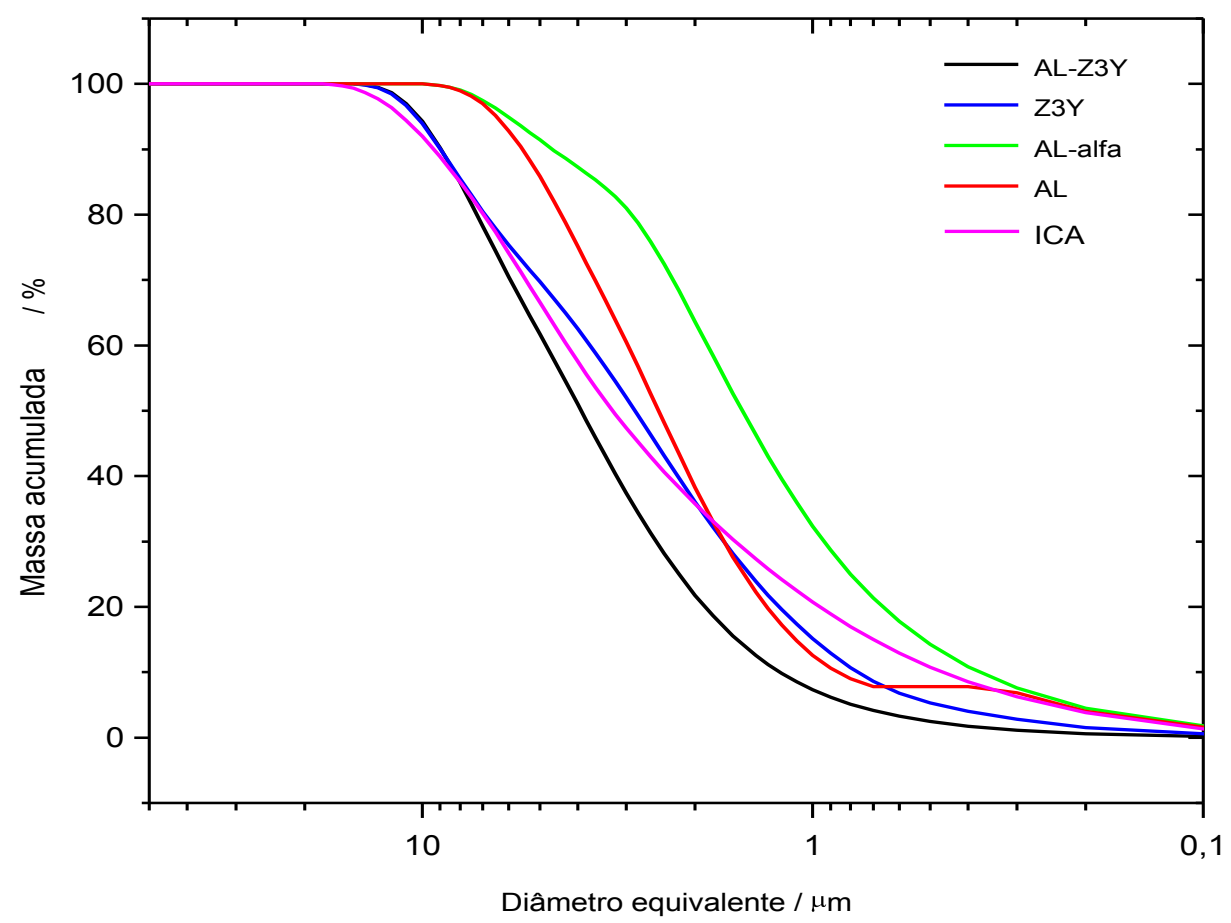

FIGURA 5.2.1 - Distribuição de tamanho de aglomerados dos pós sintetizados à base de alumina e zircônia e de procedência comercial (ICA). 
Menores valores de tamanho médio de aglomerados foram observados para os pós de alumina calcinados a $800^{\circ} \mathrm{C}$ (amostra $\mathrm{AL}$ ), seguida da alumina calcinada a $1200^{\circ} \mathrm{C}(\mathrm{AL}-\alpha)$. Conforme observado nas micrografias da FIG. 5.2.3., os aglomerados relativos aos compósitos de alumina e aos pós de zircônia estabilizada são de maior tamanho, embora também constituídos por partículas de pequena dimensão.

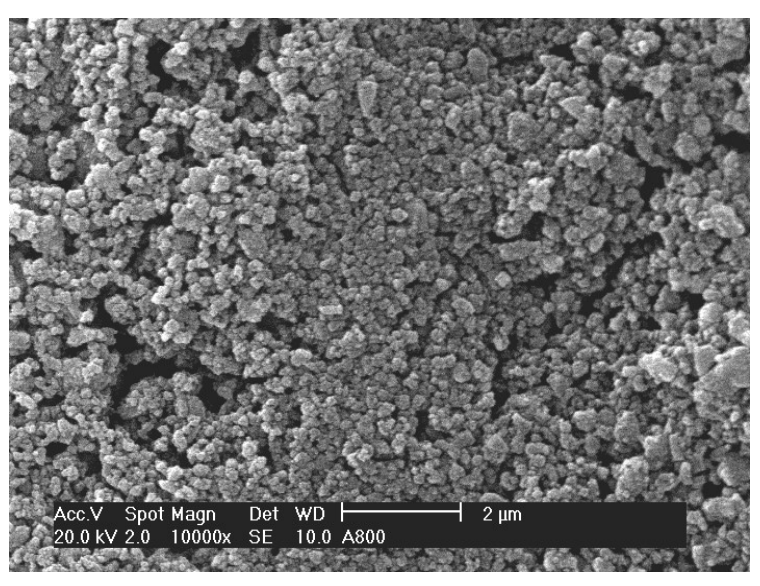

(a)

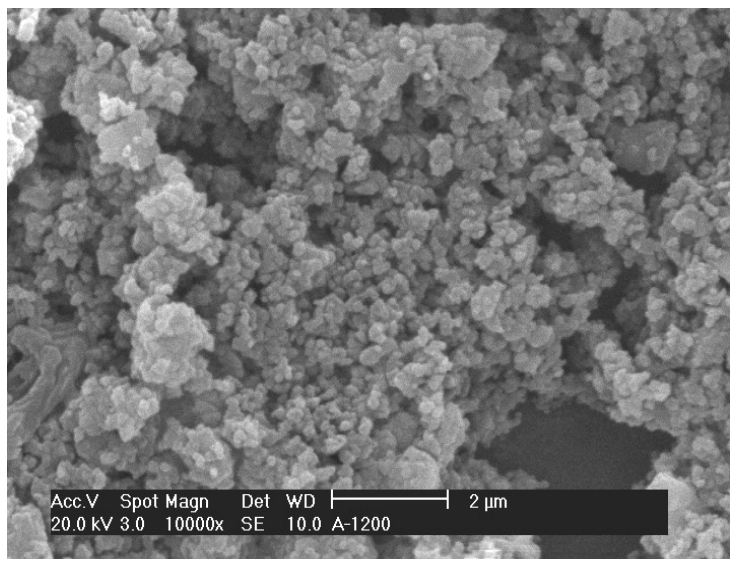

(b)

FIGURA 5.2.2 - Micrografias, obtidas por MEV, de pós de alumina calcinados por 1 hora em diferentes temperaturas: (a) 800C; (b) 1200 ㄷ.

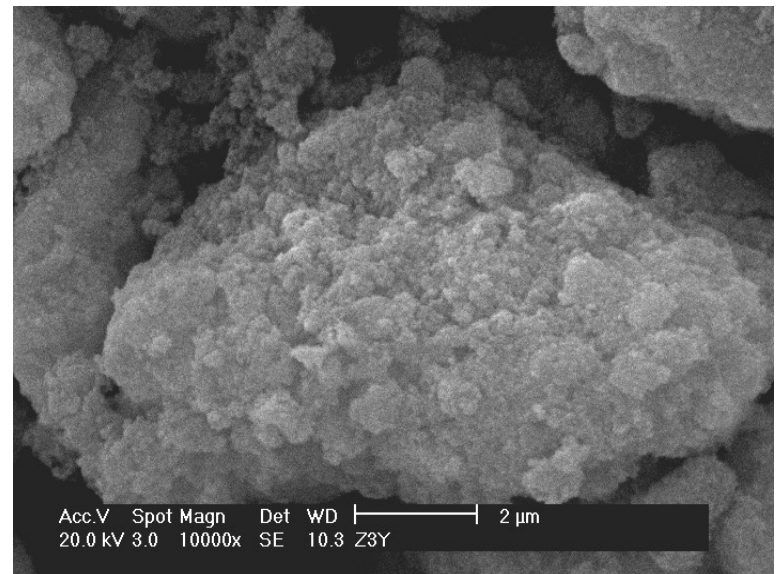

(a)

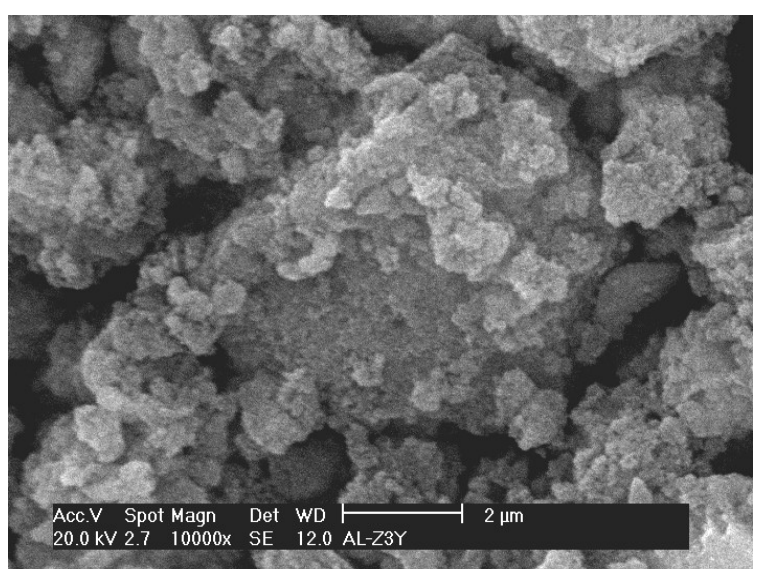

(b)

FIGURA 5.2.3. - Micrografias, obtidas por MEV, de pós de zircônia estabilizada com ítria

(a) e apresentando $70 \%$ em massa de alumina na composição (b). 
Na FIG. 5.2.4 são apresentadas as micrografias dos pós sintetizados, obtidas por microscopia eletrônica de transmissão.
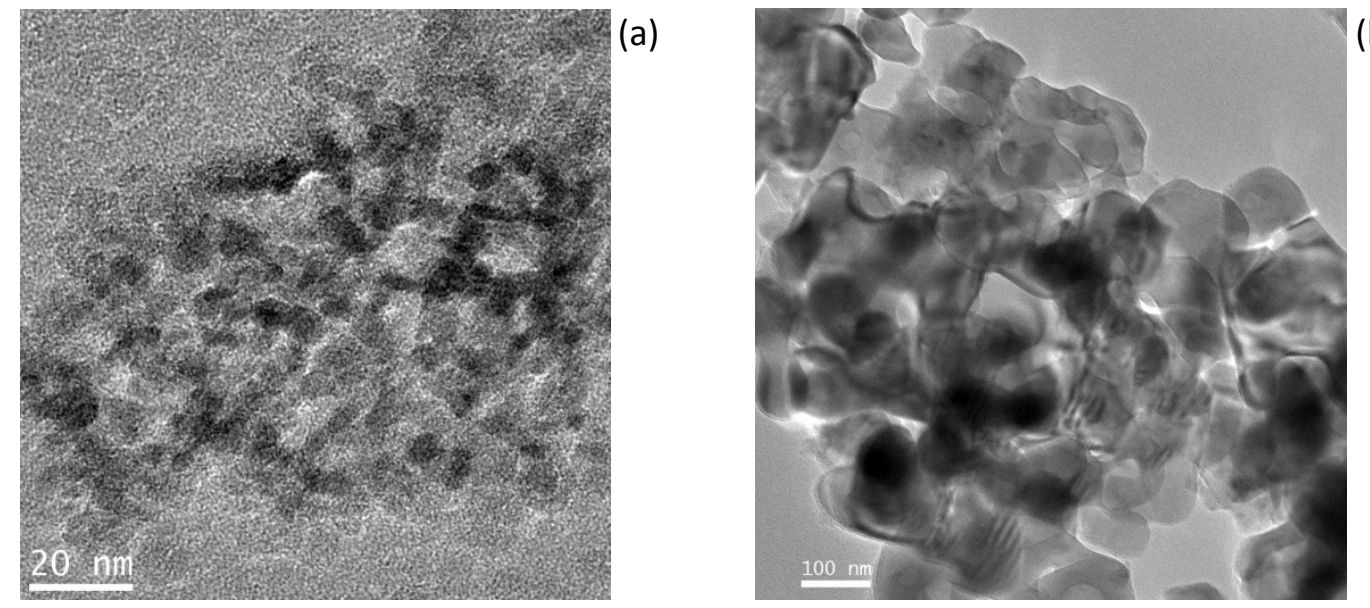

(b)
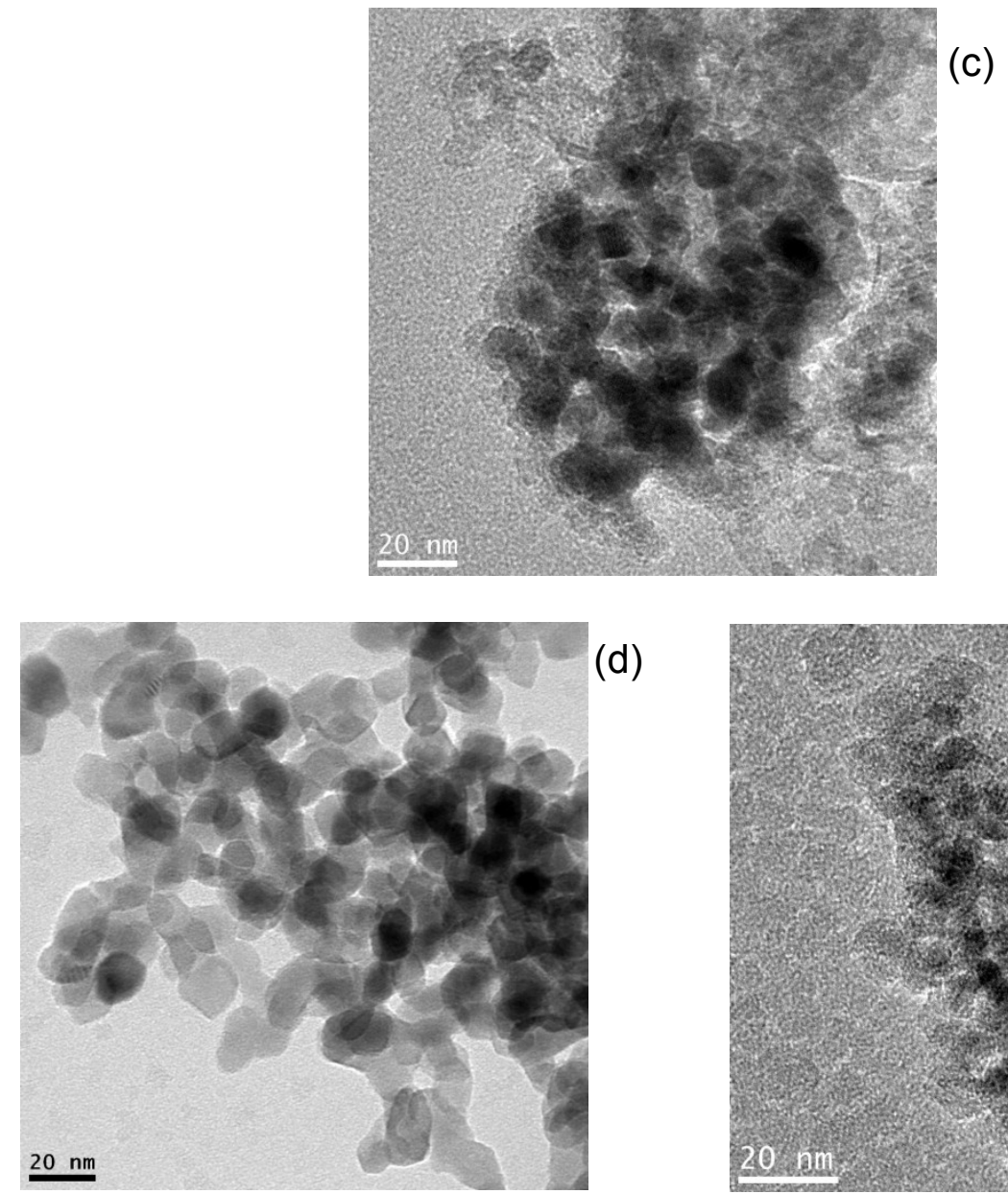

(d)

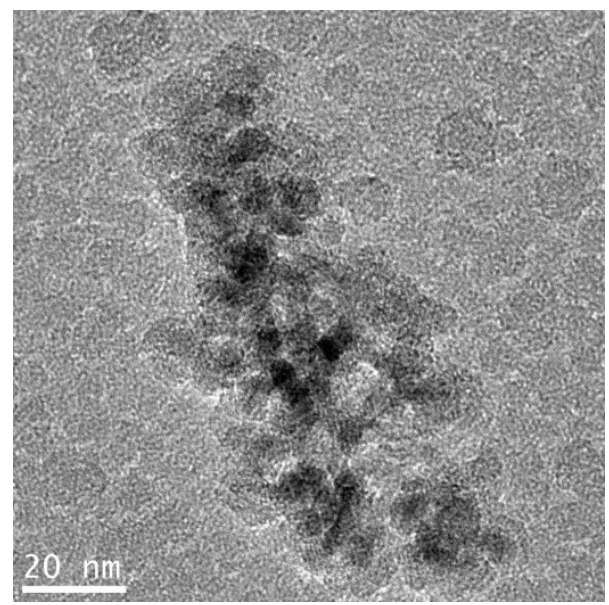

(e)

FIGURA 5.2.4 - Micrografias, obtidas por MET, de pós de alumina, zircônia estabilizada com ítria e compósito alumina-zircônia referentes às seguintes amostras: (a) $A L$; (b) $A L-\alpha$; (c) $A L-\alpha$ após moagem em moinho de alta energia; (d) Z3Y e (e) ALZ3Y. 
Observa-se o tamanho nanométrico das partículas calcinadas, sendo que o aumento de tamanho das partículas ocorre quando se emprega temperaturas mais elevadas de calcinação (caso da amostra $A L-\alpha$ ). Entretanto, após moagem de alta energia, a dimensão do pó $\mathrm{AL}--\alpha$ pode ser reduzida para $20 \mathrm{~nm}$.

Os difratogramas representativos dos pós sintetizados, encontram-se na FIG. 5.2.5. Nota-se que, com exceção da amostra AL- $\alpha$, que foi calcinada a $1200^{\circ} \mathrm{C}$ por 1 hora, as amostras contendo alumina apresentam baixa cristalinidade, uma vez que o pó calcinado a $800^{\circ} \mathrm{C}$ apresenta maior energia livre, devido à sua elevada área superficial. Os dados referentes aos picos mais intensos, identificados para as fases $\alpha$ e $\theta$ da alumina e tetragonal e monoclínica da zircônia, foram extraídos das fichas 11-0661, 35-0121, 42-1164 e 86-1451, respectivamente, do JCPDS-ICCD (Joint Committed Powder on Diffraction Standardt - The International Centre for Diffraction Data).

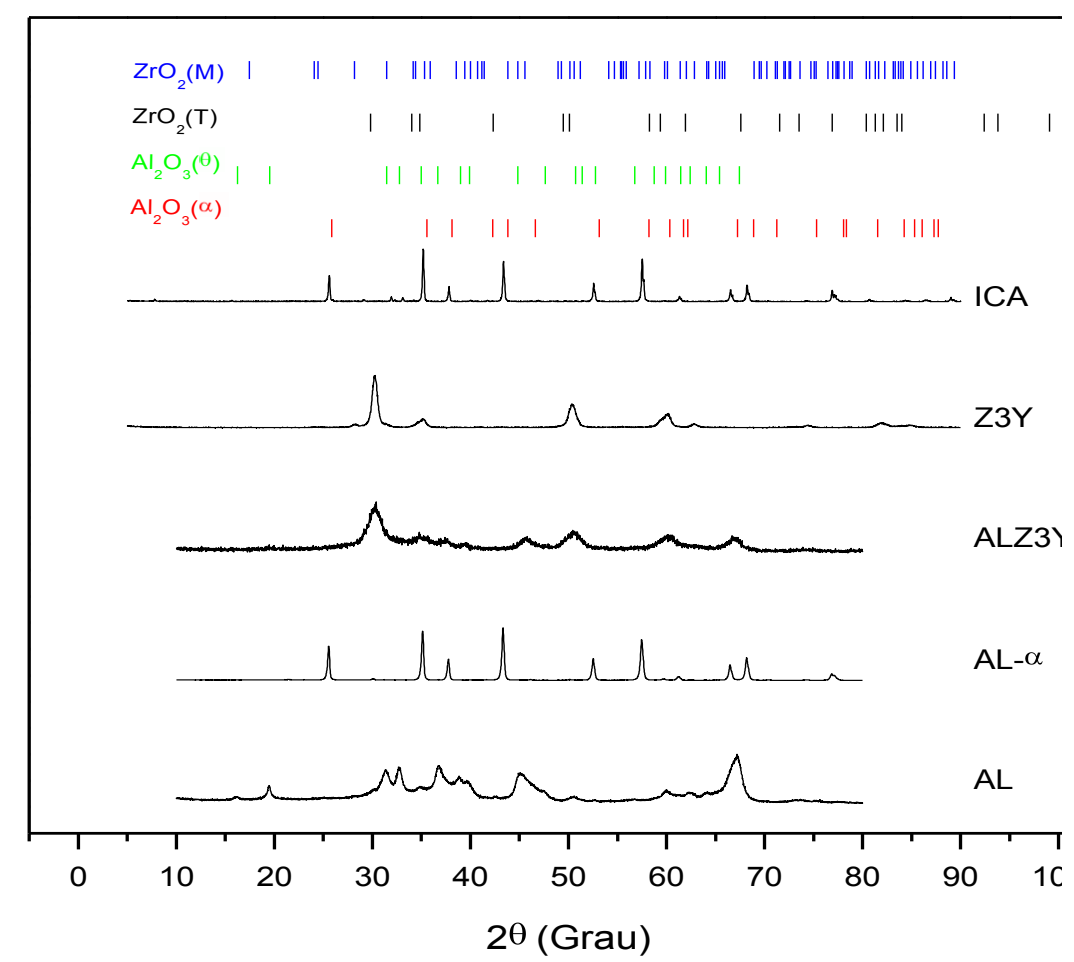

FIGURA 5.2.5. - Difratogramas de raios $X$ dos pós sintetizados à base de alumina $e$ zircônia e de procedência comercial (ICA). 


\subsection{Caracterização das cerâmicas sinterizadas}

Na FIG. 5.3.1., são apresentados os padrões de difração das amostras à base de alumina e zircônia, sinterizadas a $1200^{\circ} \mathrm{C}$ por 1 hora. A amostra de zircônia estabilizada apresenta reflexões características de fase tetragonal, a amostra $\mathrm{AL}$ das fases $\theta$ e $\alpha$ da alumina (estrutura monoclínica e romboédrica, respectivamente). Os dados referentes aos picos mais intensos, para as fases $\alpha$ e $\theta$ da alumina e tetragonal e monoclínica da zircônia, foram extraídos das fichas 11-0661, 35-0121, 42-1164 e 86-1451, respectivamente, do JCPDS-ICCD (Joint Committed Powder on Diffraction Standardt - The International Centre for Diffraction Data).

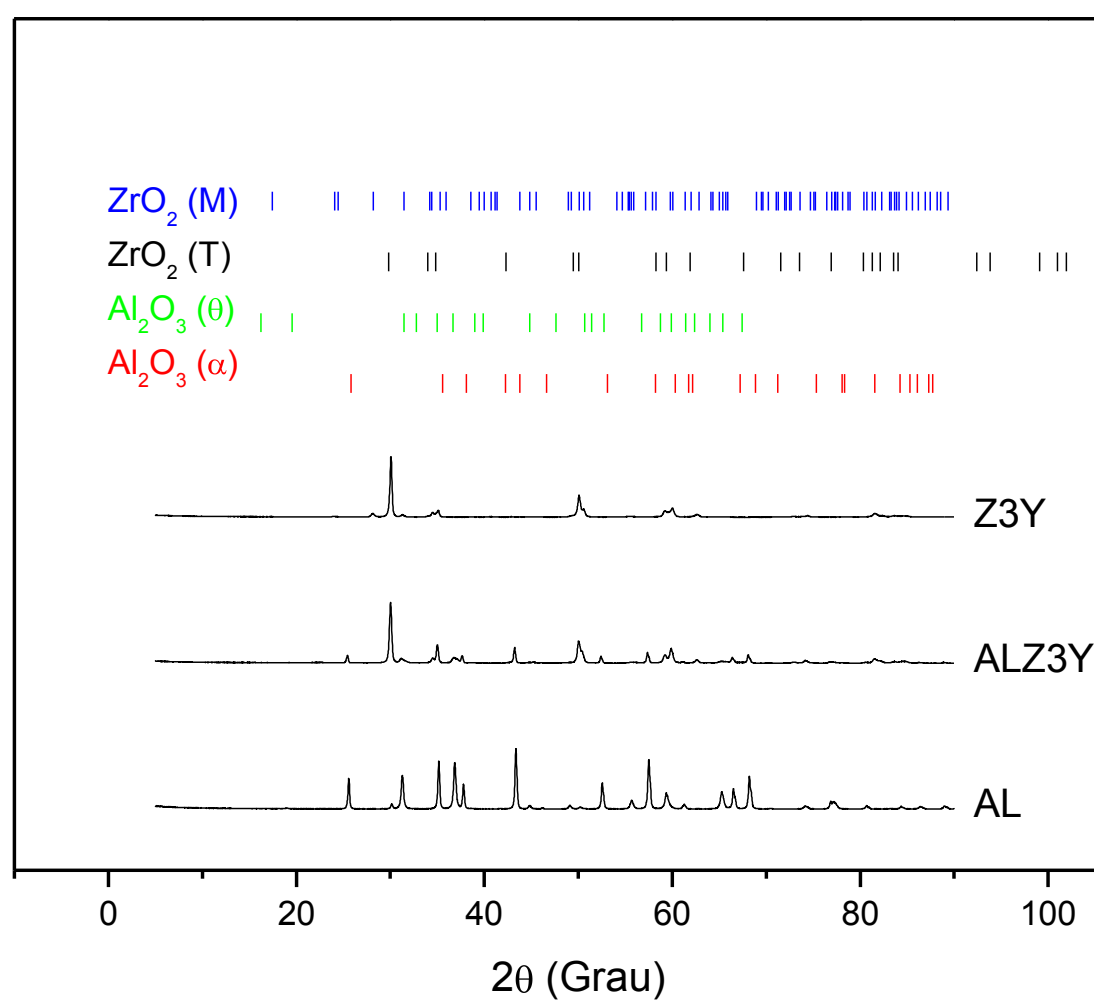

FIGURA 5.3.1. - Difratogramas de raios $X$ das cerâmicas à base de alumina e zircônia, sinterizadas a $1200^{\circ} \mathrm{C}$ por 1 hora. 
Na FIG. 5.3.2., são apresentadas as curvas de retração linear e de taxa de retração linear das cerâmicas estudadas.

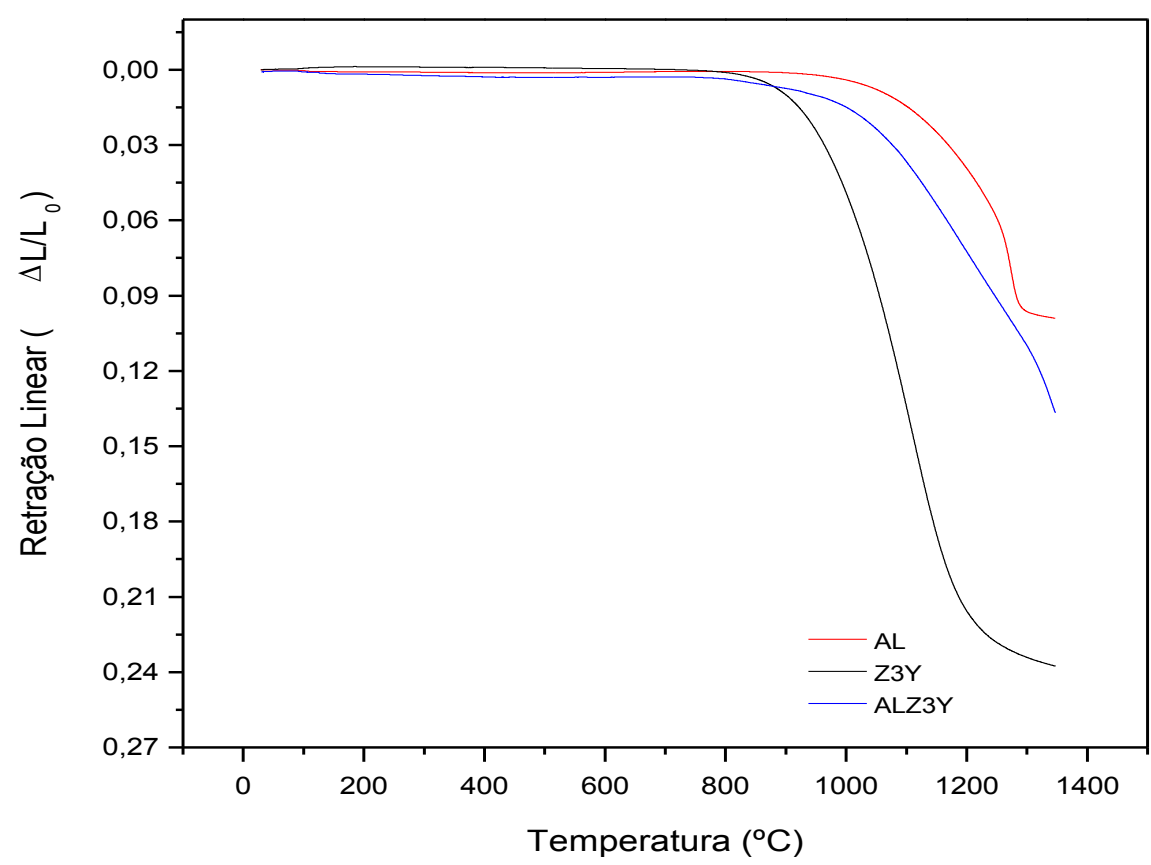

(a)

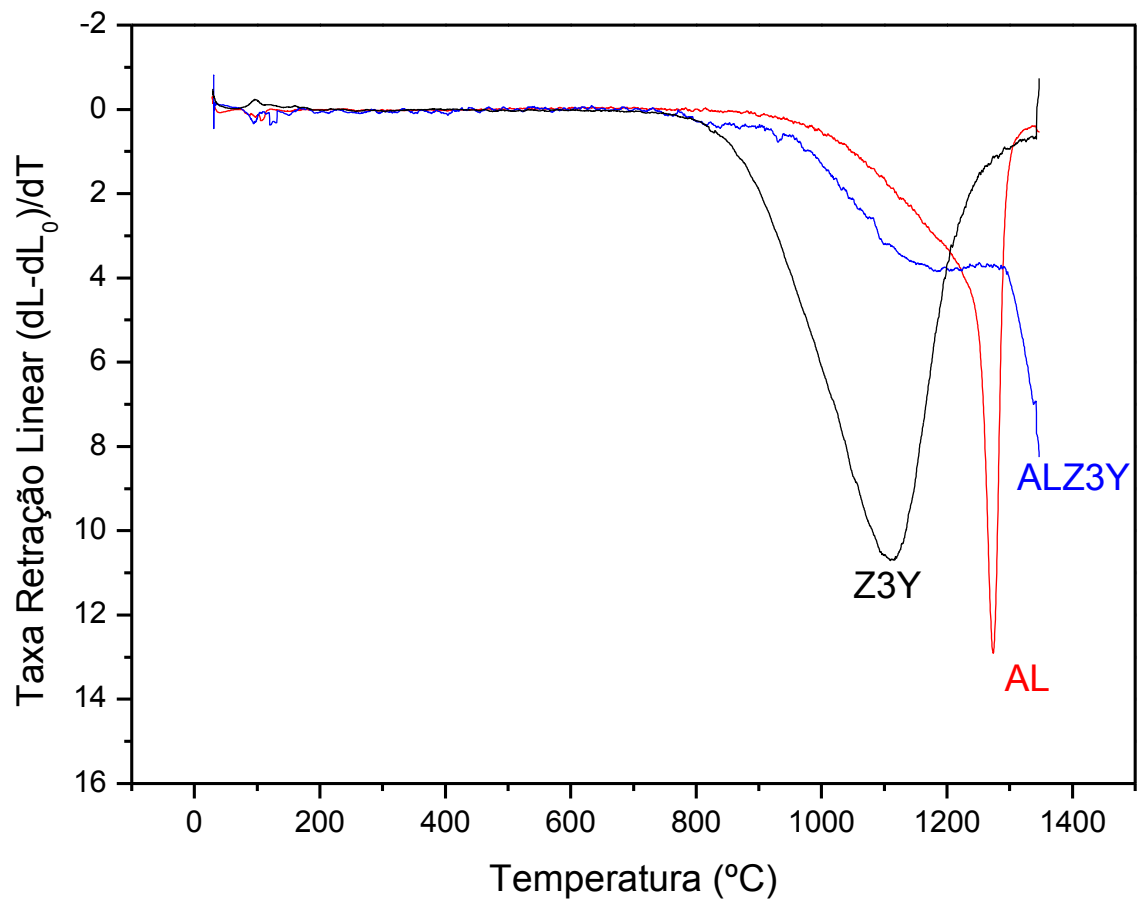

(b)

FIGURA 5.3.2. - Retração linear (a) e taxa de retração linear (b), em função da temperatura de sinterização das cerâmicas à base de alumina e zircônia. 
Verificou-se que a retração de todas as amostras inicia-se em torno de $850^{\circ} \mathrm{C}$. A temperatura de máxima retração da cerâmica $A L Z 3 Y$ não pode ser determinada uma vez que a temperatura de operação do equipamento utilizado é limitada a $1350^{\circ} \mathrm{C}$. Na TAB. 5.3.1. são apresentadas as temperaturas de máxima taxa de retração linear das amostras, valores este em torno de $1100^{\circ} \mathrm{C}$ para zircônia e $1300^{\circ} \mathrm{C}$ para alumina. As curvas de densidade relativa, obtidas a partir dos resultados das análises dilatométricas, são apresentadas na figura 5.3.3..

TABELA 5.3.1. - Temperatura de máxima taxa de retração linear das cerâmicas à base de alumina e zircônia.

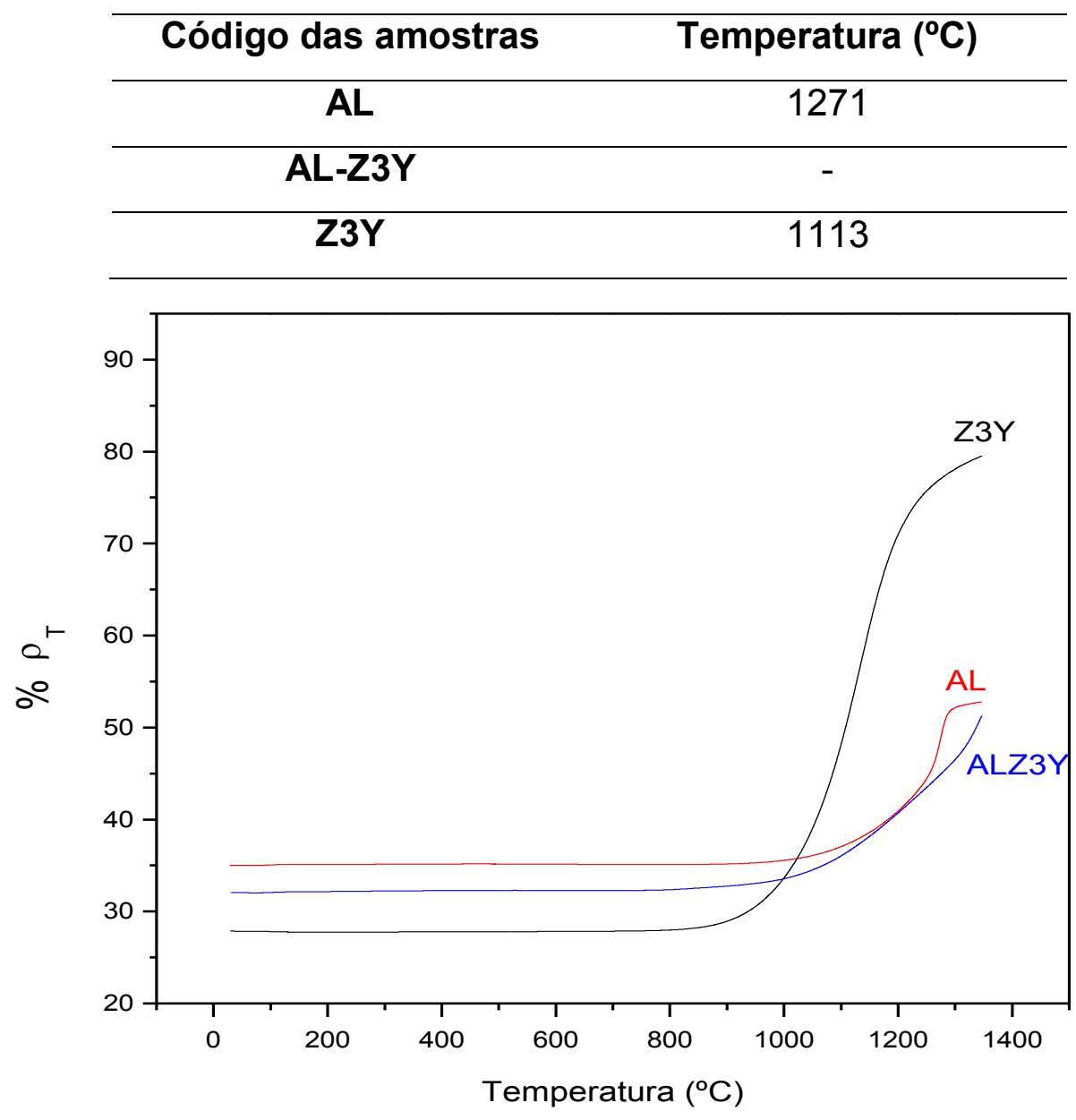

FIGURA 5.3.3. - Densidade relativa (\%DT), em função da temperatura de sinterização das cerâmicas à base de alumina e zircônia, determinada por dilatometria 
Na tabela 5.3.2 são apresentados os resultados de densidade aparente das amostras sinterizadas em diferentes condições de temperatura e tempo. De uma maneira geral, esses resultados indicam que a cerâmica de zircônia estabilizada apresenta melhor sinterabilidade em relação às cerâmicas contendo alumina.

TABELA 5.3.2 - Densidade aparente das cerâmicas em função das condições de sinterização

\begin{tabular}{|c|c|c|c|}
\hline \multirow{2}{*}{$\begin{array}{l}\text { Condição de } \\
\text { Sinterização }\end{array}$} & \multicolumn{3}{|c|}{ Densidade relativa $\left(\% \rho_{\mathrm{T}}-\mathrm{g} / \mathrm{cm}^{3}\right)$} \\
\hline & $A L$ & $A L-Z 3 Y$ & Z3Y \\
\hline $950^{\circ} \mathrm{C}-1 \mathrm{~h}$ & - & - & 48,7 \\
\hline $1000^{\circ} \mathrm{C}-1 \mathrm{~h}$ & - & - & 53,4 \\
\hline $1050^{\circ} \mathrm{C}-1 \mathrm{~h}$ & - & - & 71 \\
\hline $1100^{\circ} \mathrm{C}-1 \mathrm{~h}$ & 44 & 34,1 & 86,1 \\
\hline $1100^{\circ} \mathrm{C}-2 \mathrm{~h}$ & 47 & 33,4 & 88,3 \\
\hline $1150^{\circ} \mathrm{C}-1 \mathrm{~h}$ & - & - & 90,9 \\
\hline $1200^{\circ} \mathrm{C}-1 \mathrm{~h}$ & 51,2 & 39,5 & 91,1 \\
\hline $1200^{\circ} \mathrm{C}-2 \mathrm{~h}$ & 53,4 & 40,2 & 90,5 \\
\hline $1300^{\circ} \mathrm{C}-1 \mathrm{~h}$ & 50,8 & 43 & 92,9 \\
\hline $1300^{\circ} \mathrm{C}-2 \mathrm{~h}$ & 48,9 & 42,4 & 95 \\
\hline $1400^{\circ} \mathrm{C}-1 \mathrm{~h}$ & 55,7 & 45,1 & - \\
\hline $1500^{\circ} \mathrm{C}-1 \mathrm{~h}$ & 71,6 & 54,3 & 98,5 \\
\hline $1650^{\circ} \mathrm{C}-1 \mathrm{~h}$ & 77,7 & 86,5 & - \\
\hline
\end{tabular}

Valores de densidade teórica empregados:

Amostra $\mathrm{AL} \quad \Rightarrow \rho=3,98 \mathrm{~g} \cdot \mathrm{cm}^{-3}$

Amostra Z3Y $\Rightarrow \rho=6,10 \mathrm{~g} \cdot \mathrm{cm}^{-3}$

Amostra ALZ3Y $\Rightarrow \rho=4,44 \mathrm{~g} \cdot \mathrm{cm}^{-3}$ 
Micrografias de superfícies fraturadas, obtidas por microscopia eletrônica de varredura, apresentadas na FIG. 5.3.4., indicam que a microestrutura das amostras relativas à cerâmica de alumina e do compósito alumina-zircônia, sinterizadas à $1200^{\circ} \mathrm{C}$ por 1 hora, não é homogênea, uma vez que nesta condição o processo de sinterização ainda encontra-se no estágio inicial. Por sua vez, a cerâmica de zircônia estabilizada apresentou maior homogeneidade devido ao maior grau de densificação.
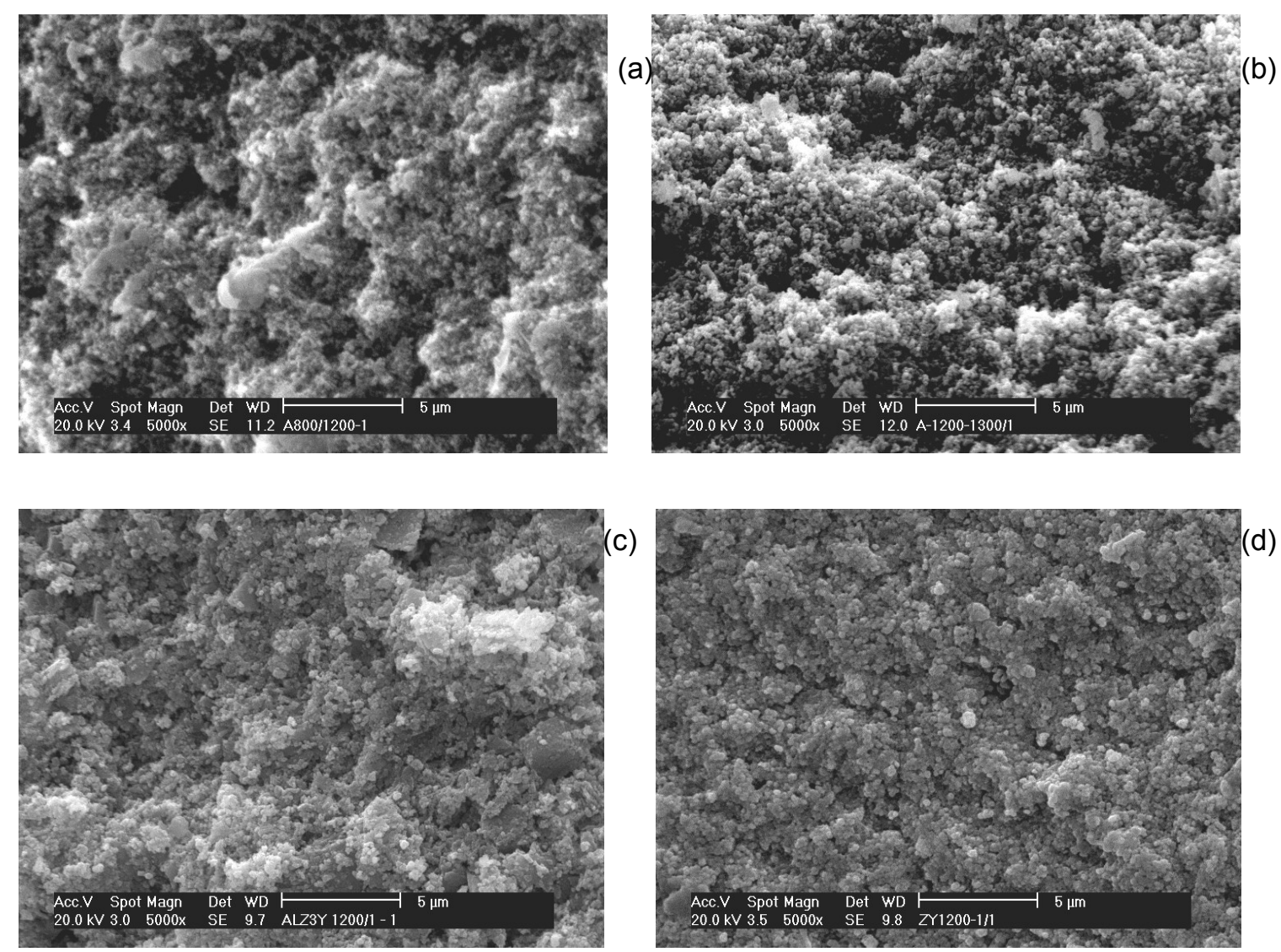

Figura 5.3.4 - Micrografias, obtidas por MEV, de superfícies fraturadas de cerâmicas de alumina, sinterizadas a 1200 e $1300^{\circ} \mathrm{C}$ por 1 hora: (a) AL-1200; (b) AL- $\alpha-1300$; (c) ALZ3Y-1200; e (d) hora: Z3Y1200.

Visando o controle da densificação dos corpos cerâmicos em $70 \%$ da densidade teórica do material, foi adicionado 10\% em massa de PVA (álcool poli 
vinilico), dissolvido em água, ao pó de zircônia estabilizada com ítria sob alta rotação (6000 RPM), seguido de secagem em estufa a $80^{\circ} \mathrm{C}$ por 24 horas e desagregação em almofariz de ágata. O pó de zircônia estabilizada com ítria também foi calcinado a $950^{\circ} \mathrm{C}$ por 1 hora, de forma tal que ocorra um decréscimo na reatividade deste pó, teoricamente, propiciando menor densificação ao corpo cerâmico em condições idênticas às anteriormente aplicadas. No caso das cerâmicas contendo alumina, em que foi observada menor densificação, quando comparada à cerâmica de zircônia, foi realizada moagem de alta energia por 15 horas nos pós sintetizados. Os resultados de densificação das amostras acima descritas são apresentados na TAB. 5.3.3 Nota-se que as cerâmicas de zircônia estabilizada apresentaram densidades próximas a $70 \%$ da densidade teórica do material quando sinterizadas a $1100^{\circ} \mathrm{C}$ por 1 hora, o que não aconteceu com a cerâmica de alumina. Conforme já relatado na literatura ${ }^{93}$, este comportamento provavelmente está correlacionado à presença de alumina $\theta$ nos pós sintetizados, a qual se transforma em alumina a durante o processo de sinterização. $\mathrm{Na}$ tentativa de inibir essa transformação, o pó do compósito contendo alumina foi calcinado a $1200^{\circ} \mathrm{C}$ por 1 hora. Utilizando a alumina comercial A1000SG (Alcoa), por mistura de pós, foram processados pós de alumina-zircônia estabilizada com $3 \mathrm{~mol} \%$ de ítria, sob alta rotação (6000 RPM), sendo em seguida seco em estufa a $80^{\circ} \mathrm{C}$ por 24 horas (TAB. 5.3.4.).

TABELA 5.3.3 - Densidade aparente das cerâmicas de zircônia estabilizada e alumina em função das condições de sinterização

\begin{tabular}{|c|c|c|c|}
\hline \multirow{2}{*}{$\begin{array}{c}\text { Código da } \\
\text { Amostra }\end{array}$} & \multicolumn{3}{|c|}{$\% \rho_{\mathrm{T}}\left(\mathrm{g} / \mathrm{cm}^{3}\right)$} \\
\hline & $1100^{\circ} \mathrm{C} / 1 \mathrm{~h}$ & $1200^{\circ} \mathrm{C} / 1 \mathrm{~h}$ & $1300^{\circ} \mathrm{C} / 2 \mathrm{~h}$ \\
\hline Z3Y-PVA & 68,9 & 72,7 & - \\
\hline Z3Y@950 & 67,5 & 81,8 & - \\
\hline AL-MAE & 35,5 & - & 46 \\
\hline $\begin{array}{ll}\text { Z3Y-PVA: } & \text { zirc } \\
\text { Z3Y@950: } & \text { zirc } \\
\text { AL-MAE } & \text { alun }\end{array}$ & $\begin{array}{l}\text { tabilizada com } \\
\text { tabilizada com } \\
\text { oída em moinh }\end{array}$ & $\begin{array}{l}101 \% \text { de ítria+ } \\
101 \% \text { de ítria, c } \\
\text { alta energia }\end{array}$ & $\begin{array}{l}\text { em massa de } \\
\text { nada a } 950^{\circ} \mathrm{C}\end{array}$ \\
\hline
\end{tabular}


TABELA 5.3.4. - Densidade aparente das cerâmicas de zircônia estabilizada e alumina.em função das condições de sinterização.

\begin{tabular}{cccccc}
\hline Código da & \multicolumn{5}{c}{$\% \rho_{\mathrm{T}}\left(\mathbf{g} / \mathbf{c m}^{3}\right)$} \\
\cline { 2 - 6 } Amostra & $1100^{\circ} \mathrm{C} / 1 \mathrm{~h}$ & $1100^{\circ} \mathrm{C} / 2 \mathrm{~h}$ & $1200^{\circ} \mathrm{C} / 1 \mathrm{~h}$ & $1200^{\circ} \mathrm{C} / 2 \mathrm{~h}$ & $1300^{\circ} \mathrm{C} / 1 \mathrm{~h}$ \\
\hline A1000SG-Z3Y & 48,9 & 47,6 & 49,7 & 51 & - \\
\hline AL-Z3Y@1200 & - & - & - & - & 35,9 \\
\hline
\end{tabular}

A1000SG-Z3Y: alumina comercial (A1000SG-Alcoa) + zircônia estabilizada com $\mathbf{3}$ mol\% de ítria AL-Z3Y@1200: compósito alumina-zircônia, proveniente de pó calcinado a $1200^{\circ} \mathrm{C}$

Com base nestes resultados comprovou-se a dificuldade de obtenção de cerâmicas porosas à base de alumina com densidade relativa em torno de $70 \%$. Apesar de este valor ser atingido a $1500^{\circ} \mathrm{C}$ por 1 hora, provavelmente a redução do tamanho e forma dos poros obtidos, devido à elevada temperatura de sinterização, dificultariam a infiltração da fase vítrea. Desta forma, foram selecionadas as seguintes condições de síntese e sinterização para preparação de cerâmicas infiltradas com fase vítrea de aluminoborossilicato de lantânio:

\section{cerâmica $\mathrm{AL}$}

- calcinação dos pós a $800^{\circ} \mathrm{C}$ por 1 hora; moagem em moinho de bolas por 16 horas

- sinterização a $1200^{\circ} \mathrm{C}$ por 2 horas

\section{cerâmica ALZ3Y}

- calcinação dos pós a $800^{\circ} \mathrm{C}$ por 1 hora; moagem em moinho de bolas por 16 horas

- sinterização a $1200^{\circ} \mathrm{C}$ por 2 horas

\section{cerâmica Z3Y}

- calcinação dos pós a $800^{\circ} \mathrm{C}$ por 1 hora; moagem em moinho de bolas por 16 horas

- sinterização a $1050^{\circ} \mathrm{C}$ por 1 hora 


\subsection{Síntese do vidro de aluminoborosilicato de lantânio e incorporação da fase vítrea de reforço}

Conforme já mencionado anteriormente, a síntese do vidro de aluminoborossilicato de lantânio foi realizada por mistura dos óxidos, em moinho de bolas por 5 horas, utilizando meios de moagem de alumina para propiciar melhor homogeinização da mistura. Após mistura, os óxidos precursores foram vertidos em cadinho de alumina e levados ao forno de elevação (Lindberg Blue), onde foram submetidos à tratamento térmico a $1250^{\circ} \mathrm{C}$ por 2 horas e então vertido em água para obtenção das fritas. Após moagem em moinho de bolas com meios de moagem de alumina a seco e desagregação em almofariz de ágata, foi realizada análise por microscopia eletrônica de varredura para verificação da forma e tamanho das partículas do pó de vidro (FIG. 5.4.1.).

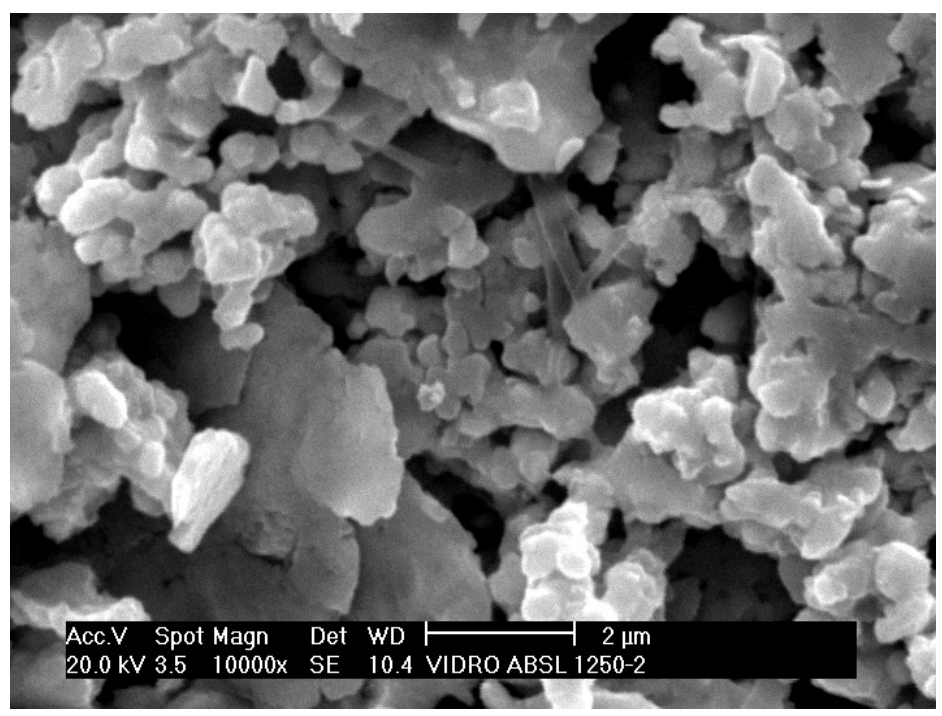

FIGURA 5.4.1. - Micrografia, obtida por MEV, do vidro de aluminoborosilicato de lantânio após moagem em moinho de bolas, por 5 horas, e desagregação em almofariz de ágata. 
A infiltração da fase vítrea e a sinterização do compósito vidro-cerâmica, foi realizada em forno do tipo caixa (Lindberg Blue), em temperaturas entre $1100 \mathrm{e}$ $1400^{\circ} \mathrm{C}$ variando-se o tempo entre 1 e 4 horas. Na tabela 5.4.1., são apresentadas as densidades relativas dos compósitos vidro-cerâmica sinterizados (V-AL, V-ALZ3Y e V-Z3Y) e das amostras infiltradas (AL(i), ALZ3Y(i) e Z3Y(i)).

Tabela 5.4.1. - Densidade aparente das cerâmicas contendo fase vítrea preparadas por infiltração ou mistura de pós.

$\% \rho_{\text {T }}\left(\mathbf{g} / \mathrm{cm}^{3}\right)$

Código da Amostra

Condição de impregnação da fase vítrea

$1200^{\circ} \mathrm{C} / 4 \mathrm{~h} \quad 1300^{\circ} \mathrm{C} / 2 \mathrm{~h} \quad 1400^{\circ} \mathrm{C} / 1 \mathrm{~h}$

\begin{tabular}{cccc}
\hline AL (i) & 65,9 & 82,9 & 99,7 \\
\hline AL(a) (i) & - & - & 83,3 \\
\hline ALZ3Y (i) & 59,5 & 86,4 & 95 \\
\hline Z3Y (i) & 98,1 & 97,4 & - \\
\hline V- AL (m) & 48,7 & 63,8 & 81,3 \\
\hline V-ALZ3Y (m) & 53,8 & 86,9 & 88,7 \\
\hline V-AL(a)Z3Y (m) & - & 70 & 79 \\
\hline V- Z3Y (m) & 76,1 & 78,9 & - \\
\hline
\end{tabular}

Cálculo baseado nos seguintes valores de densidade teórica:

$\rho_{\text {vidro }}=3,5 \mathrm{~g} \cdot \mathrm{cm}^{-3} ; \rho_{\mathrm{AL}}=3,98 \mathrm{~g} \cdot \mathrm{cm}^{-3} ; \rho_{\mathrm{AL}-Z 3 \mathrm{Y}}=4,44 ; \rho_{Z 3 \mathrm{Y}}=6,1 \mathrm{~g} \cdot \mathrm{cm}^{-3}$

Considerando-se a condição de integridade física das amostras e os resultados de densificação para testes de incorporação de fase vítrea (TAB. 5.4.2.), foram selecionadas as seguintes condições de processamento para incorporação da fase vítrea, sendo que o processo de infiltração deve ser realizado em duas ou três etapas para melhora da densificação da cerâmica: 
Por infiltração: $1200^{\circ} \mathrm{C}$ por 4 horas

Por mistura de pós: $1300^{\circ} \mathrm{C}$ por 2 horas

$\mathrm{Na}$ tentativa de proporcionar melhor infiltração da fase vítrea no corpo cerâmico foram realizadas infiltrações sucessivas (i, 2i e 3i) a uma mesma temperatura. Nas micrografias da FIG. 5.4.2, obtidas por MEV das superfícies de fratura, observa-se a redução de porosidade, melhor embricamento do vidro entre os grãos de zircônia e maior homogeneidade da microestrutura após a segunda infiltração a $1300^{\circ} \mathrm{C}$ por 2 horas.

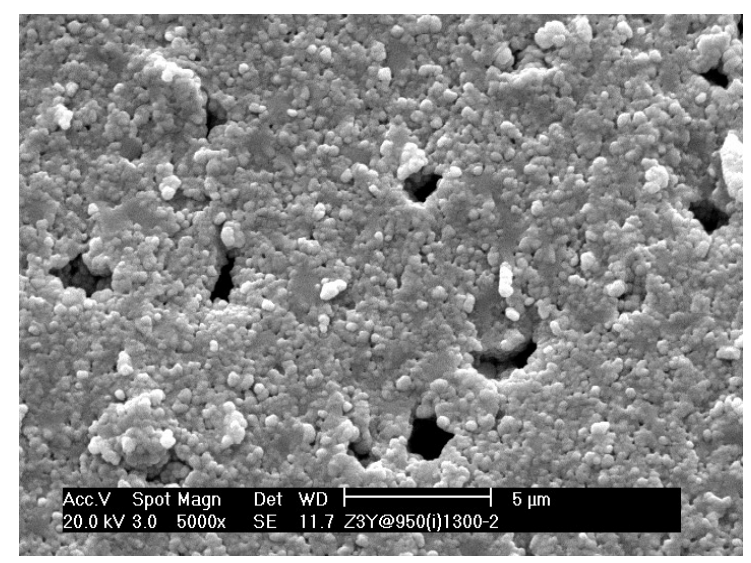

(a)

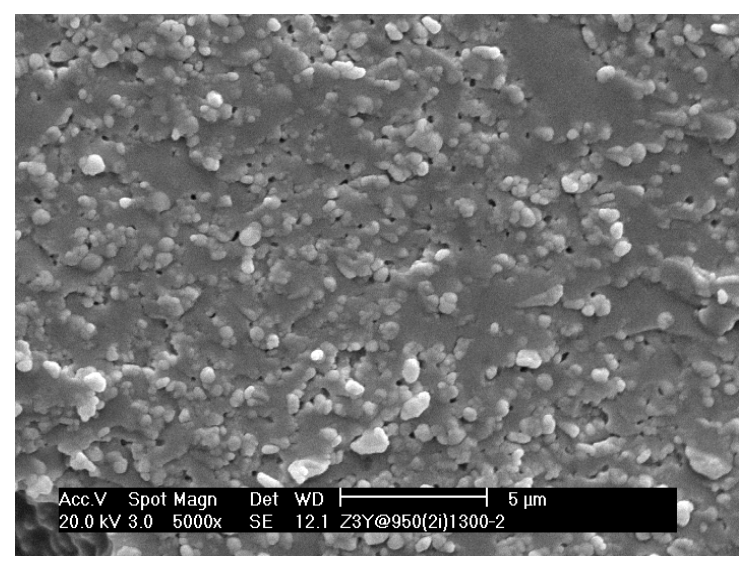

(b)

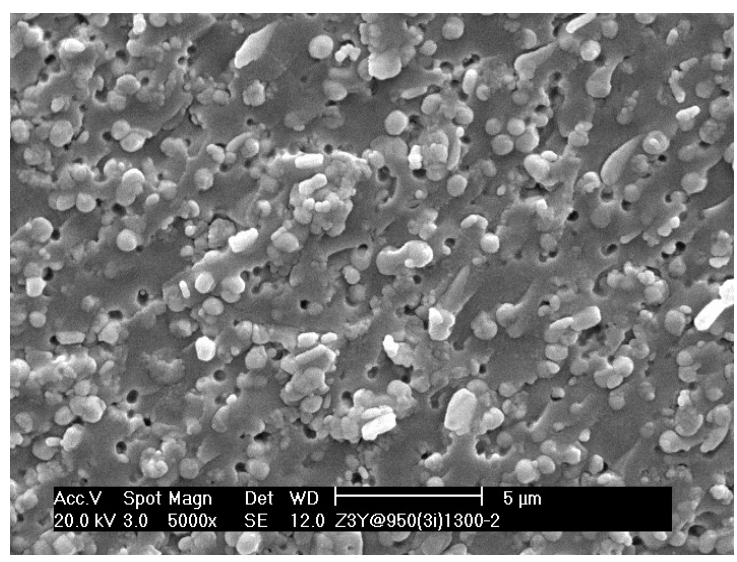

(c)

FIGURA 5.4.2 - Micrografias, obtidas por MEV, de cerâmicas de zircônia estabilizada com $3 \mathrm{~mol} \%$ de ítria, calcinadas a $950^{\circ} \mathrm{C}$, pré sinterizadas a $1100^{\circ} \mathrm{C}$ por 1 hora e infiltradas com vidro a $1300^{\circ} \mathrm{C}$ por 2 horas: (a) uma infiltração, (b) duas infiltrações e (c) três infiltrações. 
Amostras de uma cerâmica de alumina comercial (InCeram® Alumina), foram confeccionadas e submetidas a até três infiltrações consecutivas com vidro de aluminoborossilicato de lantânio do próprio sistema, apresentando porosidade condizente com a observada na FIG. 5.4.2. e valores de densidade para a amostra com uma infiltração (i) de 80,2\%, para duas infiltrações (2i) de 99,6\% e para três infiltrações (3i) de $90,4 \%$ da densidade teórica do material. Na FIG. 5.4.3., são apresentas fotografias de duas amostras infiltradas uma, duas e três vezes.
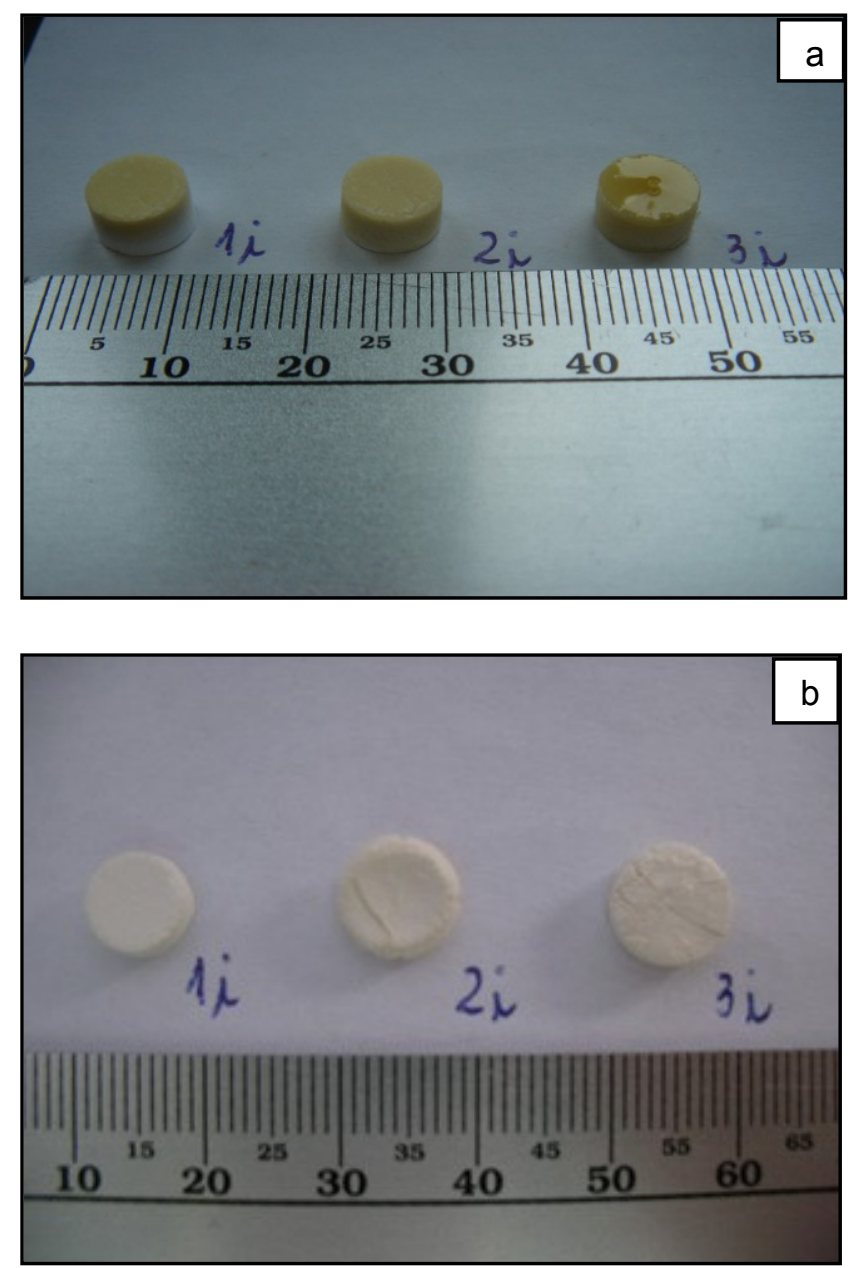

FIGURA 5.4.3. - Fotografias das amostras de alumina infiltrada a $1100^{\circ} \mathrm{C}$ por 4 horas (a) e zircônia estabilizada com $3 \mathrm{~mol} \%$ de ítria infiltrada a $1300^{\circ} \mathrm{C}$ por 2 horas (b), submetidas à três infiltrações com fase vítrea de aluminoborossilicato de lantânio. 
Conforme verificado na figura 5.4.3b, ocorreu a formação de macrotrincas nas amostras de zircônia estabilizada, fato este relacionado às diferenças existentes entre os coeficientes de expansão térmica dos materiais envolvidos ${ }^{98-}$ ${ }^{100}$, cujos valores são apresentados na tabela 5.4.2.

TABELA 5.4.2. - Coeficientes de expansão térmica dos materiais constituintes das cerâmicas odontológicas preparadas neste trabalho.

\begin{tabular}{ccc}
\hline Material constituinte & $\begin{array}{c}\text { Coeficiente de expansão térmica } \\
\text { CET }\left[\left({ }^{\circ} \mathrm{C}^{-1}\right)\right]\end{array}$ & Ref. \\
\hline Alumina & $7,8-8,1^{*} 10^{-6}$ & 99 \\
\hline $\begin{array}{c}\text { Zircônia estabilizada com 3 } \\
\text { mol\% de ítria }\end{array}$ & $11,85^{*} 10^{-6}$ & 100 \\
\hline $\begin{array}{c}\text { Compósito alumina-20\% em } \\
\text { massa de zircônia }\end{array}$ & $9,86^{*} 10^{-6}$ & 100 \\
\hline $\begin{array}{c}\text { Compósito zircônia-20\% em } \\
\text { massa de alumina }\end{array}$ & $11,26^{*} 10^{-6}$ & 100 \\
\hline $\begin{array}{c}\text { Vidro alumínio borossilicato de } \\
\text { lantânio }\end{array}$ & $9,16^{*} 10^{-6}$ & 100 \\
\hline
\end{tabular}

Segundo relatos da literatura ${ }^{100}$, é importante que o coeficiente de expansão térmica do vidro escolhido seja relativamente inferior ao da cerâmica de infraestrutura. Outro parâmetro relevante para avaliação da eficiência de infiltração é a molhabilidade do vidro na superfície do substrato. Neste caso, o parâmetro geralmente avaliado é o ângulo de contato $(\theta)$, o qual representa o balanço das energias interfaciais entre a fase sólida e a fase líquida. Quando $\theta$ $=0^{\circ}$, o molhamento é máximo sobre a superfície do sólido, $\theta=90^{\circ}$ o molhamento é parcial e para $\theta=180^{\circ}$ não ocorre molhamento. $O$ estudo de molhabilidade de cerâmicas geralmente é realizado pelo método de "gota séssil", o qual consiste na avaliação do ângulo de contato vidro/substrato cerâmico pela fusão do vidro sobre 
a superfície do substrato polido, em função do tempo e temperatura de aquecimento. O ponto de fusão do vidro é determinado quando este apresenta formato de meia esfera, sendo no caso do vidro de borossilicato de lantânio $1264^{\circ} \mathrm{C}$. Segundo dados publicados por Bighetti et al. ${ }^{100}$, a taxa de espalhamento sobre os substratos $80 \%$ em massa de zircônia - $20 \%$ de alumina (Z8A2) e $20 \%$ em massa de zircônia - 80\% em massa de alumina (Z2A8) são semelhantes, com ângulo de contato de $13,64^{\circ}$ e $12,71^{\circ}$, a 1285 e $1275^{\circ} \mathrm{C}$, respectivamente, valores estes que indicam a boa molhabilidade das cerâmicas em questão. Considerando-se também as menores diferenças de coeficiente de expansão térmica com o vidro de aluminoborossilicato de lantânio, o substrato contendo maior fração de alumina é o mais indicado para infiltração da fase vítrea.

Uma análise comparativa entre as amostras cuja incorporação da fase vítrea foi realizada pela técnica de infiltração e por mistura de pós indica que em ambos os casos, a presença de porosidade residual é um problema de processamento a ser resolvido. No entanto, observa-se nas imagens apresentadas na figura. 5.4.4. que a dimensão dos poros decorrentes do processamento por mistura de pós é superior a $100 \mu \mathrm{m}$. Neste caso, a temperatura de sinterização é um parâmetro que deve ser estudado para melhorar a molhabilidade da fase vítrea nos grãos de fase cristalina. 


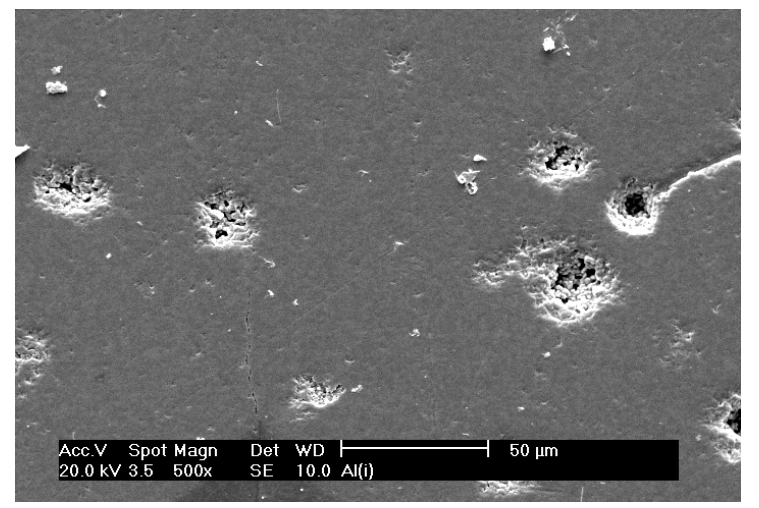

(a)

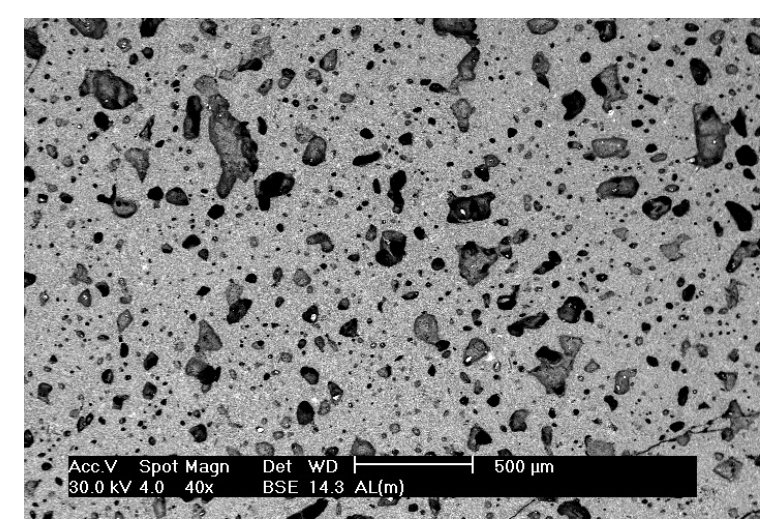

(c)

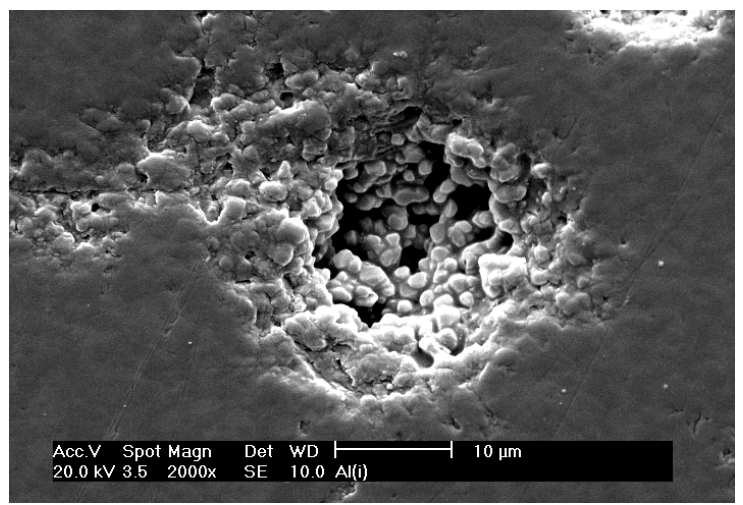

(b)

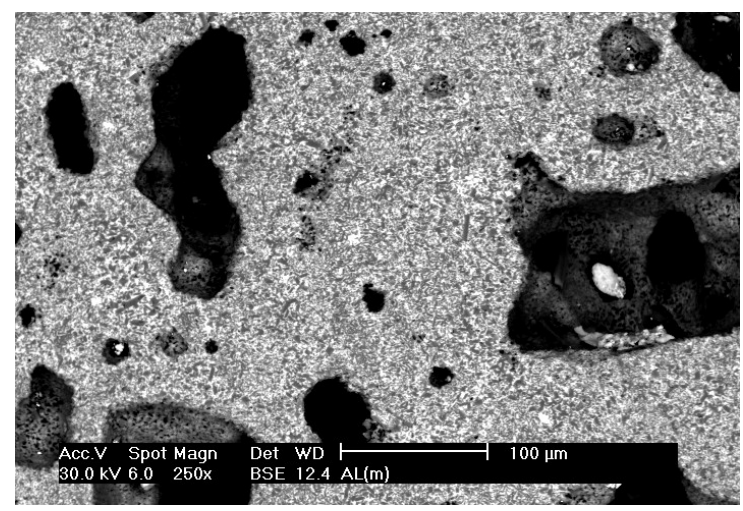

(d)

Figura 5.4.4 - Micrografias, obtidas por MEV, das cerâmicas de alumina contendo fase vítrea de alumínioborossilicato de lantânio, mostrando a formação de porosidade durante o processamento: $(a-b)$ amostra $A L(i)$ e (c-d) amostra $A L(m)$.

As micrografias, obtidas por MEV, e espectros semi-quantitativos de EDS das fases constituintes das cerâmicas de alumina, zircônia estabilizada com $3 \mathrm{~mol} \%$ de ítria e do compósito alumina-zircônia, infiltradas com vidro de aluminoborosilicato de lantânio, são apresentadas nas FIG. 5.4.5, 5.4.6 e 5.4.7. Para as amostras contendo alumina, nota-se uma excelente distribuição da fase vítrea, que contém maior concentração dos elementos alumínio, silício e lantânio (regiões 2 e 3 das FIG. 5.4 .5 e 5.4.7, respectivamente), entre os grãos de fase cristalina. 


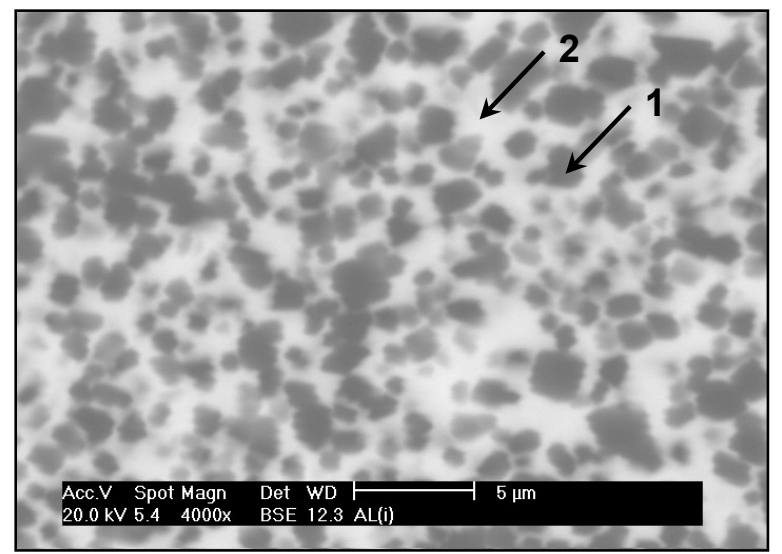

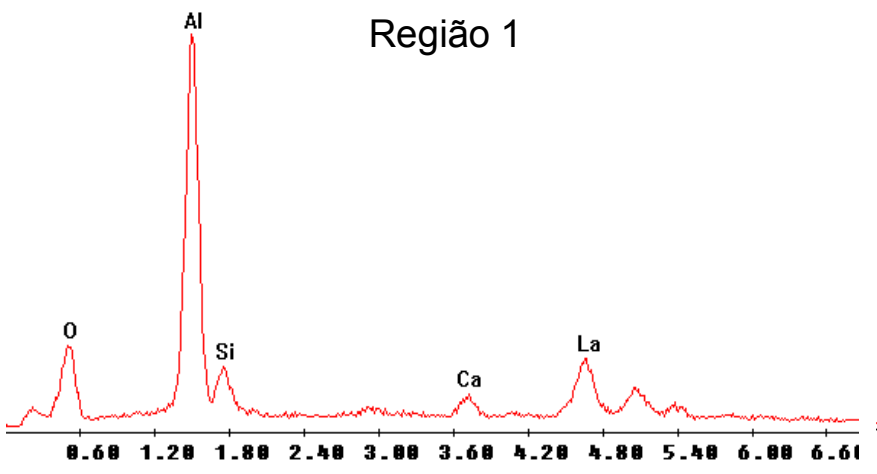

Energia (eV)

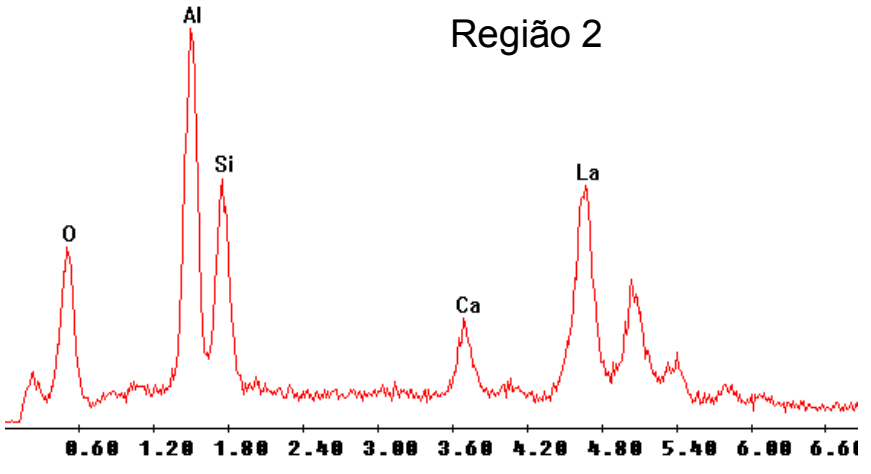

Energia (eV)

FIGURA 5.4.5 - Micrografia, obtida por MEV, e EDS da cerâmica de alumina infiltrada com fase vítrea de alumínioborossilicato de lantânio (amostra $\mathrm{AL}(\mathrm{i}))$.

Os resultados da FIG. 5.4.6, relativos à amostra de zircônia estabilizada, constataram a dificuldade de infiltração vítrea nesta cerâmica, provavelmente devido à maior sinterabilidade deste material na etapa de formação da infraestrutura porosa, diminuindo a concentração de poros abertos. Além deste fato, o processo de sinterização deve ter tido continuidade durante a etapa de tratamento térmico de incorporação do vidro. 

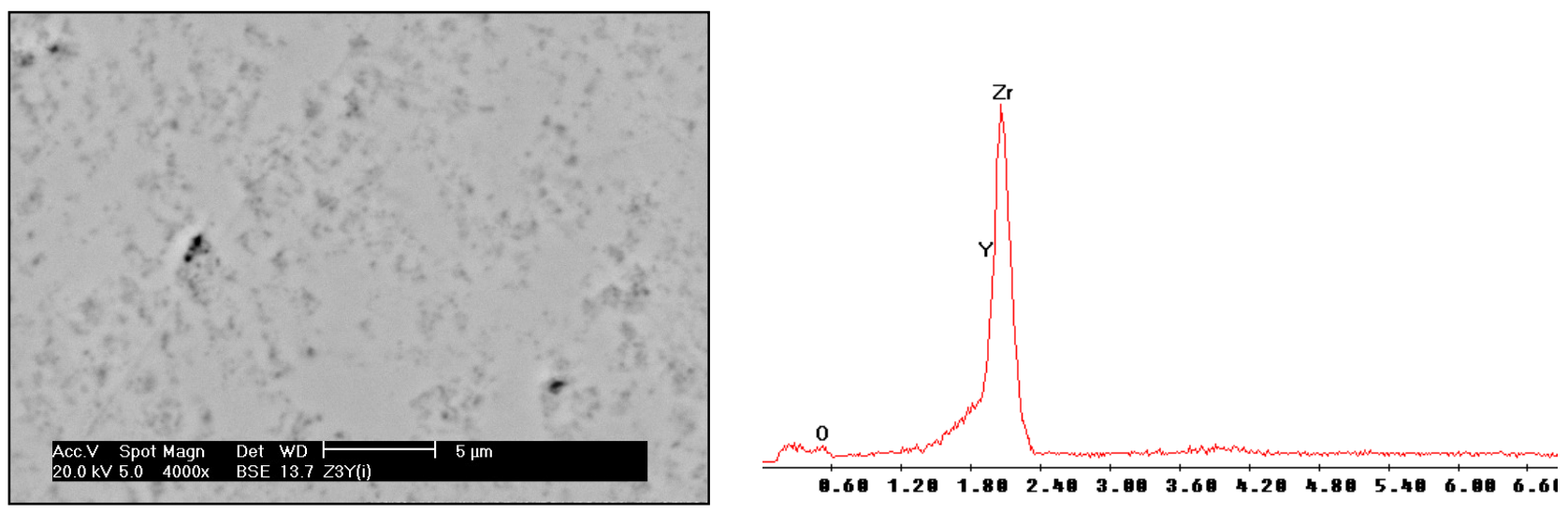

Energia (eV)

FIGURA 5.4.6. - Micrografia, obtida por MEV, e EDS da cerâmica de zircônia estabilizada infiltrada com fase vítrea de alumínioborossilicato de lantânio (amostra Z3Y (i)) 

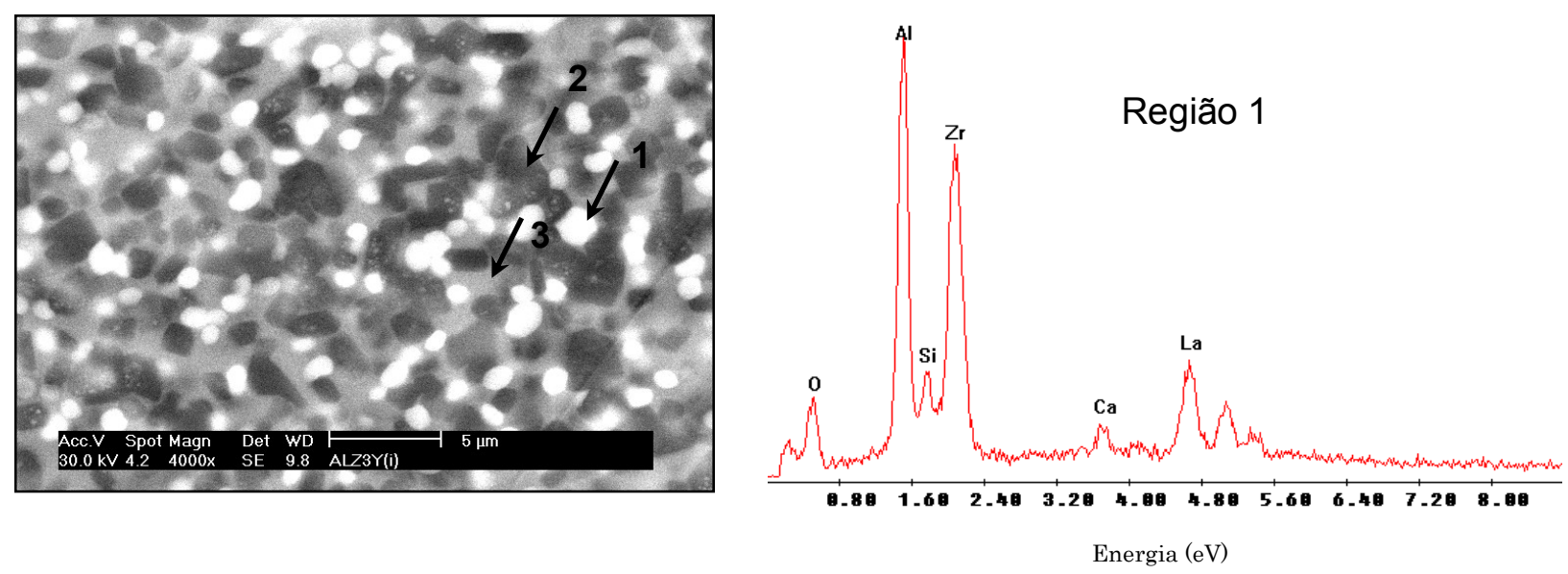

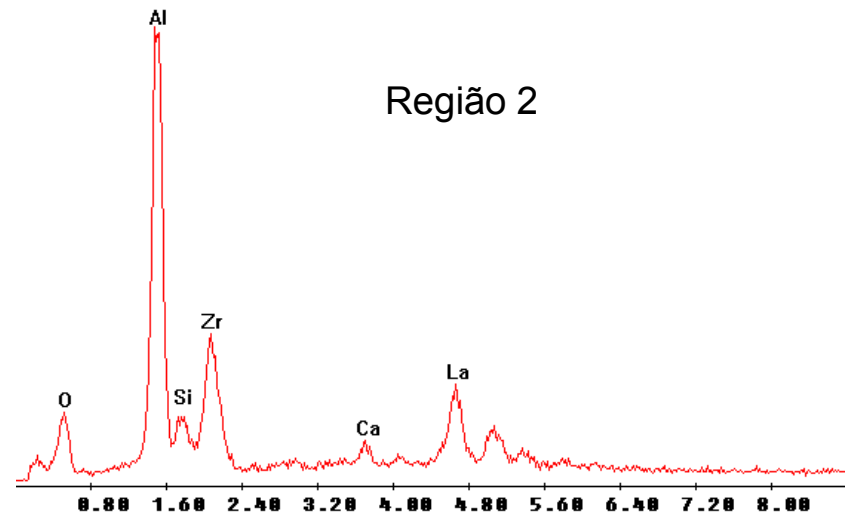

Energia (eV)

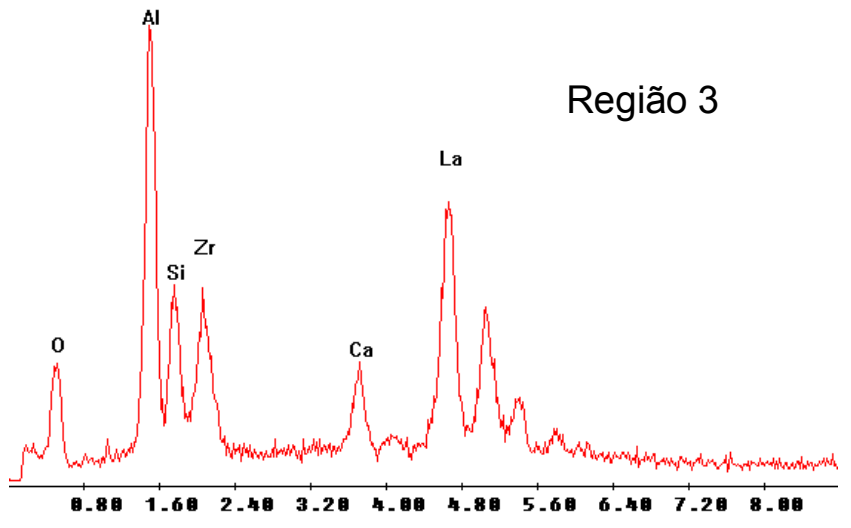

Energia (eV)

FIGURA 5.4.7 - Micrografia, obtida por MEV, e EDS do compósito de aluminazircônia infiltrada com fase vítrea de alumínioborossilicato de lantânio (amostra ALZ3Y (i)).

As micrografias e espectros de EDS, das FIG. 5.4.8, 5.4.9 e 5.4.10, são relativos às cerâmicas de alumina, zircônia estabilizada com $3 \mathrm{~mol} \%$ de ítria e do compósito alumina-zircônia com incorporação de fase vítrea por mistura de pós. Também neste caso foi observada boa homogeneidade de distribuição das fases. Os grãos de alumina apresentam-se mais alongados característicos da alumina alfa, enquanto os grãos de zircônia são mais arredondados e de menor tamanho $(<1 \mu \mathrm{m})$. A presença de silício e lantânio, no espectro de EDS da FIG. 5.4.9, 
indica a presença de fase vítrea na cerâmica de zircônia, que não pode ser notada quando se utilizou o processo de infiltração.

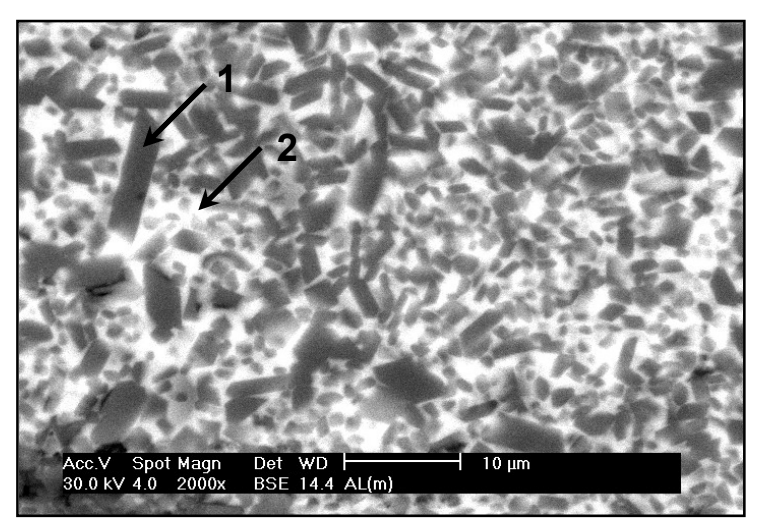

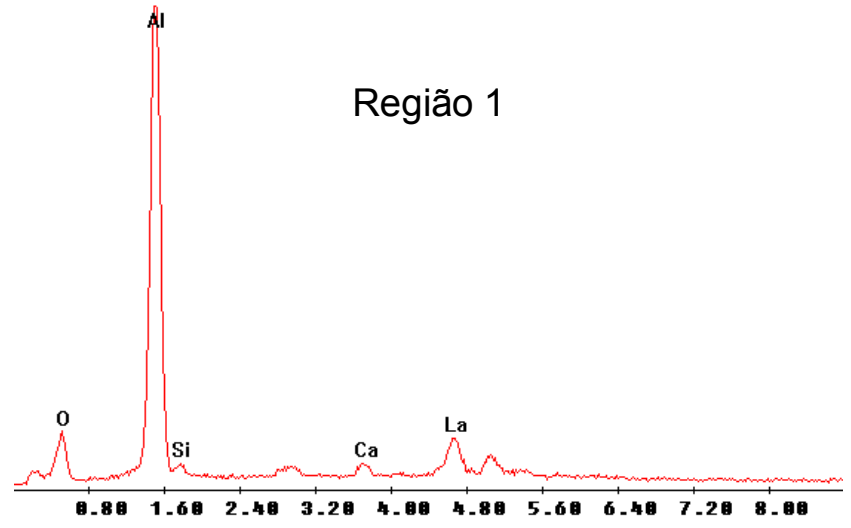

Energia (eV)

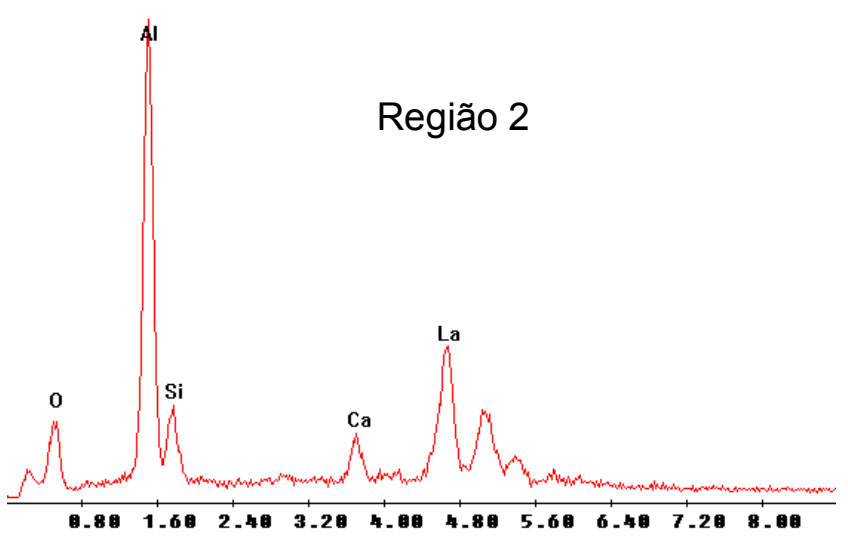

Energia (eV)

FIGURA 5.4.8 - Micrografia, obtida por MEV, e EDS da cerâmica de alumina impregnada com fase vítrea de alumínioborossilicato de lantânio, por mistura de pós (amostra $\mathrm{AL}(\mathrm{m})$ ). 

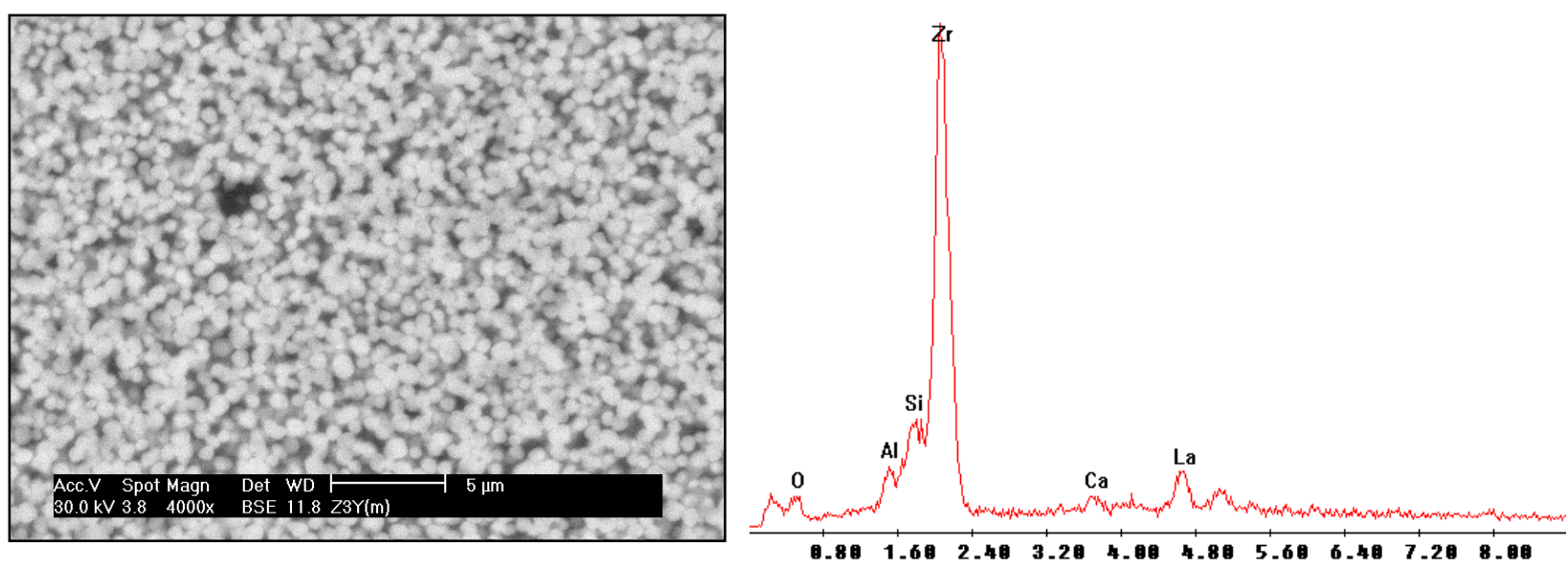

Energia (eV)

FIGURA 5.4.9 - Micrografia, obtida por MEV, e EDS da cerâmica de zircônia estabilizada impregnada com fase vítrea de alumínioborossilicato de lantânio, por mistura de pós (amostra Z3Y $(m))$ 

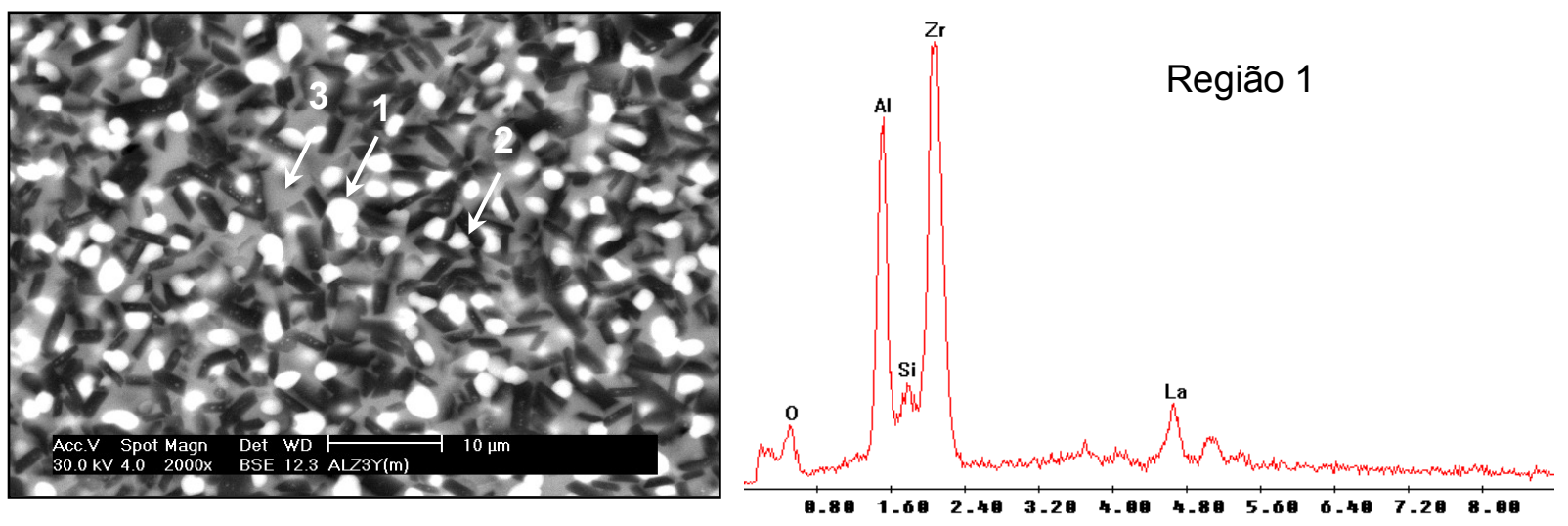

Energia $(\mathrm{eV})$

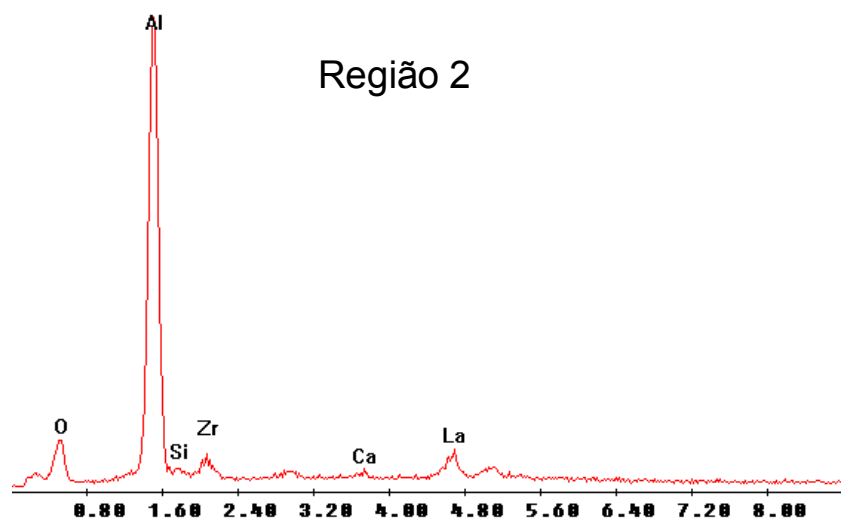

Energia $(\mathrm{eV})$

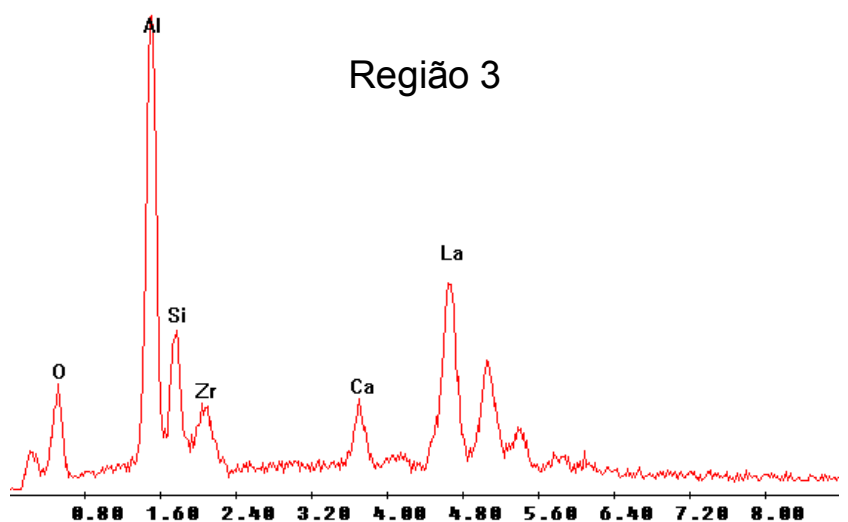

Energia (eV)

FIGURA 5.4.10 - Micrografia, obtida por MEV, e EDS do compósito de zircôniaalumina impregnado com fase vítrea de alumínioborossilicato de lantânio, por mistura de pós (amostra ALZ3Y (m))

Os difratogramas de raios $X$ da FIG. 5.4.11 indicam a presença de alumina $\alpha$ nas amostras $A L(i)$ e $A L(m)$, zircônia tetragonal na amostra Z3Y(i) e mistura de fases tetragonal e monoclínica na Z3Y (m). Finalmente, nas cerâmicas ALZ3Y(i) e $\operatorname{ALZ3Y}(\mathrm{m})$ observou-se a presença das fases $\alpha$ da alumina e tetragonal $e$ monoclínica da zircônia, sendo a formação desta última consequência da 
acomodação das tensões térmicas geradas na etapa de incorporação da fase vítrea.
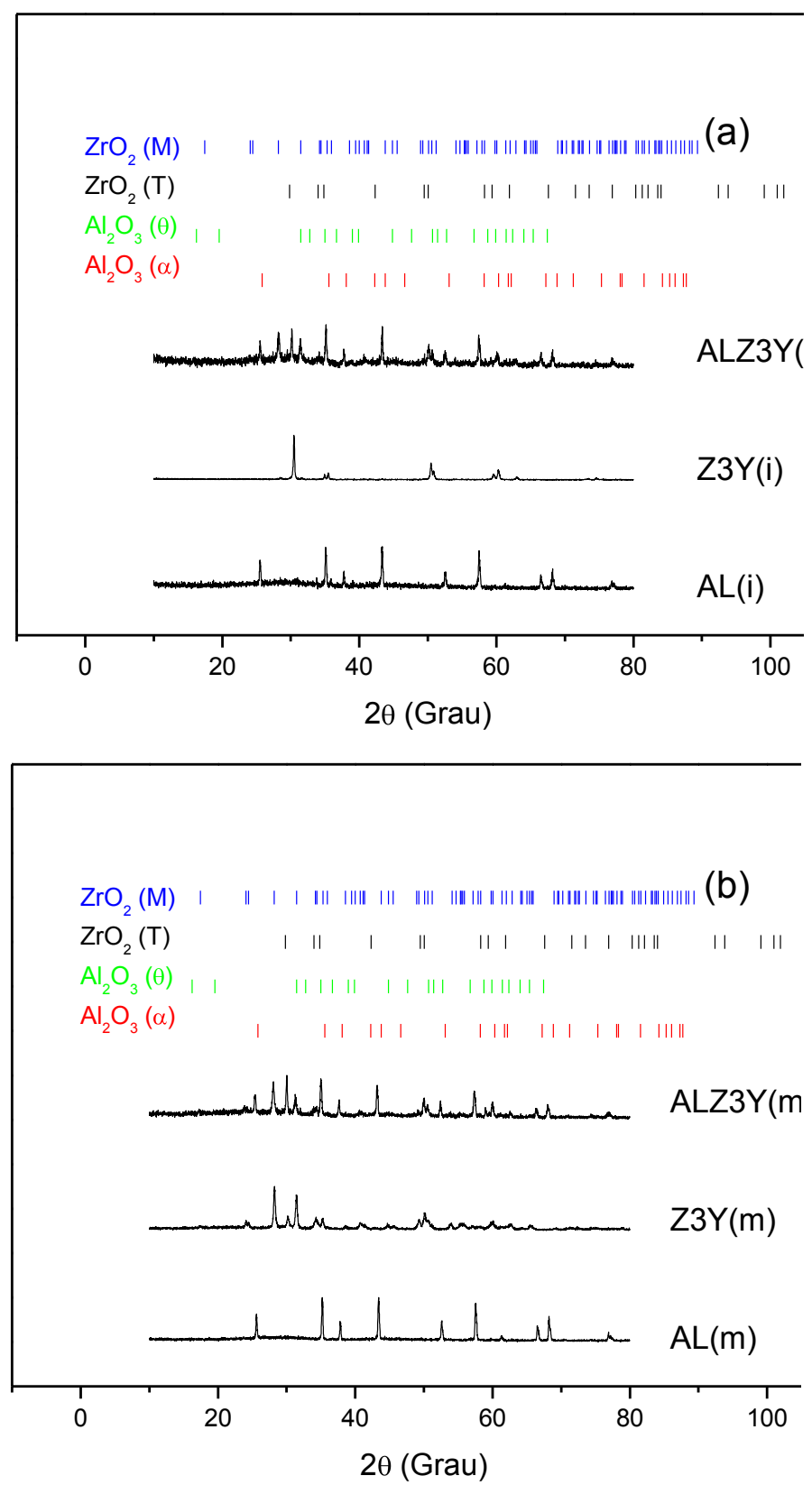

Figura 5.4.11 - Difratogramas de raios $X$ das cerâmicas à base de alumina e zircônia após incorporação da fase vítrea (a) por impregnação e (b) por mistura de pós.

Nas micrografias da FIG 5.4.12, obtidas por MO, são apresentadas imagens de impressão Vickers, após o ensaio de dureza, das cerâmicas de alumina (carga de 49,03 N), compósito alumina-zircônia (carga de 98,07 N) e zircônia estabilizada com 3mol\% de ítria (carga de 98,07 N), infiltradas por vidro 
de alumínioborosilicato de lantânio. Após breve polimento ( $1 \mathrm{~min})$, com suspensão de diamante de granulometria $1 \mu \mathrm{m}$, foi possível observar que as trincas apresentam redução de tamanho, mas não se separam dos vértices, indicando a formação de trincas do tipo radial-mediana. As regiões mais escuras são relativas aos poros residuais.
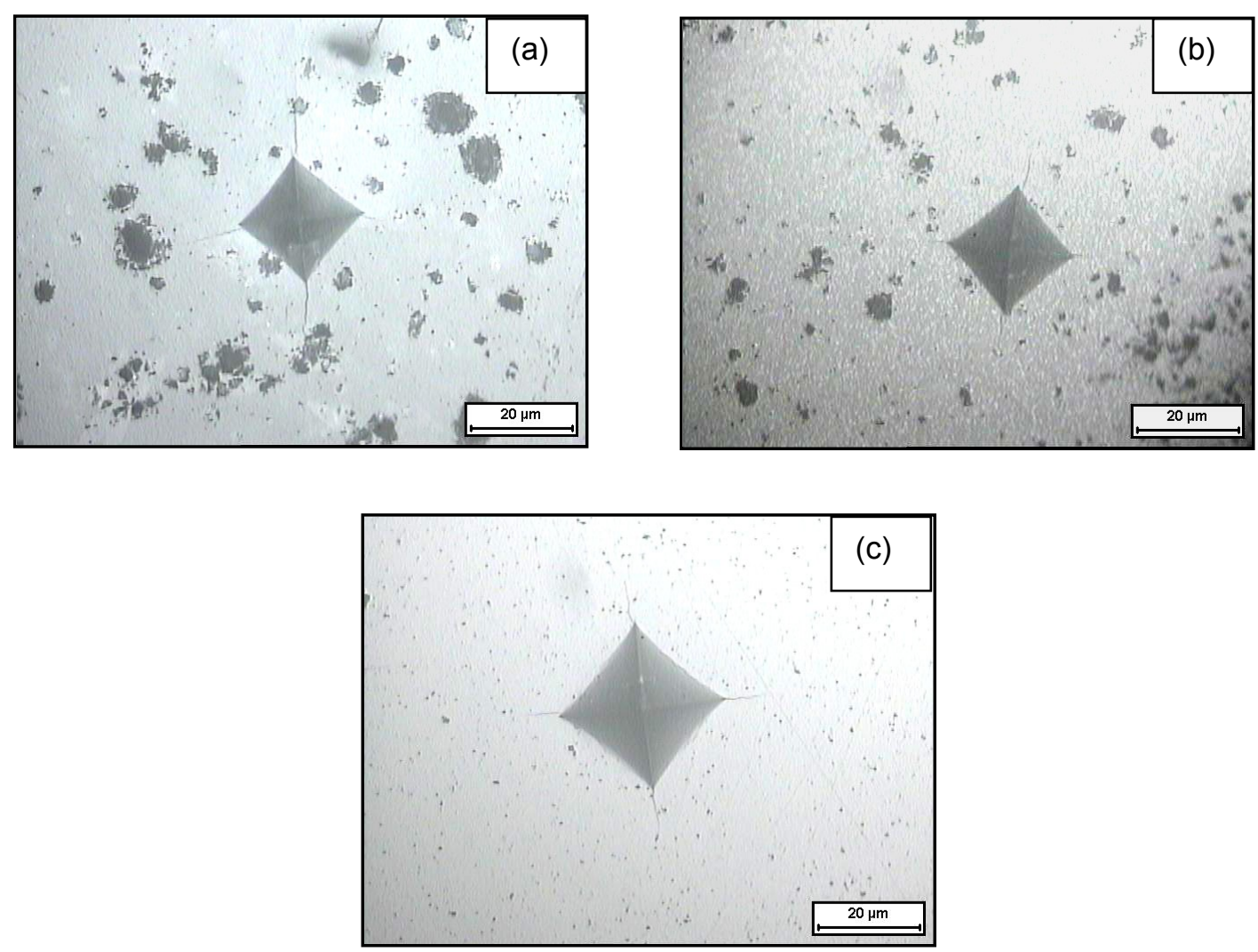

FIGURA 5.4.12 - Micrografias, obtidas por microscopia ótica, de impressão Vickers em cerâmicas de alumina (a), alumina-zircônia (b) e zircônia estabilizada com 3 mol\% de ítria (c), submetidas à infiltração com fase vítrea de alumino borossilicato de lantânio.

Imagens das impressões Vickers e das trincas geradas nas cerâmicas de alumina, compósito alumina-zircônia e zircônia estabilizada também são apresentadas nas micrografias obtidas por MEV da FIG. 5.4.13. Nota-se a grande extensão e espessura das trincas das amostras contendo alumina, diferenciandose das amostras de zircônia, onde atuam os mecanismos de reforço por transformação de fase tetragonal $\rightarrow$ monoclínica. 


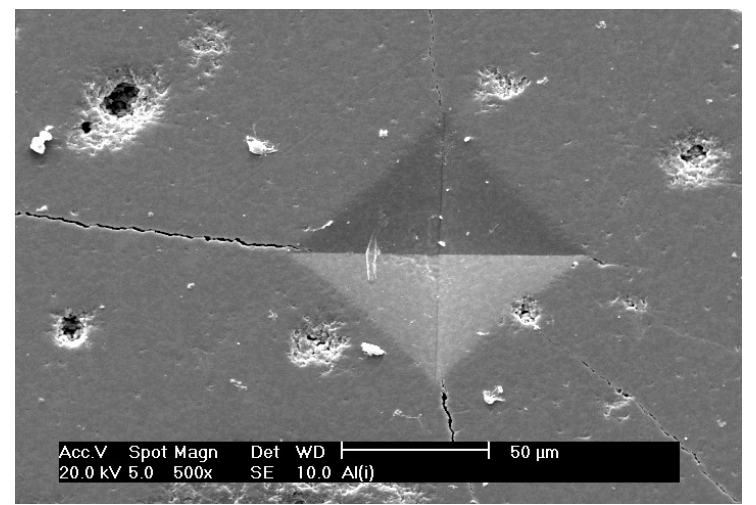

(a)

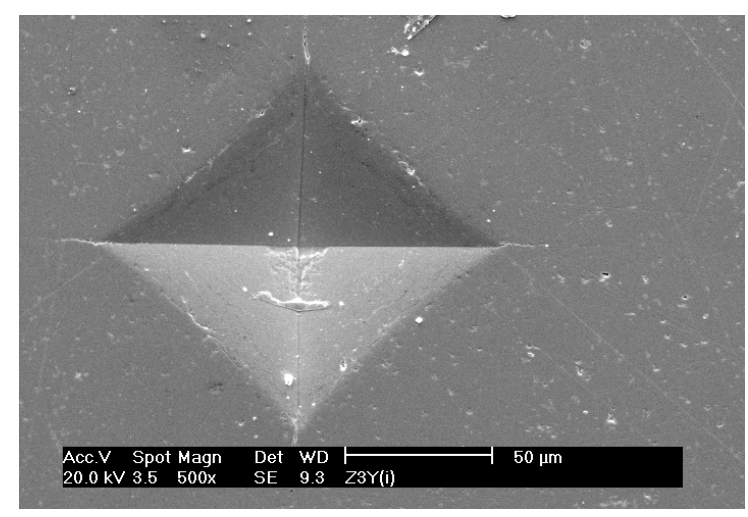

(c)

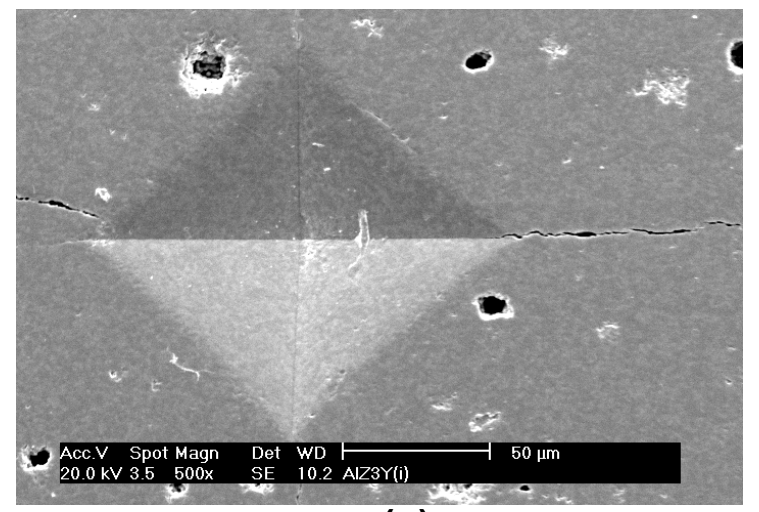

(e)

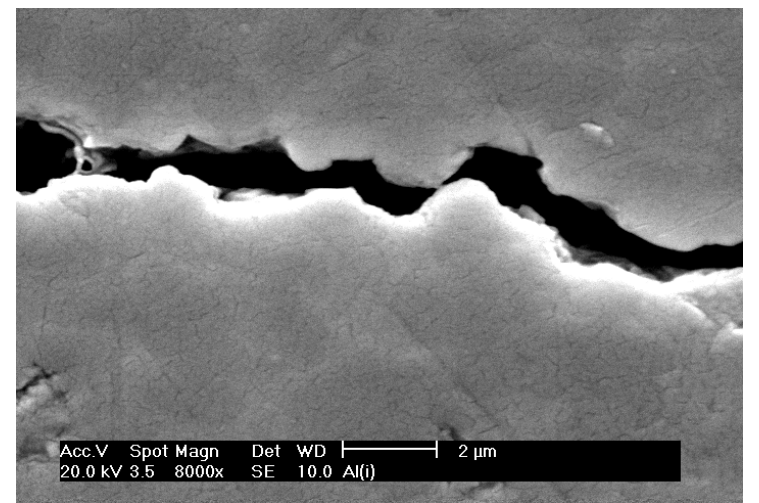

(b)

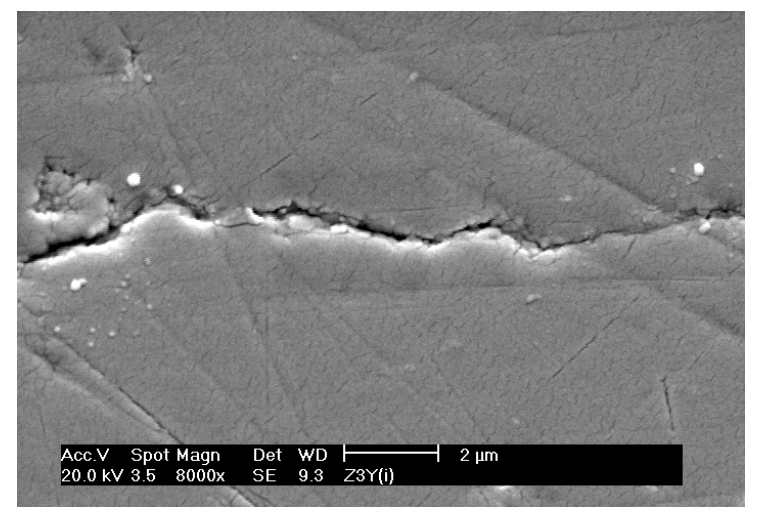

(d)

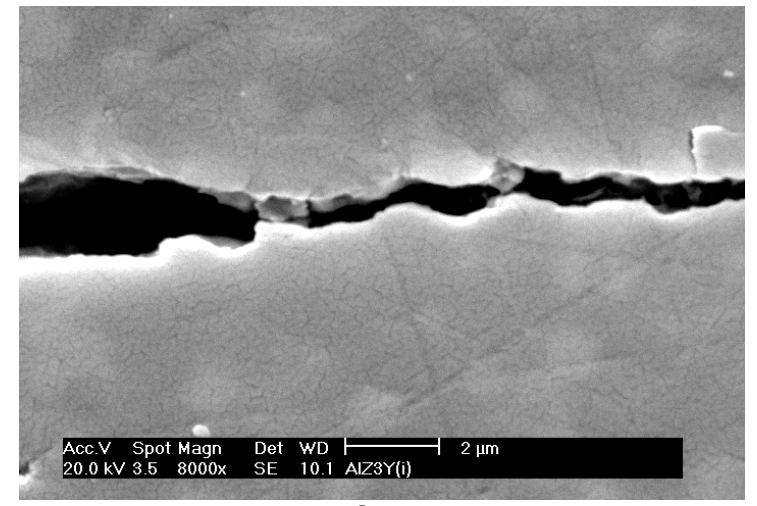

(f)

FIGURA 5.4.13 - Micrografias, obtidas por microscopia eletrônica de varredura, mostrando detalhes das indentações e trincas formadas nas cerâmicas infiltradas com fase vítrea, após ensaios de impressão Vickers: $(\mathrm{a}-\mathrm{b})$ amostra $\mathrm{AL}$ i; $(\mathrm{c}-\mathrm{d})$ amostra Z3Y i; (e - f) amostra ALZ3Y i. 
$\mathrm{Na}$ TAB. 5.4.3, são apresentados os resultados de dureza e tenacidade à fratura das amostras sintetizadas no presente trabalho e, para efeito de comparação, os valores apresentados em trabalhos publicados na literatura. As amostras produzidas por mistura de pós não foram avaliadas quanto à tenacidade, pois o teste ficou comprometido devido à elevada concentração de poros.

Tabela 5.4.3. - Valores de dureza e tenacidade à fratura das cerâmicas à base de alumina e zircônia contendo fase vítrea de aluminoborossilicato de lantânio, de procedência comercial e preparadas neste trabalho.

\begin{tabular}{|c|c|c|c|c|}
\hline Codificação & $\begin{array}{c}\text { Técnica de } \\
\text { conformação da } \\
\text { matriz cerâmica } \\
\text { porosa } \\
\end{array}$ & Hv (GPa) & $\mathrm{K}_{\mathrm{IC}}\left(\mathrm{MPa} \cdot \mathrm{m}^{1 / 2}\right)$ & Referência \\
\hline IA * & Colagem & $11,1 \pm 0,2$ & $4,1 \pm 0,2$ & \multirow{5}{*}{$\begin{array}{c}\text { Lazar et al } \\
47 .\end{array}$} \\
\hline $\mathbf{I Z}$ * & Colagem & $10,6 \pm 0,3$ & $5,5 \pm 0,5$ & \\
\hline CAZ * & Prensagem & $10,3 \pm 0,1$ & $5,2 \pm 0,4$ & \\
\hline $\mathbf{P A}$ * & Prensagem & $18,5 \pm 0,5$ & $4,2 \pm 0,8$ & \\
\hline Y-TZP ** & Prensagem & $13,5 \pm 0,3$ & $6,0 \pm 0,2$ & \\
\hline IA & Colagem & $11,0 \pm 0,3$ & $4,4 \pm 0,5$ & \multirow{4}{*}{$\begin{array}{l}\text { Guazzato } \\
\text { et al }{ }^{46,53} \text {. }\end{array}$} \\
\hline IA & Prensagem & $11,0 \pm 1,1$ & $3,6 \pm 0,3$ & \\
\hline $\mathbf{I Z}$ & Colagem & $10,5 \pm 0,2$ & $4,8 \pm 0,5$ & \\
\hline $\mathbf{I Z}$ & Prensagem & $11,0 \pm 0,9$ & $4,9 \pm 0,4$ & \\
\hline AL(i) & & $6,7 \pm 0,4$ & $3,6 \pm 0,3$ & \multirow{6}{*}{$\begin{array}{l}\text { Este } \\
\text { trabalho }\end{array}$} \\
\hline ALZ3Y(i) & & $6,9 \pm 0,1$ & $4,9 \pm 0,7$ & \\
\hline Z3Y(i) & Prensagem & $8,7 \pm 0,1$ & $7,5 \pm 0,2$ & \\
\hline V -AL(m) & & $4,2 \pm 1,8$ & - & \\
\hline V- AL Z3Y(m) & & $2,5 \pm 0,9$ & - & \\
\hline V -Z3Y(m) & & $4,2 \pm 1,0$ & - & \\
\hline
\end{tabular}

* Denominação comercial das cerâmicas

$\mathrm{IA}=$ In-Ceram Alumina (Vita-Zahnfabrik)

$\mathrm{IZ}=$ In-Ceram Zirconia (Vita-Zahnfabrik)

$\mathrm{CAZ}=$ In-Ceram Zirconia (Block Vita-Zahnfabrik)

PA = Procera Al Ceram (Nobel Biocare)

** Y-TZP = Zircônia estabilizada com 3 mol\% de ítria sintetizada experimentalmente por co-precipitação 
Por apresentarem a mesma composição, a amostra $A L(i)$ pode ser comparada à amostra IA, enquanto a amostra ALZ3Y(i) apresenta correspondência com as cerâmicas comerciais IZ e CAZ. Observa-se que apesar dos menores valores de dureza, os valores de tenacidade à fratura das cerâmicas à base de alumina (IA e $A L(i)$ ) são bastante próximos. A mesma semelhança foi observada para a tenacidade das amostras ALZ3Y(i) e seus correspondentes comerciais IZ e CAZ. A análise comparativa entre as amostras preparadas experimentalmente neste trabalho, de diferentes composições, mostra que maiores valores de tenacidade à fratura foram obtidos para as contendo zircônia estabilizada, resultado justificado pelo mecanismo de reforço por transformação. Entretanto, uma avaliação global da microestrutura e aspecto macroscópico mostra que as cerâmicas à base de alumina são mais adequadas para a infiltração da fase vítrea.

Os resultados apresentados na FIG. 5.4.14 referem-se ao teste de citotoxicidade das amostras cerâmicas estudadas, assim como dos controles positivo e negativo. $\mathrm{O}$ índice de citotoxicidade $\left(\mathrm{IC}_{50(\%)}\right)$ corresponde à concentração de extrato do material que provoca a morte de $50 \%$ da população das células. Conforme previsto, o controle positivo (Fenol 0,3\%) produz efeito citotóxico, sendo neste caso $\left.\left(\mathrm{IC}_{(50 \%)}\right)=34,5\right)$. Por sua vez, o controle negativo (pó de alumina) não apresenta efeito citotóxico, $\left(\mathrm{IC}_{(50 \%)}>100\right)$. As amostras cerâmicas avaliadas também não apresentaram efeito citotóxico, resultado este que permite a programação de testes in vivo com o intuito de verificar as interações implantetecido. 


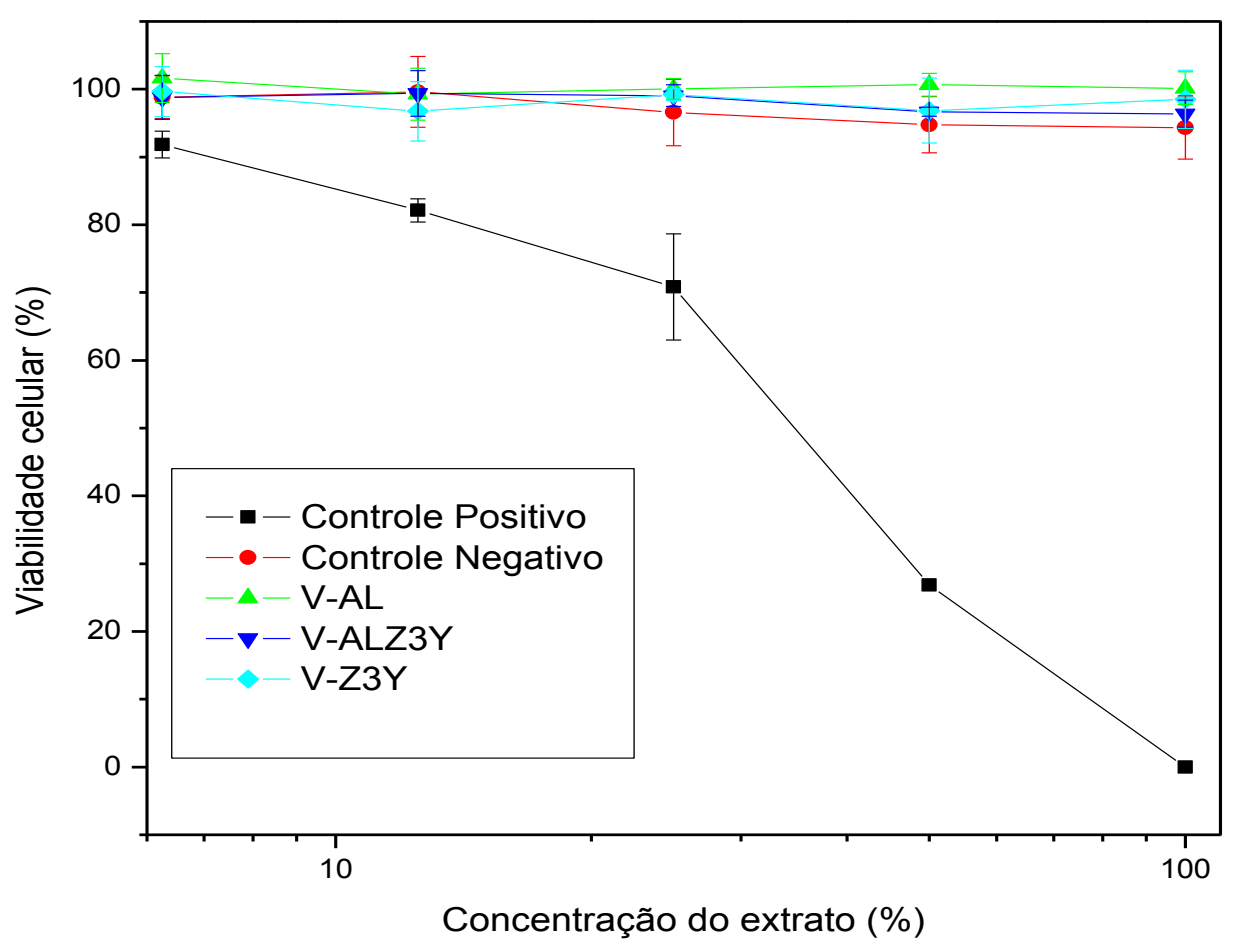

FIGURA 5.4.14 - Curvas de viabilidade celular obtidas no teste de citotoxicidade dos extratos das cerâmicas à base de alumina e zircônia infiltradas com fase vítrea de aluminoborossilicato de lantânio $\mathrm{V}-\mathrm{AL}(\mathrm{m}), \quad \mathrm{V}-\mathrm{ALZ3Y}(\mathrm{m})$ e $\mathrm{V}-\mathrm{Z} 3 \mathrm{Y}(\mathrm{m})$, e controles positivos e negativos. 


\section{CONCLUSÕES}

A rota de síntese por coprecipitação de hidróxidos permitiu a obtenção de pós cerâmicos à base de alumina e zircônia de alta reatividade $\left(66-160 \mathrm{~m}^{2} \cdot \mathrm{g}^{-1}\right)$, quando calcinados a $800^{\circ} \mathrm{C}$ e submetidos à moagem em moinho de bolas. Os pós, embora aglomerados, apresentaram dimensão nanométrica (20 nm). Entretanto, a elevada área de superfície específica dos pós de alumina e compósitos deste óxido não propiciou melhor sinterabilidade das cerâmicas de alumina, quando comparadas às de zircônia estabilizada com $3 \mathrm{~mol} \%$ de ítria, uma vez que ocorre, durante a sinterização, a transformação da fase $\theta$ da alumina para a fase $\alpha$, de menor reatividade $\left(\sim 5 \mathrm{~m}^{2} \cdot \mathrm{g}^{-1}\right)$ e maior tamanho de partícula $(>100 \mathrm{~nm})$

Utilizando-se as condições de calcinação e moagem, acima mencionadas, as cerâmicas à base de alumina atingem densificação em torno de 50\%DT, mesmo após sinterização à $1400^{\circ} \mathrm{C}$, enquanto a densidade das cerâmicas de zircônia estabilizada é de $71 \% \mathrm{DT}$ a $1050^{\circ} \mathrm{C}$. O aumento da temperatura de calcinação dos pós de zircônia de $800^{\circ} \mathrm{C}$ para $950^{\circ} \mathrm{C}$ também possibilita a redução da densidade relativa de $86 \%$ DT para $70 \% \mathrm{DT}$, valor este indicado na literatura para incorporação da fase vítrea de reforço, quando realizada sinterização a $1100^{\circ} \mathrm{C}$.

A incorporação da fase vítrea do pó de aluminoborossilicato de lantânio, por infiltração, em duas etapas, a $1200^{\circ} \mathrm{C}$ por 2 horas, mostrou-se mais eficiente que por mistura de pós seguida de sinterização a $1300^{\circ} \mathrm{C}$ por 2 horas. Este resultado está relacionado à melhor molhabilidade do vidro na matriz cristalina nas condições adotadas no processo de infiltração. 
No caso dos materiais à base de alumina preparados neste trabalho, observou-se maior integridade física, homogeneidade microestrutural e valores de dureza e tenacidade à fratura ( $\left.3,6-4,9 \mathrm{MPa} \cdot \mathrm{m}^{1 / 2}\right)$, comparáveis aos obtidos para as cerâmicas comerciais.

Por sua vez, observou-se maior dificuldade para a infiltração das cerâmicas de zircônia estabilizada, provavelmente devido à maior sinterabilidade desses materiais e conseqüente redução de porosidade na microestrutura. Com base nesses resultados pode-se afirmar que nas condições de síntese e processamento adotados no presente trabalho, as cerâmicas à base de alumina foram mais adequadas para a preparação de infraestruturas dentais contendo fase vítrea de reforço. 


\section{SUGESTÕES PARA TRABALHOS FUTUROS}

- Estudos de degradação das propriedades mecânicas de cerâmicas à base de alumina em solução de saliva artificial, para prever o comportamento deste material quando em função na cavidade bucal.

- Estudo de síntese e processamento cerâmico de compósitos de aluminazircônia co-dopada com céria e ítria, visando minimizar a degradação da cerâmica em meio aquoso.

- Estudos de processamento cerâmico de infraestruturas dentais por colagem de barbotinas.

- Estudo do processamento e etapa de infiltração de cerâmicas à base de alumina preparadas a partir de pós contendo a fase $\alpha$. 


\section{TRABALHOS PUBLICADOS}

DUARTE, D. G.;USSUI, V. ;LAZAR, D. R. R. Processamento cerâmico de infraestrutura porosa à base de alumina e zircônia aplicada em prótese dentária com reforço de fase vítrea. In: 52ํㅡ CONGRESSO BRASILEIRO DE CERÂMICA, 2008, Florianópolis, SC Anais... CD-ROM ref. 13-014.

DUARTE, D. G.; YOSHITO, W.K.; USSUI, V. ;LAZAR, D. R. R. Infiltração de fase vítre em biocerâmicas odontológicas à base de alumina e zircônia. Trabalho a ser apresentado no $53^{\circ}$ CONGRESSO BRASILEIRO DE CERÂMICA, 2009, Guarujá, SP, 07-10 de junho de 2009. 


\section{REFERÊNCIAS BIBLIOGRÁFICAS}

1. CHEVALIER, J.; GREMILLARD, L. Ceramics for medical applications: A Picture for the next 20 years. J. Eur. Ceram. Soc., v.29, p.1245-1255, 2009.

2. CHEVALIER, J. What future for zircônia as a biomaterial? Biomaterials, v.27, p. 535-543, 2006.

3. BAYNE, S.C. Dental biomaterials: where are we and where are we going? $J$ Dent Edu, v.69(5), p. 571-585., 2005.

4. MCLEAN, J.W.; HUGHES, T.H. The reinforcement of dental porcelain with ceramic oxides. Br Dent J, v.119, p. 251-254, 1965.

5. DENRY, I.; KELLY, R. State of art of zirconia for dental applications. Dent Mater, v.24, p.299-307, 2008.

6. DENRY, I. Recent advances in ceramics for dentistry. Crit Rev Oral Biol Med, v.7(2), p.134-143, 1996.

7. KELLY, J.R. Evidence-based decision making: Guide to reading the dental materials literature. J Prosthet Dent, v.95(2), p. 152-160, 2006.

8. MCLEAN, J.W. The alumina reinforced porcelain jacket crown. J Am Dent Assoc, v.75, p.621-628, 1967.

9. DELLA BONA, A.; MECHOLSKY JUNIOR, J.J.; BARRETT, A.A.; GRIGGS, J.A. Characterization of glass-infiltrated alumina-based ceramics. Dent Mater, v.24(11), p. 1568-1574, 2008.

10. APHOLT, W.; BIINDL, A.; LÜTHY, H.; MÖRMANN, W.H. Flexural strength of Cerec 2 machined and jointed InCeram-Alumina and InCeram-Zirconia bars. Dent Mater, v.17, p. 260-267, 2001.

11. CLAUS H. Vita In-Ceram, a new system for producing aluminum oxide crown and bridge substructures. Quintessenz Zahntech, v.16, p. 16-35, 1990.

12. CONRAD, H.J.; SEONG, W-J.; PESUN, I.J. Current ceramic materials and systems with clinical recommendations: a systematic review. J Prosthet Dent, v.98, p. 389-404, 2007.

13. GUAZZATO, M.; ALBAKRY, M.; SWAIN, M.V.; IRONSIDE, J. Mechanical properties of In-Ceram Alumina and In-Ceram Zirconia. Int J Prosthodont, v.15, p. 339-346, 2002. 
14. RAIGRODSCKI, A.J. Contemporary materials and technologies for allceramic fixed partial dentures: a review of the literature. J Prosthet Dent, v.92, p.557-562, 2004.

15. WAGNER, W.C.; CHU T.M. Biaxial flexural strength and indentation fracture toughness of three new dental core ceramics. J Prosthet Dent, v.76, p. 140-146, 1996.

16. SEGHI, R.R.; DENRY I.L.; ROSENTIEL S.F. Relative fracture toughness and hardness of new dental ceramics. J Prosthet Dent, v.74, p. 145-150, 1995.

17. ROSEMBLUM, M.A.; SCHULMAN, A. A review of all-ceramic restorations. J Am Dent Assoc, v.128, p.297-307, 1997.

18. LAWSON S. Environmental degradation of zirconia ceramics. J Eur Ceram Soc, v.15, p.485-502, 1995.

19. GARVIE, R.C.; CHAN, S.K. Stability limits in the monoclinic-tetragonal transformations of zirconia. Physica B, v.150, p.203-211, 1988.

20. SINGH, R.; GILL, R.S.C.; LAWSON, S.; DRANSFIELD, G.P. Sintering, microstructure and mechanical properties of commercial Y-TZPs. J Mater Sci, v.31, p.6055-6062, 1996.

21. RUIZ, L.; READEY, M.J. Effect of heat treatment on grain size, phase assemblage and mechanical properties of 3mol\% Y-TZP. J Am Ceram Soc, v.79(9), p.2331-2340, 1996.

22. DEVILLE, S.; CHEVALIER, J.; FANTOZZI, G.; BARTOLOMÉ, J.F.; REQUENA, J.; MOYA, J.S.; TORRECILLAS, R.; DÍAZ, L.A. Lowtemperature ageing of zirconia-toughened alumina ceramics and its implication in biomedical implants. J. Eur. Ceram. Soc., v. 23, p. 29752982, 2003.

23. GREGORI, G.; BURGER, W.; SERGO, V. Piezo-spectroscopic analysis of the residual stress in zirconia-toughened alumina ceramics: the influence of the tetragonal-to-monoclinic transformation, Mater. Sci. Eng. A, v.271, p. 401-406, 1999.

24. YIN, L.; SONG, X. F.; SONG, T.; HUANG, J. L. An overview of in vitro abrasive finishing \& CAD/CAM of bioceramics in restorative dentistry. Int. J. Machine Tools \& Manufacture, v. 46, p. 1013-1026, 2006.

25. GUAZZATO, M. QUACH, L.; ALBAKRY, M.; SWAIN, M. Influence of surface and heat treatments on the flexural strength of $\mathrm{Y}$-TZP dental ceramic. J. Dent., v. 21(5), p. 454-463, 2005.

26. OKESON, J.P. Tratamento das desordens temporomandibulares e oclusão. $4^{\text {a }}$ Edição, São Paulo, SP.: Artes Médicas, 2000. 
27. MISCH, C.E. Implantes dentários contemporâneos. $2^{\mathrm{a}}$ Edição, São Paulo, SP.: Santos, 2000.

28. ORÉFICE, R.L.; PEREIRA, M.M.; MANSUR, H.S. Biomateriais: Fundamentos e aplicações. $1^{\mathrm{a}}$ Edição, Rio de Janeiro, RJ.: Cultura Médica, 2006.

29. JONES, F.H. Teeth and bones: applications of surface science to dental materials and related biomaterials. Surf. Sci. Rep., v.42, p. 75-205, 2001.

30. SHILLINBURG JUNIOR, H.T.; HOBO, S.; WHITSETT, L.D.; JACOBI, R.; BRACKETT, S.E. Fundamentos de prótese fixa. $3^{a}$ edição, São Paulo, SP.; Quintessence, 1998.

31. KELLY, J. R.; CAMPBELL, S. D. Ceramics in dentistry: historical roots and current perspectives. J Prosthet. Dent., v.75, p. 18-32, 1996.

32. DENRY, I. L. Recent advances in ceramics for dentistry. Crit. Rev. Oral. Biol. Med., v. 7(2), p. 134-143, 1996.

33. QUALTROUGH, A. J. E., PIDDOCK, V. Ceramics update. J. Dent., v. 25(2), p. 91-95, 1997.

34. MCLEAN, J. W. Evolution of dental ceramics in the twentieth century. J. Prosthet. Dent., v. 85, p.61-66, 2001.

35. SANTOS, C.; TEIZEIRA, L.H.P; DAGUANO, J.K.M.F.; ROGERO, S.O.; STRECKER, K.; ELIAS, C.N. Mechanical properties and cytotoxicity of 3YTZP bioceramics reinforced with Al2O3 particles. Ceram Int, v.35, p.709718, 2009.

36. BLATZ, M. B.; SADAN, A.; KERN, M. Resin-ceramic-bonding: a review of the literature. J. Prosthet. Dent., v. 89, p.268-273, 2003.

37. MICHIDA, S. M. A.; VALANDRO, L. F.; YOSHIGA, S. ; ANDREATA FILHO, O. D.; BALDUCCI, I. BOTTINO, M.A. Efeito do tratamento de superfície de uma cerâmica aluminizada infiltrada de vidro sobre a resistência à microtração. J. Appl. Oral Sci., v.11(4), p.361-366, 2003.

38. VALANDRO, L.F.; BOTTINO, M. C.; DELLA BONA, A.; BRESSIANI, A.H.A.; BRESSIANI, J.; BOTTINO, M.A. Estudo da resistência adesiva entre um cimento resinoso e três sistemas cerâmicos odontológicos. In: ANAIS DO 48응 CONGRESSO BRASILEIRO DE CERÂMICA, 28 de junho a $1^{\circ}$ de julho de 2004, Curitiba, PR, ref 16-15.

39. BOTTINO, M.A.; VALANDRO, L.F.; BUSO, L. Prótese metal-free: tratamento da superfície cerâmica pré-cimentação. In: Atualização Clínica em Odontologia, 22ำ CIOSP, São Paulo, Ed. Artes Médicas, p, 369-410, 2004. 
40. GUAZZATO, M.; ALBAKRY, M.; QUACH, L.; SWAIN, M. V. Influence of grinding, sandblasting, polishing and heat treatment on the flexural strength of a glass-infiltrated alumina-reinforced dental ceramic. Biomaterials, v.25, p. 2153-2160, 2004.

41. Vita Zahnfabrik - disponível em: http://www.vitavip.com/en/dentists/materials/products/vita-in-ceram/ Acessado em: 20/02/2009.

42. PICONI, C.; MACCAURO, G. Zirconia as ceramic biomaterial. Biomaterials, v.20, p. 1-25,1999.

43. UO, M.; SJOREN, G.; SUNDH, A.; WATARI, F.; BERGMAN, M.; LERNER, V. Cytotoxicity and bond property of dental ceramics. Dental Mater., v.19, p. 487-492, 2003.

44. LAZAR, D.R.R.; USSUI, V.; BOTTINO, M.C.; LORENZETTI, S.G.; HIGA, O.Z.; PASCHOAL, J.O.A; BRESSIANI, J.C.; BRESSIANI, A.H.A. Efeito de óxidos de terras raras pesadas na biocompatibilidade de cerâmicas Y-TZP. . In: Anais do 49ํㅡㄹ Congresso Brasileiro de Cerâmica, 6-9 de junho de 2005, São Pedro, SP, ref 16-23.

45. GARVIE, R.C.; HANNINK, R.H.; PASCOE, R.T. Ceramic steel? Nature, v.258, p. 703-704, 1975.

46. GUAZZATO, M.; ALBAKRY, M.; RINGER, S. P.; SWAIN, M.V. Strength, fracture toughness and microstructure of a selection of all-ceramic materials. Part II - zirconia based dental ceramics. Dental Mater., v. 20(5), p. 449-456, 2004.

47. LAZAR, D. R. R.; USSUI, V.; BOTTINO, M. C.; VALANDRO, L. F.; BOTTINO, M. A.; PASCHOAL, J. O. A.; BRESSIANI J. C.; BRESSIANI, A. H. A. Caracterização de cerâmicas à base de alumina e zircônia para aplicações odontológicas. In: Anais do 48ํㅡㄹ Congresso Brasileiro de Cerâmica, 28 de junho a $1^{\circ}$ de julho de 2004, Curitiba, PR, ref 16-12.

48. Craig RG, Powers JM. Ceramic metal systems. In: Craig RG. Restorative dental materials. Sant Loouis: Mosby, 1993. p.491-501.

49. ANUSAVICE, K. J. Phillips materiais dentários. Rio de Janeiro: Guanabara Koogan. 1998.

50. DE SOUZA, C.F. Resistência à Fratura de Subestruturas para Próteses Parciais Fixas Posteriores de Zircônia Densa sob Testes de Fadiga Cíclica. 2007. Dissertação (Mestrado) - Universidade Federal do Rio de Janeiro, COOPE, Rio de Janeiro.

51. KELLY, J.R. Dental ceramics: current thinking and trends. Dent Clin $\mathbf{N} \mathbf{A m}$, v.48, p.513-530, 2004. 
52. CONRAD, H.J.; SEONG, W-J; PESUN, I.J. Current ceramic materials and systems with clinical recommendations: A systematic review. J Prosthet Dent, v.98, p.389-404, 2007.

53. GUAZZATO, M.;ALBAKRY, M.; Ringer, S.P.; Swain, M.V. Strength, fracture toughness and microstructure of a selection of all-ceramic materials. Part I. Pressable and alumina glass-infiltrated ceramics. Dent Mater., v.20, p.441448, 2004.

54. Jorgenson MW, Goodkind RJ. Spectrophotometric study of five porcelain shades relative to the dimensions of color, porcelain thickness, and repeated firing. J Prosthet Dent, v.42, p.96-105, 1979.

55. McLean JW, Hughes TH. The reinforcement of dental porcelain with ceramic oxides. Br Dent J 1965;119:251-67 apud McLean JW. Evolution of dental ceramics in the twentieth century J Prosthet Dent, v.85, p. 85:61-6, 2001.

56. Dörre E, Hübner H. Alumina - Processing, Properties and Applications. Berlim, Springer-Verlag, 1984.

57. Garcia RHL. Síntese e processamento de compósitos zircônia-alumina para aplicação como eletrólito em células de óxido sólido. 2007 Dissertação (Mestrado) - Instituto de Pesquisas Energéticas e Nucleares, São Paulo.

58. FARNWORTH, F.; JONES, S.L.; MCALPINE, I. The production, properties and use of zircônia chemical. In: THOMPSON, R. (Ed) Speciality inorganic chemicals. London: Royal Soc. Of Chemistry, 1980, p. 249-284.

59. Heuer AH, Lange FF, Swain MV, Evans AG. Transformation toughening: an overview. J Am Ceram Soc, v.69, p. i-iv, 1986.

60. GREEN, D.J.; HANNINK, R.H.J.; SWAIN, M.V. Transformation toughening of ceramics. Boca Raton, Fla.: CRC, 1989.

61. MENEZES, C.A.B. Estudo da influência do teor de elementos de terras raras leves nas cerâmicas de zircônia-céria-ítria. 2001. Tese (Doutorado) - Instituto de Pesquisas Energéticas e Nucleares, São Paulo.

62. KINGERY, W.D.; BOWEN, H.K.; UHLMANN, D.R. Introduction to ceramics. Second Edition, New York, NY.: John Wiley \& Sons, 1976.

63. STEVENS, R. Zirconia and zircônia ceramics. London, UK.: Magnesium Elektron, 1986.

64. KUMAR, A.S.; DURAI, A.R.; SORNAKUMAR, T. Development of yttria and ceria toughned alumina composite for cutting tool application. Int $\boldsymbol{J}$ Refrac Metals \& Hard Mater, v.25, p.214-219, 2007. 
65. SINGH, R.; GILL R.S.C.; LAWSON S.; DRANSFIELD G.P. Sintering, microstructure and mechanical properties of commercial Y-TZPs. J Mater Sci, v.31, p.6055-6062, 1996.

66. CHEVALIER J.; DEVILLE S.; MÜNCH E.; JULLIAN R.; LAIR F. Critical effect of cubic phase on aging in 3mol\% yttria-stabilized zirconia ceramics for hip replacement prosthesis. Biomaterials, v.25, p.5539-5545, 2004.

67. GUAZZATO, M.; PROOS, K.; QUACH, L.; SWAIN MV. Strength, reliability and mode of fracture of bilayered porcelain/zirconia (Y-TZP) dental ceramics. Biomaterials, v.25, p.5045-5052, 2004.

68. SCHERRER, S.S.; DENRY, I.L.; WISKOTT, H.W.A. Comparison of three fracture toughness testing techniques using a dental glass and a dental ceramic. Dent Mater, v.14, p.246-255, 1998.

69. SCOTT, H.G. Phase relationships in the zirconia-yttria system. J Mater Sci, 1975;10:1527-35.

70. RODRÍGuEZ, A.D.; GARCÍA, D.G.; MARTíN, C.L.; BERNABÉ, A.M. Influence of yttrium segregation at grain boundaries in the superplasticity of yttria tetragonal zirconia polycrystals. J Eur Ceram Soc, v.23, p.2969-2973, 2003.

71. DEVILLE, S.; CHEVALIER, J.; FANTOZZI, G.; BARTOLOME, J.; REQUENA, J.; MOYA J. Low-temperature ageing of zirconia-toughened alumina ceramics and its implication in biomedical implants. $J$ Eur Ceram Soc, v.23, p.2975-2982, 2003.

72. GUTKNECHT, D.; CHEVALIER, J.; GARNIER, V.; FANTOZZI, G. Key role of processing to avoid low temperature ageing in alumina zirconia composites for orthopaedic application. J Eur Ceram Soc, v.27, p.15471552, 2007.

73. KOSMAC, T.; OBLAK, C.; MARION, L. The effects of dental grinding and sandblasting on ageing and fatigue behavior of dental zirconia (Y-TZP) ceramics. J Eur Ceram Soc, v.28, p.1085-1090, 2008.

74. NETTLESHIP, I.; STEVENS, R. Tetragonal Zirconia Polycrystal (TZP) - A Review. Int J High Tech Ceram, v.3, p.1-32, 1987.

75. SANTOS, C.; SOUZA, R.C.; ALMEIDA, N.; ALMEIDA, F.A.; SILVA, R.R.F.; FERNANDES, M.H.F.V. Toughened $\mathrm{ZrO}_{2}$ ceramics sintered with $\mathrm{La}_{2} \mathrm{O}_{3}$-rich glass as additive. J, Mater. Proc. Technol. V.200, p.126-132, 2008.

76. GUO, X. On the degradation of zirconia ceramics during low-temperature annealing in water or water vapor. J Phys Chem Solids, v.60, p.539-546, 1999. 
77. MENEZES, C.A.B.; LAZAR, D.R.R.; USSUI, V.; LIMA, N.B.; PASCHOAL, J.O.A. Influence of dopant content on thermal degradation of $\mathrm{ZrO}_{2}-\mathrm{CeO}_{2}$ $\mathrm{Y}_{2} \mathrm{O}_{3}$ ceramics. Key Eng. Mater., v.189-91, p.192-197, 2001.

78. MENEZES, C.A.B.; LAZAR, D.R.R.; USSUI, V.; LIMA, N.B.; PASCHOAL, J.O.A. The role of light rare earth on thermal degradation behaviour of $\mathrm{ZrO}_{2}-$ $\mathrm{CeO}_{2}-\mathrm{Y}_{2} \mathrm{O}_{3}$ ceramics. Mater. Sci. Forum, v.416-418, p.573-578, 2003.

79. ROSENBLUM, M.A.; SCHULMAN A. A review of all-ceramic restorations. $J$ Am Dent Assoc, v.3, p.297-307, 1997.

80. SHENG, X.; XU, H.; JIN, Z.; WANG, Y. Preparation of glass-infiltrated 3yTZP/Al ${ }_{2} \mathrm{O}_{3} /$ glass composites. Mater Letter, v.58, p.1750-1753, 2004.

81. CHOI, S.R.; BANSAL, N.P. Mechanical behavior of zirconia/alumina composites. Ceram Int, v.341, p.39-46, 2005.

82. TSUKUMA, K.; SHIMADA, M. Strength, fracture toughness and Vickers hardness of $\mathrm{CeO}_{2}$-stabilized tetragonal $\mathrm{ZrO}_{2}$ polycrystals (Ce-TZP). J Mater Sci, v.20, p.1178-1184, 1985.

83. DUH, J.G.; LEE, M.Y. Fabrication and sinterability in $\mathrm{Y}_{2} \mathrm{O}_{3}-\mathrm{CeO}_{2}-\mathrm{ZrO}_{2}$. $J$ Mater Sci, v.24, p.4467-4474, 1989.

84. DUARTE, D.G.; BOTTINO, M.A.; LEITE, F.P.P.; VALANDRO, L.F.; KIMPARA, E.T. Avaliação da resistência de união entre uma cerâmica prensada e dois cimentos resinosos. Rev Odon Unesp, v.35(2), p.119-124, 2006.

85. LU, R.; HARCOURT, J.K.; TYAS, M.J.; ALEXANDER, B. An investigation of composite resin/porcelain interface. Aust Dent J, v.37(1), p. 12-19, 1992.

86. AIDA, M.; HAYAKAWA, T.; MIZUKAWA, K. Adhesion of composite to porcelain with various surface conditions. J Prosthet Dent, v.73(5), p.464470, 1995.

87. HAYAKAWA, T.; HAYAKAWA, T.; HORIE, K.; AIDA, M.; KANAYA, H.; KOBAYASHI, T.; MURATA Y. The influence of surface conditions and silane agents on the bond of resin to dental porcelain. Dent Mater, v.8, p.238-240, 1992.

88. AMARAL, R.; ÖZCAN, M.; BOTTINO, M.A.; VALANDRO, L.F. Microtensile bond strength of a resin cement to glass infiltrated zirconia-reinforced ceramic: The effect of surface conditioning. Dental Mater, v.22, p.283-290, 2006.

89. VALANDRO, L.F.; DELLA BONA, A.; BOTTINO, M.A.; NEISSER, M.P. The effect of ceramic surface treatment on bonding to densely sintered alumina ceramic. J Prosthet Dent, v.93, p.253-259, 2005. 
90. AWLIYA, W.; AWLIYA, W.; ODÉN, A.; YAMAN, P.; DENNISON, J.B.; RAZZOOG, M.E. Shear bond strength of resin cement to densely sintered high-purity alumina with various surface conditions. Acta Odontol Scand, v.56, p. 913, 1998.

91. BLIXT, M.; ADAMCZAK, E.; LINDÉN, L.A.; ODÉN, A.; ARVIDSON, K. Bonding to densely sintered alumina surfaces: effect of sandblasting and silica coating on shear bond strength of luting cements. Int J Prosthodont, v.13, p.221226, 2000.

92. TEUFER, G. The Crystal structure of tetragonal $\mathrm{ZrO}_{2}$. Acta Crystallogr. v.15(11), p.1187, 1962.

93. GARCIA, R. H. L. ; USSUI, V. ; LIMA, N. B. ; LAZAR, D. R. R. 3Y-TZP$\mathrm{Al}_{2} \mathrm{O}_{3}$ powders synthesized by the coprecipitation route. Mater. Sci. Forum, v. 530-531, p. 677-682, 2006.

94. IOST, A.; BIGOT, R. Indentation size effect: reality or artefact? J. Mater. Sci., v.31, p.3573-3577, 1996.

95. PONTON, C.B.; RAWLINGS, R.D. Vickers indentation fracture toughness test. Part 1 - Review of literature and formulation of standardised indentation toughness equations. Mater. Sci. Technol., v.5, p.865-872, 1989.

96. PONTON, C.B.; RAWLINGS, R.D. Vickers indentation fracture toughness test. Part 2 - Application and critical evaluation of standardised indentation toughness equations. Mater. Sci. Technol., v.5, p.961-976, 1989.

97. ISO document 10993-5. Biological evaluation of medical devices, Part 5, Tests for cytotoxicity: in vitro methods, 1992.

98. KOMEYA, K.; MATSUI, M. High temperature engineering ceramics. In: CAHN, R. W.; HAASEN, P.; KRAMER, E. J. (Eds) Materials Science and Technology. A comprehensive treatment $v$. 11: Structure and properties of ceramics. New York, N. Y.: VCH, 1994, p. 517-565.

99. BIGHETTI, C. M. M.; SANTOS, C.; TAGUCHI, S.P. Estudo da molhabilidade de um vidro rico em lantânia, em zircônia e zircônia-alumina. In: $18^{\circ}$ CBECIMAT - CONGRESSO BRASILEIRO DE ENGENHARIA E CIÊNCIA DOS MATERIAIS, 2008, Porto de Galinhas, PE Anais... v.1, p.114-125. CD-ROM ref 101-023.

100. ACCAR, W. Materiais Cerâmicos - Caracterização e Aplicações. Natal, RN: Edufrn, 2006 